Review

\title{
Electrocoagulation and advanced electrocoagulation processes: A general review about the fundamentals, emerging applications and its association with other technologies
}

\author{
Sergi Garcia-Segura ${ }^{\mathrm{a}}$, Maria Maesia S.G. Eiband ${ }^{\mathrm{a}}$, Jailson Vieira de Melo ${ }^{\mathrm{a}}$, \\ Carlos Alberto Martínez-Huitle ${ }^{\mathrm{a}, \mathrm{b}, *}$ \\ ${ }^{\text {a }}$ Laboratório de Eletroquímica Ambiental e Aplicada (LEAA), Institute of Chemistry, Federal University of Rio Grande do Norte, Lagoa Nova, CEP $59078-970$ Natal, RN, \\ Brazil \\ b Unesp, National Institute for Alternative Technologies of Detection, Toxicological Evaluation and Removal of Micropollutants and Radioactives (INCT-DATREM), \\ Institute of Chemistry, P.O. Box 355, 14800-900 Araraquara, SP, Brazil.
}

\section{A R T I C L E I N F O}

\section{Keywords:}

Electrocoagulation

Electroflotation

Electrochemical reactor

Wastewater treatment

\begin{abstract}
A B S T R A C T
The electrocoagulation (EC) process is an electrochemical means of introducing coagulants and removing suspended solids, colloidal material, and metals, as well as other dissolved solids from water and wastewaters. EC process has been successfully employed in removing pollutants, pesticides, and radionuclides. This process also removes harmful microorganisms. More often during EC operation, direct current is applied and electrode plates are sacrificed (dissolved into solution). The electrodissolution causes an increased metal concentration in the solution that finally precipitates as oxides and hydroxides. Due to the process design and low cost material, the EC process is widely accepted over other physicochemical processes. In this frame, this paper presents a general review of efficient EC technologies developed to remove organic and inorganic matter from wastewaters for environmental protection. Fundamentals and main applications of EC as well as progress of emerging EC treatments are reported. The influence of iron or aluminum anode on depollution of synthetic or real effluents is explained. The advantages of EC mechanisms with $\mathrm{Al}$ and Fe electrodes are extensively discussed. There are presented the advanced EC processes with in situ generation of hydroxyl radical. The importance of the operating parameters for efficient application of the EC process as well as the combination of this electrochemical technology with electroanalysis techniques and other technologies are commented.
\end{abstract}

\section{Introduction}

The limitation of hydric sources and the environmental impact to the planet health of polluted wastewater is nowadays an undeniable worldwide concern. Then, water pollution and water recycling are one of the greatest environmental challenges of XXI century [1]. In this context, water treatment technologies emerge as the most direct solution to reduce the pollution impact in water bodies. Centralized water and wastewater treatment plants try to deal with this environmental issue. Among all the water technologies, physico-chemical processes are the most used technologies because these have been known and applied since centuries to make water drinkable for human intake [2]. However, nowadays due to the technological development and the industrial activity the pollutants contained in waters are completely different from those of ancient times. Thus, the water treatment technologies have been a hot topic of research to remediate the emergent pollution.

In this context, EC is an electrochemical technology with wide range of application that can reduce effectively the presence of several pollutants in water from heavy metals until persistent organic pollutants. During the last decades this promising technology has been extensively studied to understand its principles, parameters of influence, removal mechanisms and to evidence its applications [3-9]. However, these authoritative reviews summarized and discussed specific cases and no mention about the emerging EC technologies is done (e.g.: photoEC, peroxo EC and coupled EC approaches). For this reason, this review aims to be a reference document that summarizes the fundamentals of EC technologies including, for first time, the advanced EC with in situ generation of oxidant species to improve the pollutants removal efficacy as well as the coupling of on-line electroanalytical technologies to

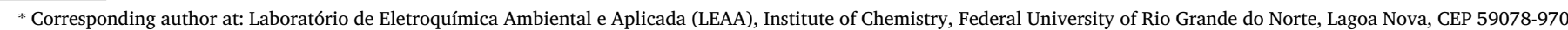
Natal, RN, Brazil.

E-mail address: carlosmh@quimica.ufrn.br (C.A. Martínez-Huitle). 


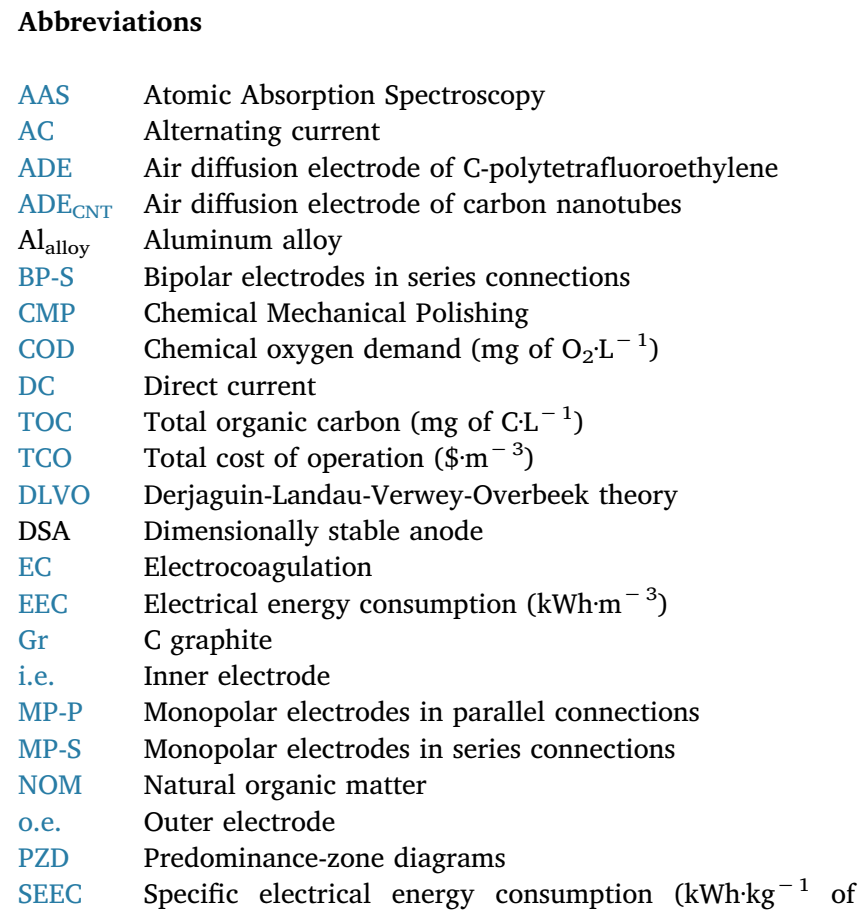
SEECP specific electrical energy consumption per pollutant mass (kWh $\mathrm{kg}^{-1}$ of pollutant)
SS Stainless steel
St Steel
$\mathrm{St}_{\text {wool }} \quad$ Steel wool
UV Ultraviolet
Y Percentage of pollutant removed

Symbols

E $\quad$ Electrical potential (V)

F Faraday constant $\left(96,487 \mathrm{C} \mathrm{mol}^{-1}\right)$

I Current (A)

j Current density $\left(\mathrm{mA} \mathrm{cm}^{-2}\right)$

$\mathrm{M}_{\mathrm{pol}} \quad$ Molecular weight of pollutant $\left(\mathrm{g} \mathrm{mol}^{-1}\right)$

$\mathrm{M}_{\mathrm{W}} \quad$ Molecular weight $\left(\mathrm{g} \mathrm{mol}^{-1}\right)$

$\mathrm{n} \quad$ Number of electrons

R Electrical resistance $(\Omega)$

$t_{\mathrm{EC}} \quad$ Time of electrocoagulation treatment (h)

$\mathrm{V}_{\mathrm{S}} \quad$ Volume treated $\left(\mathrm{m}^{3}\right)$

$\Delta \mathrm{m}_{\mathrm{exp}} \quad$ Experimental electrodic mass loss

$\Delta \mathrm{m}_{\text {theo }} \quad$ Theoretical electrodic mass loss

$\varphi \quad$ Efficiency of anodes dissolution follow the pollutants abatement. Also, the combination of EC with membrane filtration has been introduced. Furthermore, a comprehensive and general review about the works reported in the literature has been done in order to become a communication of researchers' experience to stimulate the launch of novel and revolutionary ideas to improve the process performance and future applications.

\section{Fundamentals}

Coagulation is a traditional physico-chemical treatment via phase separation for the decontamination of wastewaters before discharge to the environment [9]. EC is directly related to conventional coagulation process, which has been used as a method (early as $2000 \mathrm{BCE}$ ) for water clarification and potabilization [2] and nowadays, it is still extensively used [10].

The process is based on the formation and aggregation of a colloidal system and its further coagulation enhanced by the use of the coagulating agents. Metallic and organic pollutants are separated from the aqueous phase by their precipitation with the coagula and subsequently removed from the treated water [11,12]. The aggregates formation is explained by the Derjaguin-Landau-Verwey-Overbeek (DLVO) theory where it is assumed that the formation of an aggregate depends on the interaction forces by the sum of Van der Waals and double layer forces [13]. The simplest consideration is the symmetric system (homo-aggregation) where the double layer force is repulsive and the Van der Waals forces attractive; then, the attractive force has to overcome the repulsive force in order to form the aggregate. Meanwhile, hetero-aggregation systems are from far more complex due to the dual character of the double layer forces which could be attractive, repulsive or both effects simultaneously (while Van der Waals forces are normally attractive).

Nevertheless, DLVO theory cannot totally explain the coagulation phenomena because in this complex system other interactive forces than electrostatic repulsion (e.g.: hydration, hydrophobic interactions and so on) are involved on the colloids stabilization [14,15].

In coagulation water treatment process, the addition of coagulating agents (such as $\mathrm{Fe}^{3+}$ or $\mathrm{Al}^{3+}$ salts) favors the formation of pollutant aggregates [16], their coagulation and after that, their physical separation from water by precipitation or flotation [17,18], allowing the removal of metal and organic pollutants from water by different coagulation mechanisms, which will be discussed in the subsections below. By adding coagulant agents into water, in general, a decrease on the distance of the electrical double-layer is promoted (due to the counter-ions (coagulants) concentration increase in solution, which reduces the electrostatic repulsion by the pollutants charge shielding $[13,19])$, diminishing the surface potential and the energy barrier required to form easily the aggregate.

Considering the EC approach, similar effects to conventional coagulation can be produced $[20,21]$. This technique uses a current to dissolve $\mathrm{Fe}, \mathrm{Al}$ or other metals as sacrificial anodes immersed in the polluted water. The electrodisolution promotes an increase on the metal ions in solution or their complexed species with hydroxide ion depending on the $\mathrm{pH}$ conditions and the sacrificial anode used [22-24]. These species act as coagulants or destabilization agents, helping to separate pollutants from the wastewaters [25].

In general, specific steps take place during an EC treatment [26-28]:

(i) Electrodic reactions that produce metal ions from anodes electrodissolution, and $\mathrm{H}_{2}$ gas evolution at the cathode,

(ii) Destabilization of the pollutants, particulate suspension and breaking emulsions,

(iii) Formation of aggregates of the destabilized phases and its coagulation in the wastewater as flocs,

(iv) Removal of coagulated pollutants by sedimentation or by electroflotation by evolved $\mathrm{H}_{2}$ (electroflotation can be used to disperse the coagulated particles via the bubbles of $\mathrm{H}_{2}$ gas produced at the cathode from water reduction reaction, transporting the solids to the top of the solution),

(v) Electrochemical and chemical reactions promoting the cathodic reduction of organic impurities and metal ions onto the cathode surface.

Considering the features of EC approach, it presents many advantages to the conventional physico-chemical treatment of coagulation. The main advantages that have been reported by several authors $[20,29,30]$ are listed below: 
(i) More effective and rapid organic matter separation than in coagulation,

(ii) $\mathrm{pH}$ control is not necessary, except for extreme values,

(iii) Coagulants are directly electrogenerated, thus chloride or sulfate ions are not added to the solution and consequently, eliminating competitive anions; allowing a maximum adsorptive removal,

(iv) The highly-pure electrogenerated coagulant improves the pollutants removal, then, a smaller amount of chemicals is required,

(v) A direct consequence of (iv) is the lower amount of sludge produced,

(vi) The operating costs are much lower than conventional technologies.

However, this method presents some major disadvantages [31,32] related to:

(i) The possible anode passivation or/and sludge deposition on the electrodes that can inhibit the electrolytic process in continuous operation mode,

(ii) Even though lower amount of sludge is produced in comparison with coagulation, the treated effluents still present high concentrations of iron and aluminum ions in the effluent that avoid their direct release to the environment. Thus, a post-treatment to reduce the metallic ions concentration after the electrochemical process is required in order to attend the environmental legislations,

(iii) The sacrificial anodes are consumed and must be replaced periodically.

(iv) Deposition of hydroxides of calcium, magnesium, etc., onto the cathode, avoiding the release of $\mathrm{H}_{2}$ and the pass of current, when using actual wastewaters. This can solved using alternate current with same anode and cathode materials.

\subsection{Sacrificial anode materials for electrocoagulation}

In this subsection will be presented the main materials used as sacrificial anodes in EC. The anodic dissolution of the anodes releases in the water the coagulants responsibles of the pollutants removal.

\subsubsection{Iron and steel anodes}

When an iron, steel (St) or stainless steel (SS) anode is used in EC, $\mathrm{Fe}^{2+}$ is dissolved in the treated wastewater by $\mathrm{Fe}$ oxidation at the anode, as follows $[33,34]$ :

$\mathrm{Fe} \rightarrow \mathrm{Fe}^{2+}+2 \mathrm{e}^{-}$

Meanwhile, hydroxide ion and $\mathrm{H}_{2}$ gas are generated at the cathode from the water reduction reaction:

$2 \mathrm{H}_{2} \mathrm{O}+2 \mathrm{e}^{-} \rightarrow 2 \mathrm{OH}^{-}+\mathrm{H}_{2}(\mathrm{~g})$

Significant $\mathrm{OH}^{-}$production from reaction (2) causes an increase in $\mathrm{pH}$ during electrolysis leading to the formation of different iron hydroxocomplexes in solution. Fig. 1 presents the predominance-zone diagrams (PZD) of stability of iron(II) and iron(III) and their hydrocomplexes as a function of $\mathrm{pH}[18,35]$, which is a control parameter of coagulation in EC. As can be deduced from Fig. 1a, insoluble $\mathrm{Fe}(\mathrm{OH})_{2}$ precipitates at $\mathrm{pH}>5.5$ and remains in equilibrium with $\mathrm{Fe}^{2+}$ up to $\mathrm{pH} 9.5$ or with other monomeric species such as $\mathrm{Fe}(\mathrm{OH})^{+}$from $\mathrm{pH} 9.5$ up to 11.4 and $\mathrm{Fe}(\mathrm{OH})_{3}{ }^{-}$from 11.8 to 14.0 . The formation of insoluble $\mathrm{Fe}(\mathrm{OH})_{2}$, which favors the coagula precipitation, can be written as [20]:

$\mathrm{Fe}^{2+}+2 \mathrm{OH}^{-} \rightarrow \mathrm{Fe}(\mathrm{OH})_{2}(\mathrm{~s})$

and the overall reaction for the electrolytic process from the sequence of reactions (1)-(3) is:

$\mathrm{Fe}+2 \mathrm{H}_{2} \mathrm{O} \rightarrow \mathrm{Fe}(\mathrm{OH})_{2}(\mathrm{~s})+\mathrm{H}_{2}(\mathrm{~g})$

Even though iron(II) species can generate coagulates, the iron(III) species are those that present higher charge density favoring even more the coagulation-flocculation process. This performance is related to an efficient decrease on the electrical double-layer by major charge valence of the metal ions used as coagulant. Thus, the higher charge valence the coagulant ion carries, the less the dosage required to obtain the same results $[13,14,36]$.

In the case of iron(III), this species could be directly electrogenerated from the sacrificial anode depending on the voltage applied by direct charge transfer (5) involving the anode electrodissolution. Besides, Fe(II) could be easily oxidized by reaction (6) to insoluble Fe $(\mathrm{OH})_{3}$ in the presence of $\mathrm{O}_{2}$, which is commonly dissolved in water $[9,20,37]$ :

$\mathrm{Fe} \rightarrow \mathrm{Fe}^{3+}+3 \mathrm{e}^{-}$

$4 \mathrm{Fe}^{2+}+10 \mathrm{H}_{2} \mathrm{O}+\mathrm{O}_{2}(\mathrm{~g}) \rightarrow 4 \mathrm{Fe}(\mathrm{OH})_{3}(\mathrm{~s})+8 \mathrm{H}^{+}$

where protons can be neutralized with the $\mathrm{OH}^{-}$produced in reaction (2) or directly reduced to $\mathrm{H}_{2}$ gas at the cathode by means of reaction (7):

$2 \mathrm{H}^{+}+2 \mathrm{e}^{-} \rightarrow 2 \mathrm{H}_{2}(\mathrm{~g})$

The PZD of iron(III) shown in Fig. 1b evidences that $\mathrm{Fe}(\mathrm{OH})_{3}$ coagulates since $\mathrm{pH}>1.0$. Then, this predominant precipitated species is in equilibrium with different soluble monomeric species as a function of the $\mathrm{pH}$ range [35]. Thus, $\mathrm{Fe}(\mathrm{OH})_{3}$ is in equilibrium with $\mathrm{Fe}^{3+}$ up to pH 2.0, $\mathrm{Fe}(\mathrm{OH})^{2+}$ from 2.0 up to $3.8, \mathrm{Fe}(\mathrm{OH})_{2}{ }^{+}$from 3.8 up to 6.2 and $\mathrm{Fe}(\mathrm{OH})_{4}{ }^{-}$from 9.6 and so on. It is important to indicate that in the diagram, $\mathrm{Fe}(\mathrm{OH})_{3}$ is the unique species present in solution in the range of $\mathrm{pH}$ between 6.2 and 9.6. Besides, the complexes have a significant tendency to polymerize as $\mathrm{Fe}_{2}(\mathrm{OH})_{2}{ }^{4+}$ and $\mathrm{Fe}_{2}(\mathrm{OH})_{4}{ }^{2+}$ complexes between $\mathrm{pH}$ 3.5-7.0 [38] depending on the applied current density and

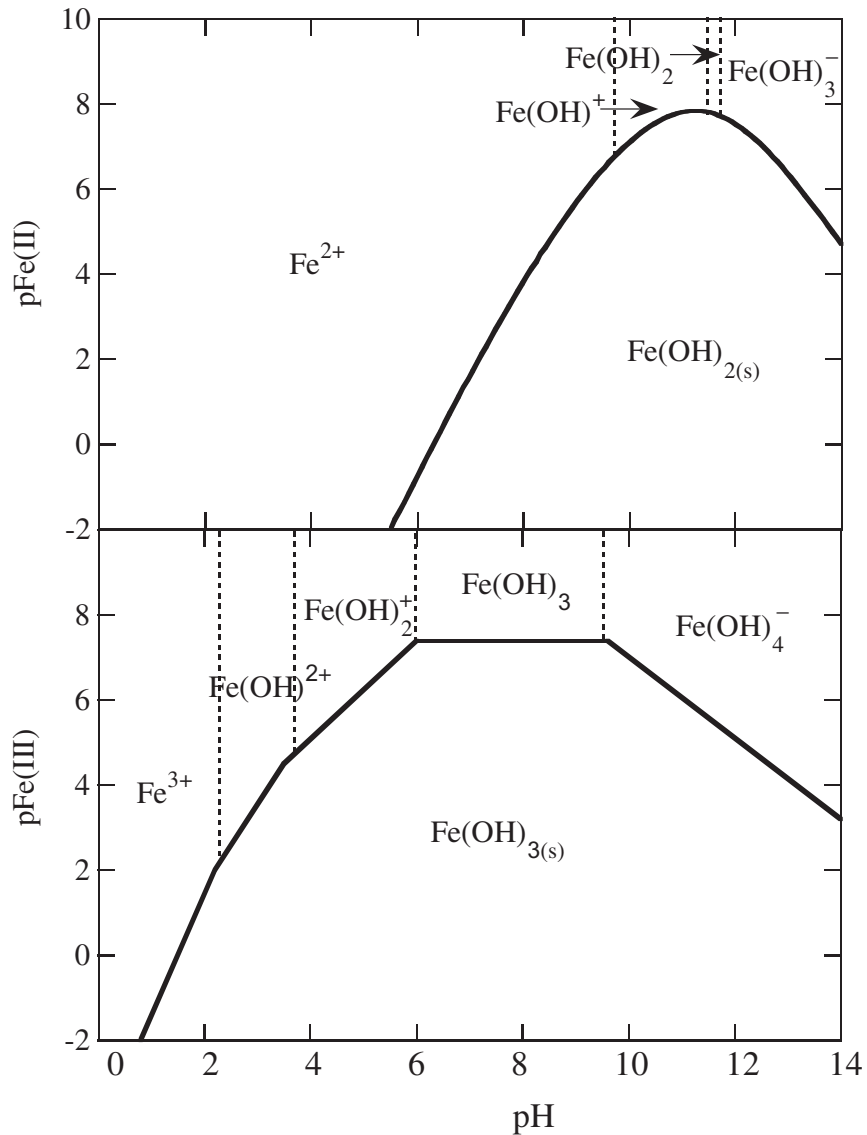

Fig. 1. Predominance-zone diagrams for iron species in aqueous solution in function of pH. Iron species: (a) Fe(II), (b) Fe (III) 
the electrolysis time. All these species with different protecting charge and electrostatic attraction favor the coagulum formation/precipitation, in major or less extent, depending on the pollutant characteristics. However, among all the iron(III) species, $\mathrm{Fe}(\mathrm{OH})_{3}$ is considered to be the preferred coagulant agent and the main responsible of pollutants removal.

\subsubsection{Aluminum anode}

In the case of $\mathrm{EC}$ with $\mathrm{Al}$, the anodic reaction (8) leads soluble $\mathrm{Al}^{3+}$ $[39,40]$ while the cathodic reaction produces hydroxide ion and $\mathrm{H}_{2}$ gas by reaction (2).

$\mathrm{Al} \rightarrow \mathrm{Al}^{3+}+3 \mathrm{e}^{-}$

Aluminum ions in the aqueous medium present a complex equilibrium with different monomeric species such as $\mathrm{Al}(\mathrm{OH})^{2+}, \mathrm{Al}(\mathrm{OH})_{2}{ }^{+}$, $\mathrm{Al}(\mathrm{OH})_{3}$ and $\mathrm{Al}(\mathrm{OH})_{4}{ }^{-}$depending on the $\mathrm{pH}$ conditions [41], as it is shown in the PZD of Fig. 2 [42]. Several authors have reported the polymerization of the former monomeric species as $\mathrm{Al}_{2}(\mathrm{OH})_{2}{ }^{4+}$, $\mathrm{Al}_{6}(\mathrm{OH})_{15}{ }^{3+}, \quad \mathrm{Al}_{7}(\mathrm{OH})_{17}{ }^{4+}, \quad \mathrm{Al}_{8}(\mathrm{OH})_{20}{ }^{4+}, \quad \mathrm{Al}_{13} \mathrm{O}_{4}(\mathrm{OH})_{24}{ }^{7+}$ and $\mathrm{Al}_{13}(\mathrm{OH})_{34}{ }^{5+}[40,42,43]$. However, the main responsible of the floccules and aggregates formation is $\mathrm{Al}(\mathrm{OH})_{3}$, which is formed by complex precipitation mechanisms from the soluble monomeric and polymeric cations. Being the overall reaction (9) in the bulk:

$\mathrm{Al}+3 \mathrm{H}_{2} \mathrm{O} \rightarrow \mathrm{Al}(\mathrm{OH})_{3}(\mathrm{~s})+3 / 2 \mathrm{H}_{2}(\mathrm{~g})$

\subsection{Other anodes}

Although iron/steel and aluminum anodes are the preferred sacrificial anodes used in EC, some works have proposed the use of alternative anodic materials such $\mathrm{Zn}$ and $\mathrm{Mg}$ anodes [44-46]. The principles are the same that the stated formerly for $\mathrm{Al}$ and $\mathrm{Fe}$ anodes, consisting on the anodic dissolution of the anodes by reactions (10) and (11) for $\mathrm{Zn}$ and $\mathrm{Mg}$, respectively. The ions generated undergo further the formation of their corresponding hydroxides depending on the $\mathrm{pH} . \mathrm{Zn}(\mathrm{OH})_{2}$ and $\mathrm{Mg}(\mathrm{OH})_{2}$ formed by Eqs. (12) and (13) are the main species that cause the pollutants coagulation [24].

$\mathrm{Zn} \rightarrow \mathrm{Zn}^{2+}+2 \mathrm{e}^{-}$

$\mathrm{Mg} \rightarrow \mathrm{Mg}^{2+}+2 \mathrm{e}^{-}$

$\mathrm{Zn}^{2+}+2 \mathrm{H}_{2} \mathrm{O} \rightarrow \mathrm{Zn}(\mathrm{OH})_{2}(\mathrm{~s})+2 \mathrm{H}^{+}$

$\mathrm{Mg}^{2+}+2 \mathrm{H}_{2} \mathrm{O} \rightarrow \mathrm{Mg}(\mathrm{OH})_{2}(\mathrm{~s})+2 \mathrm{H}^{+}$

In the case of aluminum and iron ions, these present a major charge valence than that for zinc and magnesium ions, which favors the coagulation process with lower coagulant concentration. However, the evaluation of other coagulants electrochemically generated is related to the residual concentrations of the coagulants that remain in the water after the treatment. For instance, United States Environmental Protection Agency (USEPA) suggests limiting concentrations for aluminum of $0.2 \mathrm{mg} / \mathrm{L}$ to avoid health problems; while for magnesium, $30.0 \mathrm{mg} / \mathrm{L}$ is the limit established [45].

\subsection{Pollutants removal mechanisms}

The mechanisms involved in EC are not clearly understood yet [27], but during the last decade several researchers [47-49] have tried to elucidate the mechanisms involved during the removal of pollutants. This subsection presents a brief overview to give an insight on the most important mechanisms considered during EC for removing pollutants from water, which are summarized in Fig. 3. These are classified into two main groups:

\subsubsection{Heavy metals removal}

Heavy metals are mainly removed by EC by two mechanisms: (i) surface complexation and (ii) electrostatic attraction. But, it is important to consider that, the insoluble flocs of the coagulant metalhydroxide are produced independently on the removal mechanism [37]. Meanwhile, other mechanisms are feasible, such as (iii) adsorption and (iv) direct precipitation by the formation of the pollutant metal hydroxides.

The complexation mechanism considers that the heavy metal can act as a ligand to form a complexation bond to the hydrous moiety of the coagulant floc (mainly $\mathrm{Fe}(\mathrm{OH})_{3}$ or $\mathrm{Al}(\mathrm{OH})_{3}$ ) yielding a surface complex. Subsequently, the formation of these complexes; superior aggregates are formed and the coagula precipitate, allowing the separation of the pollutants from the aqueous phase:

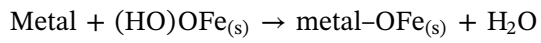

Metal $+(\mathrm{HO}) \mathrm{OAl}_{(\mathrm{s})} \rightarrow$ metal-OAl $_{(\mathrm{s})}+\mathrm{H}_{2} \mathrm{O}$

The second mechanism considers electrostatic attraction between the heavy metal pollutant and the coagulant floc. On the basis of existence of areas of apparent positive or negative charge in the floc, the negative apparent charge area attracts the heavy metal in solutions allowing their coagulation in the floc, which finally precipitates. Furthermore, the large surface areas of freshly formed amorphous coagulant flocs can also adsorb soluble ions and/or trap colloidal particles, which are separated from the aqueous solution by a third mechanism [50].

It is necessary to indicate that coagulation is not the only removal mechanism of heavy metals in EC. Electrochemical reduction of these species onto the cathode surface is also feasible, improving the removal efficiencies of these pollutants [51].

\subsubsection{Organics removal}

The different nature of organic pollutants, depending on their structures and functional groups, has an important influence on the mechanisms, involving their coagulation. The main mechanisms of organic pollutants are: complexation, charge neutralization, entrapment, adsorption and/or the combination of them [47,52].

The complexation mechanism is similar to that described on heavy metals removal, where the organic pollutant acts as a ligand. Thus, the organic pollutant is coordinated to the metallic center by their functional groups and precipitates within the coagulant floc.

On the other hand, the charge neutralization or destabilization is one of the most common mechanisms with organics. The coagulants act as charge shielding, consequently, the double layer of pollutant is compressing, thus favoring the formation of aggregates and their subsequent precipitation.

Meanwhile, entrapment mechanism consists on the trapping of organic molecules in the hydroxo-metallic coagula that drag the

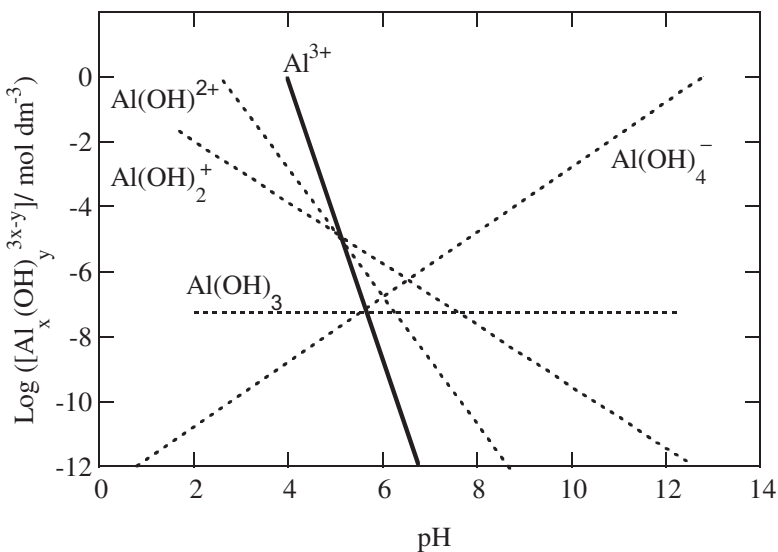

Fig. 2. Predominance-zone diagram for aluminum species in aqueous solution in function of $\mathrm{pH}$. 


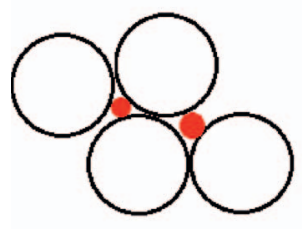

Entrapment

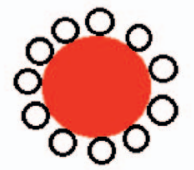

Charge neutralization or destabilization

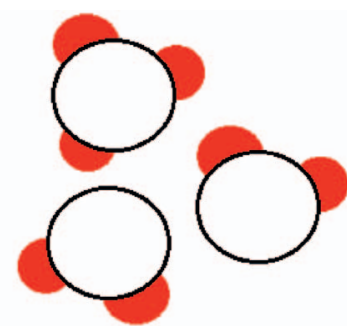

Adsorption

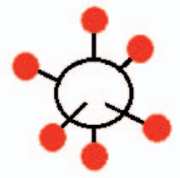

Complexation

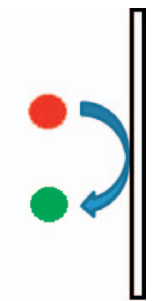

Cathodic reduction
Fig. 3. Scheme of the most important mechanisms of pollutants removal by electrocoagulation technologies. pollutants with them. Consistently, this mechanism is preferred at high dosages of coagulant in solution.

The last mechanism is called adsorption, which presents similarities to entrapment approach but with a slight difference. While in entrapment the pollutant is physically dragged by the coagula; the pollutant presents physico-chemical interactions that favor its adsorption onto the coagulant species surface during adsorption approach.

The predominance of each mechanism depends on the organic pollutant nature (charge, size, hydrophobicity, etc), the coagulant type and its dosage. However, the $\mathrm{pH}$ and other water matrix effects can also influence markedly on the EC performance [13]. It is important to highlight that the general mechanism to remove pollutants by EC is very complex because different ways could coexist simultaneously, enhancing the removal efficiency [48].

\subsection{Faraday law}

Faraday's law ( $\mathrm{m}=\mathrm{AWIt} / \mathrm{zF}$ ) is obey when EC is applied [53], where $m$ is the total mass of iron or aluminum $(\mathrm{g})$, AW is the atomic weight of the elemental coagulant precursor (i.e., $55.85 \mathrm{~g} \mathrm{~mol}^{-1}$ for $\mathrm{Fe}$ and $26.98 \mathrm{~g} \mathrm{~mol}^{-1}$ for Al), $I$ is the electric current (A), $t$ is time (s), $\mathrm{z}$ is number of electrons transferred, and $\mathrm{F}$ is the Faraday's constant (96,486C/eq) [54-57]. Then, electrodissolved coagulant concentrations increase linearly with the amount of electrical charge passed, as predicted by Faraday's law [22,58-60]. Accurate Faraday's law predictions also arise from vigorously cleaning the anode prior to each experiment $[22,61]$ and it also allows to consider the effects of chemical dissolution, pitting corrosion, and chlorine generation. Electrodissolved iron and aluminum undergo hydrolysis to form various mono, di, and polynuclear complexes, which behave as Brønsted acids, consume buffering capacity and tend to reduce $\mathrm{pH}$ [62-65]. Hydroxyl ions released at the cathode tend to neutralize the Brønsted acidity of hydrolysis products even causing a temporary upward drift in $\mathrm{pH}$ for typical initial $\mathrm{pH}$ values (depending on the buffering capacity of the feed water, current density, and electrolysis duration [22,55,61], as discussed below). Variations in $\mathrm{pH}$ conditions have been reported for high alkalinity waters or when electrolysis is performed for short times $[54,61,66]$. Electrodissolution of highly soluble Fe(II) has been confirmed by direct aqueous phase measurements [53,67-69] and it can be problematic since it does not directly induce sweep coagulation. Consequently, Fe(III) is preferred over Fe(II) as a coagulant for water purification applications (see below sections).

\section{Factors affecting electrocoagulation}

\subsection{Effect of electrode material}

Obviously, the choice of electrode material is one of EC control parameters that not only impacts the performance and efficiency of the process, but it is also associated to the cost. In the case of EC efficiency, the anodic dissolution, the percentage of pollutant removed and the coagulant required are significant parameters that play an important role. These are directly associated to the ionic metallic species that are released. In this frame, higher charge valence metal-ionic coagulants are preferred due to their greater electrical double-layer compression that enhances the pollutants coagulation. Typically, aluminum and iron electrodes are used because of the coagulating properties of multivalent ions [36]. Nevertheless, other feature is that aluminum and iron chloride salts are the most used coagulants and the most conventionally accepted in coagulation water-treatment [18]. Besides, these materials are also preferred for their easily availability, their low cost and their high electrodissolution rates.

\subsection{Effect of $p H$}

The $\mathrm{pH}$ of the solution plays an important role in electrochemical and chemical coagulation processes $[16,70]$. The first effect is related to the coagulant in solution that presents different species in equilibrium depending on the $\mathrm{pH}$ : the metal ionic species, the monomeric hydroxide-complexes and the polymeric hydroxide-complexes. The distribution of these species as a function of the $\mathrm{pH}$ are usually presented in the PZD by using the relationship between the negative value of the logarithm concentration expression as a function of the $\mathrm{pH}[35,42]$, giving valuable information about the distribution of these species in the equilibrium [18]. The type and quantity of these species are so relevant because each one of them present different interactions with pollutants, giving different coagulation performances. For example, the species in high alkaline conditions for aluminum and iron anodes are $\mathrm{Al}(\mathrm{OH})_{4}{ }^{-}$ and $\mathrm{Fe}(\mathrm{OH})_{4}{ }^{-}$, respectively. These species present poor coagulative activity [71]; then, typically (excluding some polyaluminum products), the coagulation is performed at slightly acidic conditions (Fe: 4-5 and Al: 5-6). pH conditions significatively vary the physiochemical properties of coagulants, such as: (i) the solubility of metal hydroxides, (ii) the electrical conductivity of metal hydroxydes and (iii) the size of colloidal particles of coagulant complexes [72,73]. Thus, neutral and alkaline media are preferred for coagulation. 
The second noteworthy effect is related to the changes on the chemical structure of the pollutants due to the effect of the $\mathrm{pH}$. Protonation/deprotonation of functional groups of the pollutants, depending on their pKa, directly affects the pollutants net charges as well as their electrostatic interactions. Hence, modifying the double-layer and consequently affecting the aggregates formation. Due to the different physico-chemical character of the pollutants as a function of $\mathrm{pH}$, this parameter has to be optimized according to the target pollutant nature and the effluent conditions [26,74,75].

Nevertheless, other effects can be also related to the $\mathrm{pH}$, such as, the influence of other species present in the actual water matrix. This is the case of different anions that could be affected by $\mathrm{pH}$, affecting their apparent charge and consequently their influence on the double-layer shielding of the coagulants [72,76] or their oxidative character [77]. Thus, this inert species have an effect on the optimum $\mathrm{pH}$ condition for EC processes.

\subsection{Effect of current density}

The applied current density (j) controls the electrochemical reactions that take place $[9,20]$ in solution (e.g.: electrodissolution rate, gas evolution, electroflotation, water reactions, etc. [17]) as well as their extension and kinetics. Consequently, the $j$ defines (with the applied potential) the energy consumption associated to the operation of the electrochemical process.

In general, direct current (DC) is the kind of electric current more extensively used in EC [78]. However, the anodic surface can be isolated by the formation of a stable oxide layers due to the oxidation reactions that promote the corrosion phenomena, generating passivation effects. The passivation of the sacrificial anode increases the ohmic resistance (R), and consequently, the cell potential rises, increasing the operational costs, but the passivation decreases considerably the EC efficiency [79]. The use of alternating current (AC) can be considered as an alternative because the continuous changes of polarity avoid or reduce the formation of passivation layers and enlarge the operational life of the sacrificial anodes [80].

\subsection{Effect of supporting electrolyte}

In electrochemical processes, the supporting electrolyte is required in solution that avoids migration effects and contributes to increase the solution conductivity, diminishing the ohmic drop and the energy consumption $[9,20]$. Alternatively, the electrolyte has appreciable effects on the electrodissolution kinetics of the sacrificial anodes and it can also influence the double layer shielding by the coagulants to form the flocs [81]. Several authors have studied EC process with different supporting electrolytes $[23,77,82-85]$, where the different influences are usually associated to the anion effects rather the cations [86]. In this section, we will discuss about the influence of the electrolyte cationic and anionic nature on the EC by using $\mathrm{Al}$ and $\mathrm{Fe}$ anodes. The further discussion will be done in means of the commonly used anions $\left(\mathrm{Cl}^{-}, \mathrm{SO}_{4}{ }^{2-}, \mathrm{NO}_{3}{ }^{-}\right)$and cations $\left(\mathrm{Na}^{+}, \mathrm{K}^{+}, \mathrm{NH}_{4}{ }^{+}\right.$), although in complex water matrix, they could coexist between them and with other ionic species.

Some authors have reported an appreciable affinity of sulfate species to form complexes with aluminum [87] passivating the anodic surface. Indeed, more positive potential must be applied to incentive the anodic dissolution avoiding passive action regarding the aluminum oxidation. In fact, in case of sulfate presence, a ratio of $\left[\mathrm{Cl}^{-}\right] /$ $\left[\mathrm{SO}_{4}{ }^{2-}\right]>0.1$ is suggested to ensure an efficient release of aluminum cations during EC with $\mathrm{Al}$ anodes [86]. Conversely, sulfate has not complexation affinity with iron and it does not inhibit iron anodes oxidation. Meanwhile, nitrates inhibit electrodissolution at both sacrificial anodes, being required higher applied potentials to oxidize them $[77,81]$.

On the other hand, chloride medium favors significantly the EC process independently of the anodic material used owing to significant corrosive power of chlorides that promotes the release of coagulant species $[88,89]$. Thus, voltages required for electrodissolution are appreciably lower in the presence of chlorides as supporting electrolyte than those required at sulfate or nitrate-based electrolytes [88].

Moreover, the effect of the electrolyte can be also observed from the modification of the electrode surface during the EC treatment, as reported by Hu and co-workers [88]. By using sulfate medium, localized pitting is observed, evidencing uniform corrosion rate on the entire electrode surface. Instead, when nitrate is used, crevice corrosion occurs. Conversely, in chloride medium the electrode surface presents numerous pits and holes distributed on the surface of the anode, while other parts remain smooth. This is the typical localized pitting corrosion induced by halogens [88]. These different corrosion types, during anodic dissolution, are related to the chemical reactions involved in the presence of different electrolytes as well as the $\mathrm{pH}$ conditions. Sulfate anions are considered inert electrochemical species; while nitrate and chloride are susceptible to electrochemical reactions.

Nitrate anions can be reducted by reactions (16)-(18), producing hydroxyde which basifies the solution and consequeltly difficults the anodic disolution by the formation of oxide insoluble films on the anode surface. The formation of the insoluble films produces the formation of crevices on the anode surface [88].

$$
\begin{aligned}
& 3 \mathrm{NO}_{3}^{-}+3 \mathrm{H}_{2} \mathrm{O}+6 \mathrm{e}^{-} \rightarrow 3 \mathrm{NO}_{2}^{-}+6 \mathrm{OH}^{-} \\
& 3 \mathrm{NO}_{3}^{-}+18 \mathrm{H}_{2} \mathrm{O}+24 \mathrm{e}^{-} \rightarrow 3 \mathrm{NH}_{3}+27 \mathrm{OH}^{-} \\
& 6 \mathrm{NO}_{3}^{-}+18 \mathrm{H}_{2} \mathrm{O}+30 \mathrm{e}^{-} \rightarrow 3 \mathrm{~N}_{2}+36 \mathrm{OH}^{-}
\end{aligned}
$$

Whilst, chloride is susceptible to oxidation reactions (19) that produces chlorine that disproporcionates into hipochlorous acid and chloride by reaction (20). Afterwards hipochlorous acid leads to hipochlorite by the acid-base equilibrium (21) with $\mathrm{pKa}=7.55$ depending on the treated solution $\mathrm{pH}[9,20]$. These active chlorine species are highly oxidants and favors the chemical oxidation of the anodic surface that produces the characteristic pitting corrosion.

$2 \mathrm{Cl}^{-} \rightarrow \mathrm{Cl}_{2(\mathrm{aq})}+2 \mathrm{e}^{-}$

$\mathrm{Cl}_{2(\mathrm{aq})}+\mathrm{H}_{2} \mathrm{O} \rightarrow \mathrm{HClO}+\mathrm{Cl}^{-}+\mathrm{H}^{+}$

$\mathrm{HClO} \leftrightarrow \mathrm{ClO}^{-}+\mathrm{H}^{+}$

In fact, it is feasible the formation of oxidizing species, such as active chlorine, that can oxidize organics during the EC process. It has been demonstrated in the very recent article where the case of bronopol was studied and compared to its treatment by EAOPs [90] as well as the EC. Then, this new advantage of the EC approches opens new alternatives for the applicability of this tecnology or its combination with other processes.

Regarding the cations, not enough information about their influence during EC has been reported. However, interesting assertions have been done in the last years. For example, a neutral role in EC was determined for sodium and potassium cations because no significant enhancements have been achieved when they are used [81]. Nevertheless, ammonium cation present in the solution enhances EC efficiency, especially with $\mathrm{Al}$ anodes due to its $\mathrm{pH}$ regulation effect $[81,86]$. This trend is due to the buffering effect of ammonium/ammonia couple [91]. Thus, the hydroxyl ions electrogenerated at the cathode from water reduction reaction (2) are not only consumed to generate the hydroxo-complexes with the metals but also in means of the neutralization reaction (22) releasing ammonia, which is also in equilibrium (23) with ammonium with a $\mathrm{pKa}=9.2$ :

$\mathrm{NH}_{4}{ }^{+}+\mathrm{OH}^{-} \rightarrow \mathrm{NH}_{3}+\mathrm{H}_{2} \mathrm{O}$

$\mathrm{NH}_{3}+\mathrm{H}^{+} \leftrightarrow \mathrm{NH}_{4}^{+}$

Under these controlled $\mathrm{pH}$ conditions $(\approx 9.0$ ), a significant amount of coagulants is formed [25], improving consistently the EC efficiency for removing pollutants. 


\subsection{Reactor design parameters}

Electrochemical reactor design is an indispensable stage to reach the maximum EC efficiency. In electrochemical technologies for wastewater treatment is especially relevant the minimization of the IR-drop between electrodes in order to enhance the electrochemical conversion efficiencies and the energy requirements [92]. Generally speaking, the design of EC reactors takes into account different parameters because the effluent and diverse solid species affect the hydrodynamic conditions in the reactor during the electrolytic process. In this frame, different design inputs and typical reactors described in the literature will be presented in the following subsections.

\subsubsection{Inter-electrode gap distance}

The space between the electrodes has a direct influence on the IRdrop that is minimized decreasing the distance between anode and cathode. However, lower removal efficiencies of the pollutants from water can be achieved when short distances between the electrodes are used because several phenomena can be affected (e.g.: coagulation, flocculation, precipitation, electroflotation, etc.). These effects impact the flocs formation and their precipitation [93], avoiding the formation of aggregates because the high electrostatic effect hinders the particles collision [94]. In contrast, an excessive distance between electrodes decreases significantly the formation of flocs $[95,96]$.

\subsubsection{Electrode arrangements}

The connection mode of the electrodes in the EC cell affects not only the removal efficiency but also the energy consumption and the cost $[97,98]$. The most typical arrangements $[7,94,97,99]$ are monopolar electrodes in parallel connections (MP-P), monopolar electrodes in serial connections (MP-S) and bipolar electrodes in serial connections (BP-S). These EC arrangements are schematized in Fig. 4.

In monopolar electrodes arrangement, each one of the electrode work as anode or cathode depending on its electrical polarity in the electrochemical cell. The difference between the parallel and the serial connection is illustrated in Fig. 4. As it can be observed, in the MP-P, each sacrificial anode is directly connected with other anode in the cell; using the same condition for cathodes. Meanwhile, in the MP-S configuration, each pair anode-cathode is internally connected but they are not connected with the outer electrodes (see Fig. 4).

In the case of the bipolar electrodes, each one of the electrodes, excepting the external ones, which are monopolar, present different polarity at each one of the electrode sides depending on the charge of the electrode in front it (see Fig. 4). The connection of bipolar

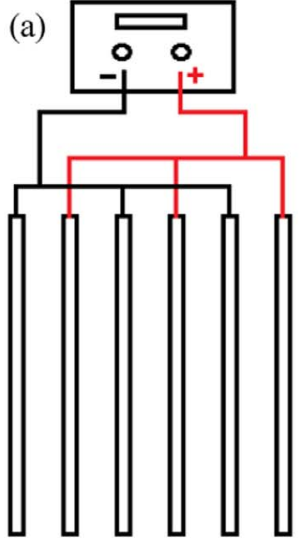

Monopolar electrodes in parallel connection (MP-P) (b)

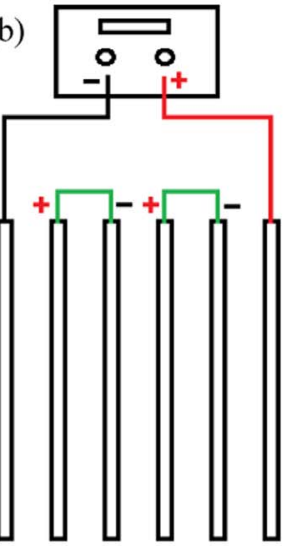

Monopolar electrodes in series connection (MP-S)
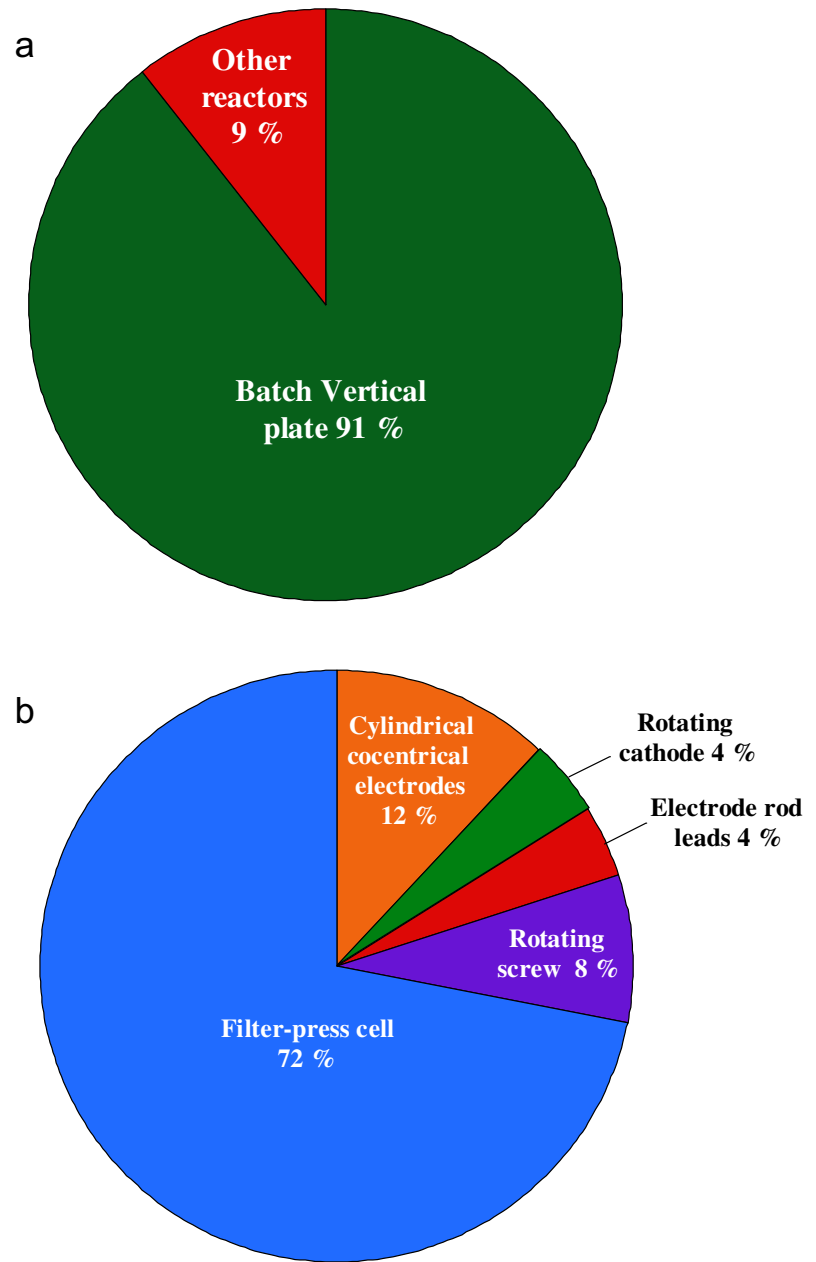

Fig. 5. Diagram of the different electrocoagulation reactors usage in the literature: (a) conventional reactors respect others and (b) the alternative reactors usage.

electrodes is always in serial mode.

It is noteworthy to mention that higher potential differences are required when a serial arrangement is used, but the same current is distributed between all electrodes (Fig. 5). Conversely, in parallel mode, the electric current is divided between the electrodes

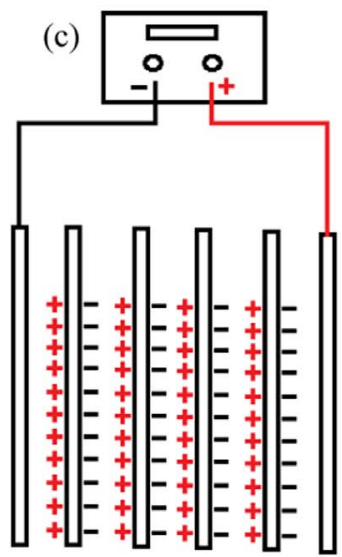

Fig. 4. Electrodes arrangements in electrocoagulation cells: (a) monopolar electrodes in parallel connection, (b) monopolar electrodes in serial connection and (c) bipolar electrodes in serial connection.

\section{Bipolar electrodes in series connection} (BP-S) 
interconnected, as function of their resistance, in the electrochemical reactor. However, notorious advantages are achieved when parallel arrangements are used in terms of the energy consumption [27,97].

Several authors have compared the performances of these different electrodes arrangements but the results are not completely conclusive because the relative efficiencies strongly depend on operating parameters discussed previously as well as the water matrix and the nature of the pollutant $[7,95,97,99-101]$. Nevertheless, restringing our conclusions to the existing literature about the electrochemical reactors, the MP-P presents generally lower operational costs, while BP-S requires lower installation maintenance during its use and sometimes it favors higher pollutant removals [95,98,102,103].

\subsection{Electrocoagulation reactors}

The type of EC reactor influences on the process performances but it also affects its operation and scale-up (see, Fig.6). The reactor most extensively used is the open batch cell with plate electrodes (Fig. 6a). The electrodes are submerged in the solution, and the effluent is conventionally stirred to be homogenized. A variation of the typical batch cell with plate electrodes reactor consist in a cylindrical reactor with concentrically inner electrodes (Fig. 6b). These electrodes (anode and cathode) present a cylinder shape and are placed one inside the other
$[104,105]$. Another feature is that the inner electrode can be replaced by a metallic rod [106]. As regards the currents applied to the inner electrode (i.e.) and the outer electrode (o.e.), it is important to consider that these electrical conditions can be different.

A variation of the cylindrical reactor was reported by Un and coworkers [107], where the anode is a cylindrical electrode but the cathode consists in a rotating impeller with two metallic blades to homogenize mechanically the solution and prevent the particles settling in the reactor during the EC (Fig. 6c). However, other electrochemical reactors have been also applied in EC processes, as showed in Fig. 6.

Other electrochemical reactor considerably used for EC is the typical filter press-cell (Fig. 6d). Higher removal efficiencies have been achieved by using this kind of EC reactor for treating solutions containing metals, non-metallic inorganic and organics pollutants respect to the conventional open batch cell with plate electrodes (Fig. 6a) [108-110].

Other novel EC systems are the continuous reactors with rotating screw type electrodes (Fig. 6e). These have been used to treat cheese whey wastewater [111] and groundwater [112]. These cells are designed with a symmetrical section to favor uniform velocity distribution of the flowing liquid around a sacrificial anode rod with a helical cathode, and both electrodes are placed in the middle of the EC reactor (with or without rotation). (a)

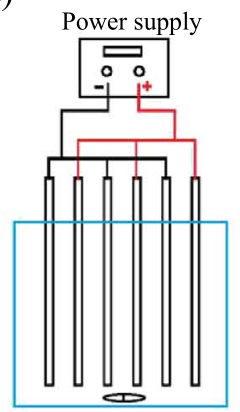

\section{Batch cell reactor with plate electrodes}

(b)

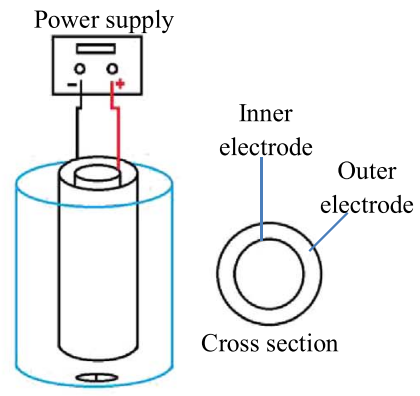

\section{Cylindrical reactor with concentrically inner electrodes}

(c)

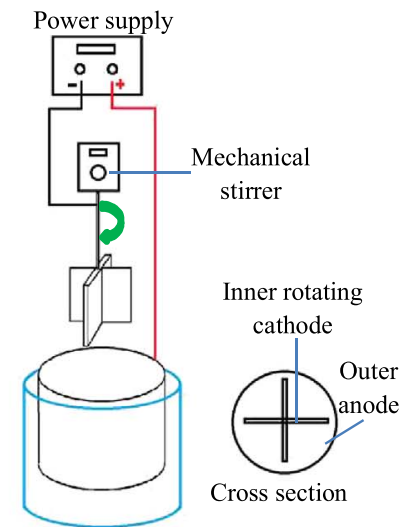

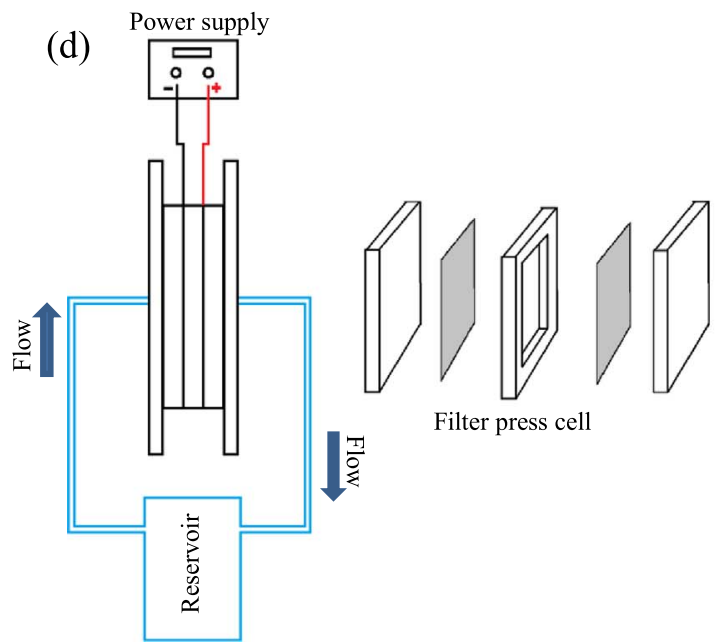

Flow electrochemical filter
press-cell reactor

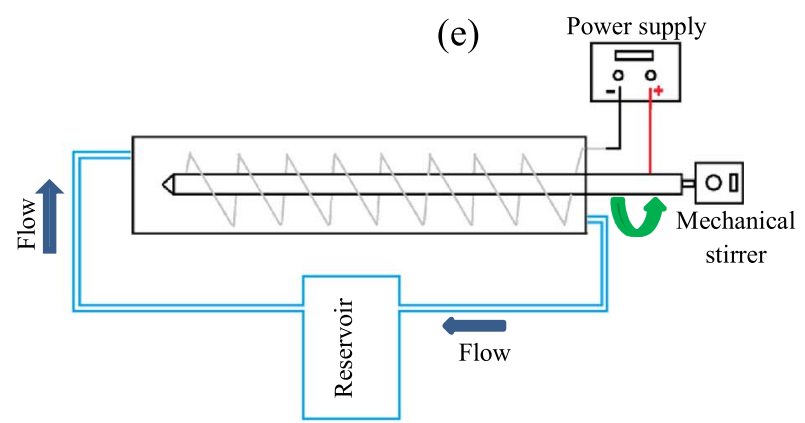
Flow electrochemical cell with rotating screw type electrodes reactor




\section{Advanced electrocoagulation processes}

The advanced EC processes are emergent technologies that use the simultaneous generation of in situ hydroxyl $(\cdot \mathrm{OH})$ radicals and other chemical oxidants by different mechanisms. These highly oxidant species improve the pollutants removal due to (i) the acceleration of the anodes dissolution by chemical oxidation and (ii) enhance the organic pollutants abatement via the oxidation action of radical species (mineralization). These novel EC technologies are presented below.

\subsection{Sono-electrocoagulation (Sono-EC)}

Sono-EC process is based on the combination of ultrasound irradiation approach with the EC process. Sound energy agitates the sample and it promotes the mixing, emulsification, homogenization and/or dispersion of particles in solution as well as the cativation effect. However, the simultaneous ultrasonication could produce undesirable side-effects [113] such:

(i) The destruction of a part of the obtained colloidal hydroxides by ultrasound-waves, which diminishes the solid phase and the removal of pollutants,

(ii) The destruction of the formed adsorption layer at the colloid particles surface that favors the redissolution of the adsorbed species,

(iii) Disorganize the migration processes reducing the pollutants coagulation, and

(iv) Difficult the flocs formation.

Consistently with the first approach, sonication can dissolve or avoid the formation of flocs during the process which reduce the efficiency appreciably. However, the generation of high-energy microenvironments in the bulk by ultrasounds depends upon the insonation power and frequency applied [114]. Thus, it is possible to control the undesirable effects and enhance positive ones for EC [113,115]:

(i) Sonication creates free radicals that improve the removal efficiency by organics oxidation, chemical polishing of the flocs surface and/or anodes dissolution by radicals oxidation,

(ii) The frequency and the intensity of the collisions between the coagulant and the pollutant particles are promoted by ultrasonic mixing, producing a significant enhancement of the removal efficiency,

(iii) Ultrasound waves reduce the thickness of the electrical diffusional layer improving the current efficiency,

(iv) Ultrasonication reduces anodic passivation effect, and

(v) The electrode surfaces can be activated due to the defects generation in the electrodes crystal lattices.

The removal efficiency of the pollutants from solution is appreciably increased in sono-EC in comparison with conventional EC process, depending on the water matrix conditions and the insonation power; for example, Raschitor et al. [115] reported an increase on the removal efficiencies from $60 \%$ in EC up to $95 \%$ by sono-EC. Thus, a significant amount of colloidal hydroxide species is produced when ultrasonication approach is used [115], and consequently, an important improvement for water purification is achieved. On the other hand, an increase on the energy consumption is achieved when both approaches are combined (electrical requirements due to the EC and the sonication process), which can be reduced when an optimization is performed. In summary, the sound generated in the treated solution does not destroy significantly the hydroxide solid phase and does not disturb the process of ion-molecular adsorption on the surface of the obtained colloidal particles, obtaining a synergic effect when both processes are coupled $[101,113]$.

\subsection{Photo-electrocoagulation (photo-EC)}

Ultraviolet (UV) irradiation is a well-known and extensively applied technology for water disinfection. The disinfection process is based on the UV radiation penetration of the cell wall affecting the genetic material (DNA and RNA) of bacterial and protozoa organisms, which obliterate their reproduction [116]. In this frame, the applicability of EC coupled with UV irradiation was proposed as an alternative. Cotillas et al. [117] presented a novel approach by using the simultaneous implementation of UV irradiation during the EC process, where a synergistic effect on the disinfection removal was observed. In this case, the implementation of UV irradiation affected slightly the turbidity reduction, but a great improvement on $E$. coli depletion rate was noticed. These effects are related to the light irradiation promotion of hydroxyl and chlorine radicals by means of hypochlorite decomposition by reactions (24)-(25) when light irradiation is applied. The results showed that it is necessary to apply 0.0085 and $0.085 \mathrm{kWh} \mathrm{m}^{-3}$ to achieve the maximum percentage of $E$. coli removal for current densities of $1.44 \mathrm{~A} \mathrm{~m}^{-2}$ and $7.20 \mathrm{~A} \mathrm{~m}^{-2}$, respectively. The differences observed in the required energy consumption can be related to the higher electric potential when current density increases and/or to the differences between the initial concentrations of microorganisms (at $1.44 \mathrm{~A} \mathrm{~m}^{-2}, E$. coli 0 : $750 \mathrm{CFU} 100 \mathrm{~mL}^{-1}$; while at $7.20 \mathrm{~A} \mathrm{~m}^{-2}$, E. coli $: 7000 \mathrm{CFU}$ $100 \mathrm{~mL}^{-1}$ ). Nevertheless, the energy consumption necessary to obtain reclaimed water is lower than $0.1 \mathrm{kWh} \mathrm{m}^{-3}$ regardless the current density applied and the initial characteristics of the wastewater. On the other hand, the energy consumption required to achieve the complete disinfection of the effluent with the UV irradiation is much higher (around $1 \mathrm{kWh} \mathrm{m}^{-3}$ ). This result means that the main energy consumption of the combined process is related to the electricity consumed by the UV lamp. This parameter can be optimized, improving the applicability of this emerging technology.

It is important to remark that, when chloride is in solution, hypochlorite is formed from chloride oxidation according to reactions (19)-(21). It should be remembered that chloride ion is quasi-ubiquitous in water effluents.

$\mathrm{ClO}^{-}+h \nu \rightarrow \mathrm{O}^{-}+\mathrm{Cl}^{\circ}$

$\mathrm{O}^{-}+\mathrm{H}_{2} \mathrm{O} \rightarrow \mathrm{OH}^{-}+{ }^{\circ} \mathrm{OH}$

Then, the generation of these oxidants enhances the electrode dissolution by means of chemical oxidation reactions and favors the bacteria depletion in water. Thus, the combination of UV radiation and EC by the so-called photo-EC approach enhances pollutants, bacterial and turbidity removal. In fact, the effect of active chlorine species was already confirmed by Brillas e co-workers when EC approach was employed [90], and the UV irradiation to promote the production of chlorine is well-known [20].

\subsection{Peroxi-coagulation and peroxi-EC}

Peroxi-coagulation or peroxi-electrocoagulation consists in the simultaneous electrogeneration of hydrogen peroxide by the bielectronic cathodic reduction of oxygen by reaction (26) and the anodic dissolution of iron as sacrificial anode [118-120]. In this case, hydrogen peroxide could be electrogenerated on carbonaceous materials such graphite (Gr), but with greater efficiency using air diffusion electrodes (ADE) with carbon-polytetreafluoroethylene or with carbon nanotubes $\left(\mathrm{ADE}_{\mathrm{CNT}}\right)$. Under these conditions the hydrated $\mathrm{Fe}(\mathrm{III})$ species are generated as coagulants that remove pollutants by their precipitation. Additionally, homogeneous $\cdot \mathrm{OH}$ radicals are generated in solution from Fenton's reaction (27) between $\mathrm{Fe}^{2+}$ species and electrogenerated hydrogen peroxide leading more $\mathrm{Fe}^{3+}$ that enhances the coagulation process [121-123]. Thus, the radicals electrogenerated favor the sacrificial anode dissolution by direct chemical oxidation reaction (28-29) and organic pollutants are mineralized to $\mathrm{CO}_{2}, \mathrm{H}_{2} \mathrm{O}$ and 
inorganic ions. Nevertheless, competitive coagulation of by-products with the hydrated Fe(III) oxide can be also attained in concomitance with the organics oxidation [124-126].

$\mathrm{O}_{2}(\mathrm{~g})+2 \mathrm{H}^{+}+2 \mathrm{e}^{-} \rightarrow \mathrm{H}_{2} \mathrm{O}_{2}$

$\mathrm{Fe}^{2+}+\mathrm{H}_{2} \mathrm{O}_{2} \rightarrow \mathrm{Fe}^{3+}+\mathrm{OH}+\mathrm{OH}^{-}$

$\mathrm{Fe}+2 \cdot \mathrm{OH} \rightarrow \mathrm{Fe}(\mathrm{OH})_{2}$

$\mathrm{Fe}+3^{\circ} \mathrm{OH} \rightarrow \mathrm{Fe}(\mathrm{OH})_{3}$

Barrera-Díaz et al. [127] reported a variation of Fe material in peroxi-coagulation by $\mathrm{Cu}$ sacrificial anode. Using this anodic material, the main coagulant species was the $\mathrm{Cu}(\mathrm{OH})_{2}$ and here the $\cdot \mathrm{OH}$ was generated by the Fenton's like reaction (30) using $\mathrm{Cu}^{+}$as catalyst instead of $\mathrm{Fe}^{2+}$. Where $\mathrm{Cu}^{+}$is generated by the reaction of $\mathrm{Cu}^{2+}$ with hydroperoxil radicals by reactions:

$\mathrm{Cu}^{+}+\mathrm{H}_{2} \mathrm{O}_{2} \rightarrow \mathrm{Cu}^{2+}+{ }^{\circ} \mathrm{OH}+\mathrm{OH}^{-}$

$\mathrm{Cu}^{2+}+\mathrm{HO}_{2} \cdot \mathrm{Cu}^{+}+\mathrm{H}^{+}+\mathrm{O}_{2}$

Although the general mechanism that describes the removal enhancement of peroxi-coagulation involves Fenton's and/or Fenton's like reactions; a peroxi-coagulation process using $\mathrm{Al}$ sacrificial anode instead $\mathrm{Fe}$ and $\mathrm{Cu}$ was initially proposed by Roa-Morales and co-workers [128], where the generation of hydroxyl radical is not related to Fenton's reaction (27) or Fenton's like reaction (30), but it is justified by the direct generation on the anode surface (M) following a similar mechanism to the proposed by Miller and Valentine [129] involving reactions with oxygen reactive species (32)-(36) and the cathodic generation by reaction (37):

$$
\begin{aligned}
& \mathrm{M}+\mathrm{H}_{2} \mathrm{O}_{2} \rightarrow \mathrm{M}^{+}+\mathrm{OH}+\mathrm{OH}^{-} \\
& \mathrm{M}^{+}+\mathrm{H}_{2} \mathrm{O}_{2} \rightarrow \mathrm{M}+\mathrm{H}^{+}+\mathrm{HO}_{2} \\
& \mathrm{M}^{+}+\mathrm{HO}_{2} \cdot \mathrm{M}+\mathrm{H}^{+}+\mathrm{O}_{2} \\
& \mathrm{M}+\mathrm{HO}_{2}^{\cdot}+\mathrm{H}^{+} \rightarrow \mathrm{M}^{+}+\mathrm{H}_{2} \mathrm{O}_{2} \\
& \mathrm{M}+{ }^{\circ} \mathrm{OH} \rightarrow \mathrm{M}^{+}+\mathrm{OH}^{-} \\
& \mathrm{H}_{2} \mathrm{O}_{2}+\mathrm{e}^{-}+\mathrm{H}^{+} \rightarrow \mathrm{H}_{2} \mathrm{O}+{ }^{\circ} \mathrm{OH}
\end{aligned}
$$

The peroxi-coagulation with $\mathrm{Al}$ anode shown also better performances which are related to the synergic effect between the $\cdot \mathrm{OH}$ and EC, like in the case of Fe anodes [127].

On the other hand, peroxi-coagulation can be implemented with simultaneous UV irradiation, commonly called as photoperoxi-coagulation or peroxi-photoelectrocoagulation [130-132]. The simultaneous irradiation with UV light promotes photochemical reactions that enhance and accelerate the Fenton's reaction, improving the pollutants mineralization by (i) the photolysis of $\mathrm{Fe}^{3+}$ complexes with some organics and degradation products such as the photodecarboxylation of carboxylic acids by general reaction (38) [133]; (ii) the additional photoreduction of $\mathrm{Fe}(\mathrm{OH})_{2}{ }^{+}$species by reaction (39) [130]; and the feasible photodecomposition of $\mathrm{H}_{2} \mathrm{O}_{2}$ by reactions (40)-(41) and/or hypochlorite generating oxidant species by reaction (24).

$$
\begin{aligned}
& \mathrm{Fe}(\mathrm{OOCR})^{2+}+h v \rightarrow \mathrm{Fe}^{2+}+\mathrm{CO}_{2}+\mathrm{R}^{\cdot} \\
& \mathrm{Fe}(\mathrm{OH})^{2+}+h v \rightarrow \mathrm{Fe}^{2+}+\mathrm{OH} \\
& \mathrm{H}_{2} \mathrm{O}_{2}+h v \rightarrow 2 \cdot \mathrm{OH} \\
& \mathrm{H}_{2} \mathrm{O}_{2}+h v \rightarrow \mathrm{H}^{\cdot}+\mathrm{HO}_{2} \cdot
\end{aligned}
$$

The implementation of these photochemical processes favors the oxidation of organic pollutants thanks to the combination of photoFenton processes, opening novel alternatives for removing different organic pollutants in water $[130,131]$.

\subsection{Electrocoagulation and membrane filtration}

Microfiltration (MF) is widely used in a large variety of filtration processes of aquatic solutions containing natural organic matter (NOM), such as: membrane bio-reactor, pretreatment for seawater and wastewater desalination plants, filtration of drinking water, tertiary treatment of wastewater for agricultural irrigation, and treatment of industrial wastes [53,134-138]. However, severe NOM-colloidal fouling is achieved when MF is used for removing NOM or to filter aquatic-NOM solutions [139]. The fouling intensity is governed by very complex relationships between the NOM properties (size, hydrophilicity, and charge), membrane characteristics (hydrophilicity, surface charge, and roughness), and the solution chemistry (e.g., pH, divalent ions such as $\mathrm{Ca}$ ) [140].

The severe NOM-colloidal fouling in MF has motivated intensive scientific efforts to develop and research fouling mitigation strategies. One potential MF fouling mitigation method that was suggested in recent years is pretreatment by EC $[66,141]$. The coagulants (iron or aluminum) produced in situ are added to the solution by dissolving the anode in an electrochemical cell. These coagulant ions ultimately lead to aggregation of the original particles in the water, which are later removed by sedimentation or filtration processes [142]. While several research groups have observed significant colloidal fouling mitigation in $\mathrm{MF}$ as a result of pretreatment with aluminum-based EC [143], the effects of iron-based EC pretreatment in solutions that contain NOM are still being debated. Bagga et al. observed only marginal fouling mitigation due to pretreatment of iron-based EC in dead-end MF of river water [54]. This marginal effect on fouling was attributed mostly to the presence of NOM, which is prone to complex with electrochemically dissolved ferric ions, and thus reduces coagulation process efficiency. On the other hand, Adin et al. obtained significant fouling mitigation due to iron-based EC pretreatment in MF of both synthetic silica solution without NOM and secondary effluent that contained organic matter $[144,145]$. Unlike the effect on fouling, the effects of EC pretreatment on contaminant removal abilities in MF were seldom investigated. Improvement resulting in 4-log or greater virus removal rates was observed in synthetic water without NOM, as a result of pretreatment of iron-based EC with MF [70,146]. However, the same authors observed low virus removal rates in hybrid $\mathrm{EC}+\mathrm{MF}$ in the presence of NOM. This observation was explained by the tendency of NOM to complex with ferric ions and thus to lower flocculation efficiency. Regarding heavy metals, Mavrov et al. [147] observed very high and improved removal ( $>98 \%$ ) of several types of heavy metals in hybrid iron-based EC and MF. Regarding aluminum-based EC, to the best of the authors' knowledge, the effect on MFcontaminant removal rates was not previously reported in the scientific literature. However, to date, there has been no comprehensive research on the effect of EC on the performances of MF for NOM removal, meaning, both the effects on fouling intensity and on removal rates [53]. Consequently, the overall potential of EC \& MF as NOM removal methods is not clear. The impreciseness regarding the performance of hybrid EC \& MF is enhanced by the ambiguous conclusions found in the literature about the efficiency of ironbased EC as a fouling mitigation method and its effect on virus removal rates in the presence of NOM. Therefore, Ben-Sasson et al. [148] studied the potential of hybrid EC \& MF as a NOM removal method. The fouling mechanisms and NOM removal rates were explored for both aluminum and iron anodes under near neutral conditions ( $\mathrm{pH} 6-8)$. The performance of the hybrid EC-MF process was compared to UF in order to evaluate its desirability for NOM removal. They concluded that, pretreatment with both iron- and aluminum-based EC can improve MF filtration of solutions containing NOM in two ways: (1) it may significantly mitigate NOM fouling and consequently, reduce the filtration energy consumption, and (2) it dramatically improves the ability of the process to remove NOM. The effect of EC on filtration performance is highly dependent on solution $\mathrm{pH}$, anode material, EC treatment time (coagulant dose), and NOM type and concentration. EC treatment times 
that are too short may lead to deterioration of fouling as compared to MF without EC. A pH value of 6 seems to be the best for achieving lower fouling and high NOM removal for both iron and aluminum electrodes. At $\mathrm{pH}$ values of 7 and above, iron-based EC led to stronger fouling mitigation and better NOM removal than aluminum-based EC. The filtration performance and NOM removal ability of the EC-MF hybrid process were superior to those of UF. This emphasizes the potential of using a hybrid EC-MF process as an alternative treatment to UF for removal of NOM [148].

In recent authoritative review by Chellam and Sari [53], they have summarized and discussed the results regarding the integration of aluminum EC and MF for drinking water treatment while including limited information on iron EC/MF. They have indicated that aluminum EC significantly reduces MF fouling by inducing the formation of a cake comprised of particles larger than in the raw water. However, aluminum flocs can compact or compress and relatively worsen MF fouling at higher pressures. New results are also included showing significant improvements in microfiltered water quality by EC pretreatment. Al $(\mathrm{OH})_{3}$ flocs sorb NOM and DBP precursors, which are then retained on the MF membrane surface. EC/MF induces a slight shift towards brominated THMs and HAAs by increasing the $\mathrm{Br}^{-} / \mathrm{DOC}$ ratio compared to the raw water. In recent reports they have showed that viruses are effectively sweep coagulated by EC and removed subsequently by MF. A thick cake layer of $\mathrm{Al}(\mathrm{OH})_{3}$ flocs further improves virus removal by acting as a dynamic membrane. In this context, they suggest that EC/ MF systems are promising alternatives for small-scale decentralized facilities because they inherently provide multiple barriers against contaminants of health concern and minimize membrane fouling while requiring limited operator attention [142].

\section{Electrocoagulation process with simultaneous coupled electroanalysis}

EC process is greatly used for removing different heavy metals as pollutants from water bodies, where many conventional analytical methods are used to quantify the remaining concentration in solution after the treatment. Atomic Absorption Spectroscopy (AAS) and Inductively Coupled Plasma-Atomic Emission Spectrometry are extensively used to this purpose achieving great results, but these methods are expensive. Electroanalytical methods are fast and cheap methods of analysis with limits of quantification at $\mathrm{ppb}$ range, because of that are considered as a potential alternative to determine the residual concentration of pollutants. Therefore, associated technologies for heavy metals determination during its elimination by electrochemical treatments like electrocoagulation are being developed.

Escobar et al. [149] reported an interesting work where a synthetic wastewater containing heavy metals was treated by EC with simulteneous metal concentration determination by means of anodic stripping voltammetry. Nanseu-Njiki et al. [150] applied EC to treat synthetic solutions containing $\mathrm{Hg}(\mathrm{II})$ and anodic redissolution in the differential pulse mode as coupled electroanalysis after the EC treatment, which allowed to optimize easily the EC parameters to obtain $99.95 \%$ of mercury removal. For instance, Eiband et al. [110] studied the EC of $\mathrm{Pb}^{2+}$ solutions with the electroanalytical Adsorptive Stripping Voltammetry technique coupled with a glassy carbon electrode. The concentrations analyzed showed an average diference of $10 \%$ in comparison with AAS, indicating that the values determined by electroanalytical approach presented high precision of quantification with good sensitivity. In addition, electroanalytical methods are cheaper and faster than the commonly used spectroscopic ones (which also require the use of more toxic and expensive reagents).

Hence, the applicability of coupled electroanalysis to follow the metal pollutants abatement during the EC treatment is feasible. The coupled electroanalyis enables the simultaneous EC process monitoring and allows to evaluate the water quality of the treated water before and the exact point where the treatment could be stopped.

\section{Electrocoagulation applications}

EC has been largely used on the wastewater treatment process to remove different pollutants that have been classified as follows: nonmetallic inorganic species, heavy metals, organic pollutants and actual industrial effluents. In the next sections, the most important results about the application of EC to remove different pollutants have been summarized and commented.

\subsection{Non-metallic inorganic species}

Non-metallic inorganic species are widespread in the earth environments and are considered inhert and inoccuous species, but up to certain concentrations. However, the human development and the extensively use of fertilizers and detergents have resulted in a growing accumulation of these species in waters.

It is the case of nitrates and phosphate, for example. The excesive release and accumulation of these species in water bodies have contributed to the eutrophication of waters, which refers to a dramatic growth of algae in continental and coastal waters afecting aquatic ecosystems. Other inorganic species that presents both beneficial and detrimental effects to human health is fluoride. Fluoride has been added to drinking waters to prevent dental cavities, nevertheless an excess in its concentration leads to varius diseases as fluorosis, arthritis and so on. In this frame, the control of these species under the limits recommended by the World Health Organization of $1.5 \mathrm{mg} / \mathrm{L}$ promoted several technologies to remove excesive contents in waters, and it is the case of EC. Thus, several authors have concentred their efforts to find methodologies to reduce the environmental impact of these pollutants [151-196]. The efficient and promising results of their abatement by EC technologies reported in the literature are presented in Table 1. Although EC can be applied to remove nitrate and sulfate; economically speking this is not feasible due to the higher consumption achived.

Analysing this Table, $>80 \%$ of concentration removal has been achieved for ammonia, boron, cyanide, flouride, nitrite, nitrate, phosphate, powdered actived carbon, silica particles, sulfide and sulfite when $\mathrm{Al}, \mathrm{Fe}$ and SS electrodes were used. In the case of ammonia, the configuration of Al-SS electrodes favors the efficient elimination of this inorganic compound from wastewaters [151], while that, Al-Al removed $80 \%$ [152]. Meanwhile, the use of Fe-Fe electrodes did not achieve significant elimination of ammonia, obtaining up to $15 \%$ [153].

Higher removal efficiencies were achieved independent of the electrode used for removing boron from synthetic effluents (see Table 1). However, higher decay in the boron concentration was attained at synthetic or real effluents by using Al-Al electrodes with MP-P reactors [83,154-162]. On the other hand, no significant differences were observed when supporting electrolyte was changed [83]. In several cases, the EC arrangement preferentially used was MP-P reactor (see Fig. 4). Regarding the $\mathrm{pH}$ conditions, the efficacy of EC approach was improved when $\mathrm{pH}$ about 7.0-8.0 was employed during boron removal [83,154-162]. Even when the nature of electrode was not noteworthy parameter for removing boron, the effective combination of $\mathrm{Fe}, \mathrm{Al}$ or SS electrodes represents a substantial reduction on the electrolysis time, depending on the boron concentrations in the effluent. Other electrode combinations such as Mg-SS [158] and Zn-SS [160] were used, obtaining removal efficiencies between $86.3 \%$ to $97.3 \%$.

Cyanide is a toxic pollutant for water ecosystems, for this reason, its elimination is important. However, the study reported by Moussavi [163] has been the unique work published until now, showing that the elimination of cyanide $(300 \mathrm{mg})$ is feasible by using $\mathrm{Al}$ or Fe electrodes. The configuration of $\mathrm{Fe}-\mathrm{Fe}$ or $\mathrm{Fe}-\mathrm{Al}$ electrodes allowed to achieve higher removal efficiencies ranging from $87 \%$ to $93 \%$ in $20 \mathrm{~min}$ of treatment.

The use of Al-Al arrangement promotes an efficient elimination of fluoride by using MP-P EC reactor [49,78,95,96,107,164-175] but the configuration BP-S was efficiently employed for removing F- from 
Table 1

Electrocoagulation treatment of non-metallic inorganic species by electrocoagulation technologies.

\begin{tabular}{|c|c|c|c|c|c|c|c|c|c|}
\hline Compound & {$\left[\mathrm{C}_{0}\right] / \mathrm{mg} / \mathrm{L}$} & $\begin{array}{l}\text { Anode- } \\
\text { cathode }\end{array}$ & Arrange. & Electrolyte & $\mathrm{pH}_{\mathrm{i}}$ & $\mathrm{j} / \mathrm{mA} \mathrm{cm}^{-2}$ & Removal/\% & Time/min & Reference \\
\hline \multirow{3}{*}{$\begin{array}{l}\text { Ammonia } \\
\qquad\left(\mathrm{NH}_{4}{ }^{+}\right)\end{array}$} & 50 & Al-SS & MP-P & n.d & 7.0 & 16.7 & 99.0 & 60 & {$[151]$} \\
\hline & 9.88 & $\mathrm{Al}-\mathrm{Al}$ & MP-P & n.d. & 7.5 & 4.8 & 80.0 & 2 & {$[152]$} \\
\hline & 20 & $\mathrm{Fe}-\mathrm{Fe}$ & MP-P & $2000 \mathrm{mg} / \mathrm{L} \mathrm{NaCl}$ & 7.0 & 33 & 15.0 & 30 & [153] \\
\hline \multirow[t]{10}{*}{ Boron (B) } & 24 & $\mathrm{Al}-\mathrm{Al}$ & MP-P & Real geothermal water & 8.0 & 6.0 & 96.0 & 30 & [83] \\
\hline & 2500 & $\mathrm{Al}-\mathrm{Al}$ & MP-P & $0.1 \mathrm{~g} / \mathrm{L} \mathrm{NaCl}$ & 8.0 & 20.0 & 90.0 & 50 & [154] \\
\hline & 500 & $\mathrm{Al}-\mathrm{Al}$ & MP-P & $15 \mathrm{mM} \mathrm{CaCl}_{2}$ & 8.0 & 3.0 & 92.5 & 120 & {$[155]$} \\
\hline & 1000 & $\mathrm{Al}-\mathrm{Al}$ & MP-P & n.d. & 8.0 & $5.0 \mathrm{~A}$ & 94.0 & - & {$[156]$} \\
\hline & 5000 & Mg-SS & MP-P & n.d. & 7.0 & 2.0 & 86.3 & 180 & {$[158]$} \\
\hline & & & & & & 5.0 & 97.3 & & \\
\hline & 5.0 & Fe-SS & MP-P & n.d. & 7.0 & 2.0 & 93.1 & 180 & [159] \\
\hline & 5.0 & Zn-SS & MP-P & n.d. & 7.0 & 2.0 & 93.2 & 180 & {$[160]$} \\
\hline & 15.0 & $\mathrm{Al}-\mathrm{Al}$ & MP-P & $\begin{array}{l}\text { Produced water from Crude Oil } \\
\text { Terminal }\end{array}$ & 7.0 & 20.0 & 98.0 & 90 & {$[161]$} \\
\hline & 15.0 & $\mathrm{Al}-\mathrm{Al}$ & MP-P & $\begin{array}{l}\text { Produced water from Crude Oil } \\
\text { Terminal }\end{array}$ & 7.0 & 12.5 & 98.0 & 90 & [162] \\
\hline \multirow[t]{4}{*}{ Cyanide $\left(\mathrm{CN}^{-}\right)$} & 300 & $\mathrm{Fe}-\mathrm{Fe}$ & MP & n.d. & 11.5 & 15.0 & 87.0 & 20 & [163] \\
\hline & & $\mathrm{Fe}-\mathrm{Al}$ & & & & & 93.0 & & \\
\hline & & $\mathrm{Al}-\mathrm{Al}$ & & & & & 35.0 & & \\
\hline & & $\mathrm{Al}-\mathrm{Fe}$ & & & & & 32.0 & & \\
\hline \multirow[t]{33}{*}{ Fluoride (F-) } & 42 & $\mathrm{Al}-\mathrm{Al}$ & MP-P & $0.025 \mathrm{M} \mathrm{Na}_{2} \mathrm{SO}_{4}$ & 3.0 & 5.0 & 87.0 & 90 & [49] \\
\hline & & $\mathrm{Fe}-\mathrm{Fe}$ & & & & & 56.7 & & \\
\hline & 20 & $\mathrm{Al}-\mathrm{Al}$ & MP-P & n.d. & 7.0 & $10 \mathrm{AC}$ & 93.0 & 60 & [78] \\
\hline & & & & & & $10 \mathrm{DC}$ & 91.5 & & \\
\hline & 25 & $\mathrm{Al}-\mathrm{Al}$ & BP-S & None & & 8.16 o.e & 100 & 9 & [88] \\
\hline & & & & $5 \mathrm{mM} \mathrm{Cl}^{-}$ & & (5.56 i.e) & 87.1 & & \\
\hline & & & & $5 \mathrm{mM} \mathrm{NO}_{3}^{-}$ & & & 85.0 & & \\
\hline & & & & $5 \mathrm{mM} \mathrm{SO}_{4}^{2-}$ & & & 32.6 & & \\
\hline & 10 & $\mathrm{Al}-\mathrm{Al}$ & MP-P & n.d. & 8.0 & 25.0 & 78.7 & 45 & [96] \\
\hline & & & BP-S & & & & 84.0 & & \\
\hline & 5.0 & $\mathrm{Al}-\mathrm{Al}$ & MP-P & $0.01 \mathrm{M} \mathrm{Na}_{2} \mathrm{SO}_{4}$ & 6.0 & 2.0 & 97.6 & 30 & [107] \\
\hline & & $\mathrm{Fe}-\mathrm{Fe}$ & & & & & 83.6 & & \\
\hline & 16 & Al-Al & MP-P & $\mathrm{NaCl}$ & 6.0 & 1.5 & 87.5 & 4 & [164] \\
\hline & 10 & $\mathrm{Al}-\mathrm{Al}$ & MP-P & n.d. & 6.0 & 5.0 & 99.0 & 50 & {$[165]$} \\
\hline & 15 & $\mathrm{Al}-\mathrm{Al}$ & MP-P & Drinking water & 5.0 & 17.1 & 98.0 & 30 & {$[166]$} \\
\hline & & & & $392 \mathrm{mg} / \mathrm{L} \mathrm{Cl}^{-}$ & & & & & \\
\hline & 19 & $\mathrm{Al}-\mathrm{Al}$ & MP-P & none & 6.5 & 0.93 & 95.2 & 10 & [167] \\
\hline & 15 & $\mathrm{Al}-\mathrm{Al}$ & MP-P & Tap water & 7.0 & 17.0 & 93.0 & 35 & [168] \\
\hline & & & & $392 \mathrm{mg} / \mathrm{L} \mathrm{Cl}^{-}$ & & & & & \\
\hline & 10 & $\mathrm{Al}-\mathrm{Al}$ & MP-P & Bore water & 7.8 & 2.0 & 100 & 60 & [169] \\
\hline & 15 & $\mathrm{Al}-\mathrm{Al}$ & MP-P & n.d. & 7.4 & 17.1 & 96.4 & 35 & {$[170]$} \\
\hline & 25 & $\mathrm{Al}-\mathrm{Al}$ & MP-P & $\mathrm{NaCl}$ & 7.0 & 11.1 & 90.0 & 25 & {$[171]$} \\
\hline & 10 & $\mathrm{Al}-\mathrm{Al}$ & MP-P & $0.1 \mathrm{M} \mathrm{NaCl}$ & $4.0-6.0$ & 1.87 & 90.0 & 60 & {$[172]$} \\
\hline & 6.0 & $\mathrm{Al}-\mathrm{Al}$ & MP-P & groundwater & 8.4 & 2.5 & 68.0 & 60 & {$[173]$} \\
\hline & 10 & $\mathrm{Al}-\mathrm{Al}$ & MP-P & $\begin{array}{l}0.5 \mathrm{~g} / \mathrm{L} \mathrm{Na}_{2} \mathrm{SO}_{4} \\
1.5 \mathrm{~g} / \mathrm{L} \mathrm{ClO}^{-}\end{array}$ & 7.7 & 5.0 & 90.0 & n.d & [174] \\
\hline & 30 & $\mathrm{Al}-\mathrm{Al}$ & MP-P & n.d. & 7.0 & 1.85 & 94.0 & 30 & {$[175]$} \\
\hline & 2.4 & $\mathrm{Al}-\mathrm{Al}$ & BP-S & River water & 7.6 & 0.3 & 83.3 & 5 & {$[176]$} \\
\hline & 27.4 & $\mathrm{Al}-\mathrm{Al}$ & BP-S & $2.0 \mathrm{~g} / \mathrm{L} \mathrm{CaCl} 2$ & 9.0 & $1 \mathrm{~A}$ & 85.4 & 5 & [177] \\
\hline & 15 & $\mathrm{Al}-\mathrm{Al}$ & BP-S & n.d. & 6.0 & n.d. & 95.0 & 20 & {$[178]$} \\
\hline & 806 & $\mathrm{Al}-\mathrm{Al}$ & BP-S & $13 \mathrm{mg} / \mathrm{L} \mathrm{Cl}^{-}$ & 7.0 & 2.0 & 98.0 & 20 & [179] \\
\hline & 25 & $\mathrm{Al}-\mathrm{Al}$ & BP-S & n.d. & 7.0 & 8.2 & 98.0 & 20 & {$[180]$} \\
\hline & 5 & $\mathrm{Al}-\mathrm{Al}$ & BP-S & Steel industrial water & 7.0 & 8.8 & 93.0 & 5 & {$[181]$} \\
\hline & 25 & $\mathrm{Fe}-\mathrm{Fe}$ & BP-S & n.d. & 6.0 & 12.5 & 60.0 & 40 & [182] \\
\hline \multirow[t]{2}{*}{ Nitrite $\left(\mathrm{NO}_{2}{ }^{-}\right)$} & 0.21 & $\mathrm{Al}-\mathrm{Al}$ & MP-P & n.d. & 7.5 & 4.8 & 80.0 & 2 & {$[152]$} \\
\hline & 10 & $\mathrm{Fe}-\mathrm{Fe}$ & MP-P & 2000 mg/L NaCl & 7.0 & 33 & 97.0 & 50 & [153] \\
\hline \multirow[t]{18}{*}{ Nitrate $\left(\mathrm{NO}_{3}{ }^{-}\right)$} & 0.18 & $\mathrm{Al}-\mathrm{Al}$ & MP-P & n.d. & 7.5 & 4.8 & 70.0 & 5 & {$[152]$} \\
\hline & 100 & $\mathrm{Fe}-\mathrm{Fe}$ & MP-P & n.d. & 7.0 & $2.9 \mathrm{~V}$ & 98.0 & 120 & [183] \\
\hline & 100 & Al-Al & MP-P & $\mathrm{NaHCO}_{3}$ & 9.0 & 2.5 & 99.0 & 60 & {$[184]$} \\
\hline & 300 & & & & & & 83.0 & 90 & \\
\hline & 300 & $\mathrm{Fe}-\mathrm{Fe}$ & MP-P & n.d. & 7.2 & $25 \mathrm{~V}$ & 84.0 & 480 & {$[185]$} \\
\hline & 150 & $\mathrm{Al}-\mathrm{Al}$ & BP-S & $\mathrm{NaCl}$ & 9.0 & $40 \mathrm{~V}$ & 89.7 & 60 & {$[186]$} \\
\hline & 55 & $\mathrm{Al}-\mathrm{Al}$ & MP-P & $60 \mathrm{mg} / \mathrm{L} \mathrm{Cl}^{-}$ & 8.2 & 15 & 81.8 & 120 & [187] \\
\hline & 203 & & & & & & 75.3 & & \\
\hline & & & & $1.0 \mathrm{~g} / \mathrm{L} \mathrm{SO}_{4}{ }^{2-}$ & & & & & \\
\hline & & & & $107 \mathrm{mg} / \mathrm{L} \mathrm{HCO}_{3}{ }^{-}$ & & & & & \\
\hline & 100 & $\mathrm{Al}-\mathrm{Fe}$ & MP-P & $100 \mathrm{mg} / \mathrm{L} \mathrm{NaCl}$ & 7.0 & 25 & 60.0 & 60 & {$[188]$} \\
\hline & & $\mathrm{Fe}-\mathrm{Fe}$ & & & & & 52.0 & & \\
\hline & & $\mathrm{Al}-\mathrm{Gr}$ & & & & & 50.0 & & \\
\hline & & $\mathrm{Al}-\mathrm{Al}$ & & & & & 45.0 & & \\
\hline & & $\mathrm{Fe}-\mathrm{Gr}$ & & & & & 35.0 & & \\
\hline & & $\mathrm{Fe}-\mathrm{Al}$ & & & & & 26.0 & & \\
\hline & & Gr-Al & & & & & 18.0 & & \\
\hline & & $\mathrm{Gr}-\mathrm{Fe}$ & & & & & 16.0 & & \\
\hline
\end{tabular}


Table 1 (continued)

\begin{tabular}{|c|c|c|c|c|c|c|c|c|c|}
\hline Compound & {$\left[\mathrm{C}_{0}\right] / \mathrm{mg} / \mathrm{L}$} & $\begin{array}{l}\text { Anode- } \\
\text { cathode }\end{array}$ & Arrange. & Electrolyte & $\mathrm{pH}_{\mathrm{i}}$ & $\mathrm{j} / \mathrm{mA} \mathrm{cm}^{-2}$ & Removal/\% & Time/min & Reference \\
\hline \multirow{18}{*}{ Phosphate $\left(\mathrm{PO}_{4}{ }^{3-}\right)$} & & $\mathrm{Gr}-\mathrm{Gr}$ & & & & & 13.8 & & \\
\hline & 30 & $\mathrm{Al}-\mathrm{Fe}$ & MP-P & $1.0 \mathrm{~g} / \mathrm{L} \mathrm{NaClreal}$ wastewater & 5.0 & 10 & 96.0 & 15 & {$[8]$} \\
\hline & & & & & & & 93.0 & 60 & \\
\hline & 83 & $\mathrm{Al}-\mathrm{Al}$ & MP-P & $500 \mathrm{mg} / \mathrm{L} \mathrm{Na}_{2} \mathrm{SO}_{4}$ & 9.0 & 3.0 & 100 & 30 & [108] \\
\hline & & $\mathrm{Fe}-\mathrm{Fe}$ & & & & & 100 & 120 & \\
\hline & 170 & $\mathrm{Al}-\mathrm{Al}$ & MP-P & River water and $\mathrm{NaCl}$ & 7.2 & $\begin{array}{l}\text { Solar Energy } \\
(14.0)\end{array}$ & 97.8 & 20 & [109] \\
\hline & 50 & Al-SS & MP-P & n.d & 7.0 & 16.7 & 99.0 & 60 & [151] \\
\hline & 0.18 & $\mathrm{Al}-\mathrm{Al}$ & MP-P & n.d. & 7.5 & 4.8 & 98.0 & 2 & {$[152]$} \\
\hline & 100 & $\mathrm{Al}-\mathrm{Al}$ & MP-P & $\mathrm{NaCl}$ & 6.2 & 10 & 94.0 & 20 & [189] \\
\hline & 200 & & & & & & 70.0 & & \\
\hline & 150 & $\mathrm{Al}-\mathrm{Al}$ & MP-P & n.d. & 3.0 & 0.5 & 100 & 40 & [190] \\
\hline & & $\mathrm{Fe}-\mathrm{Fe}$ & & & & & 42.0 & & \\
\hline & 100 & $\mathrm{Al}_{\text {alloy }}-\mathrm{SS}$ & MP-P & n.d. & 7.0 & 2.0 & 99.0 & 30 & [191] \\
\hline & & Al-SS & & & & & 87.0 & & \\
\hline & & $\mathrm{Fe}-\mathrm{SS}$ & & & & & 85.0 & & \\
\hline & 150 & $\mathrm{Fe}-\mathrm{Fe}$ & BP-S & Municipal wastewater & 9.0 & 25.0 & 97.0 & 40 & [192] \\
\hline & & & MP-P & & & & 98.8 & & \\
\hline & 306 & $\mathrm{Al}-\mathrm{Al}$ & MP-P & n.d. & 3.0 & 10 & 100 & 30 & [194] \\
\hline $\begin{array}{l}\text { Powdered Activated } \\
\text { Carbon } \\
\text { (C) }\end{array}$ & 20 & $\mathrm{Al}-\mathrm{Al}$ & MP-P & n.d. & 7.5 & 10.0 & 95.0 & 50 & [196] \\
\hline Silica particles & $\begin{array}{l}70 \text { NTU of } \\
\text { turbidity }\end{array}$ & Fe-SS & MP-P & n.d. & 9.5 & 1.4 & 95.0 & 60 & [369] \\
\hline \multirow[t]{2}{*}{ Sulfide $\left(\mathrm{S}^{2-}\right)$} & 100 & $\mathrm{Fe}-\mathrm{Fe}$ & MP-P & $30 \mathrm{mg} / \mathrm{L} \mathrm{Cl}^{-}$ & 7.0 & 32 & 99.0 & 15 & [195] \\
\hline & 500 & & & & & & 65.0 & & \\
\hline \multirow[t]{2}{*}{ Sulfite $\left(\mathrm{SO}_{3}{ }^{2-}\right)$} & 100 & $\mathrm{Fe}-\mathrm{Fe}$ & MP-P & $30 \mathrm{mg} / \mathrm{L} \mathrm{Cl}^{-}$ & 7.0 & 62 & 85.0 & 15 & [195] \\
\hline & 500 & & & & & & 46.2 & & \\
\hline \multirow{2}{*}{$\begin{array}{l}\text { Sulfate } \\
\qquad\left(\mathrm{SO}_{4}{ }^{2-}\right)\end{array}$} & 100 & $\mathrm{Fe}-\mathrm{Fe}$ & MP-P & $30 \mathrm{mg} / \mathrm{L} \mathrm{Cl}^{-}$ & 7.0 & 62 & 71.3 & 15 & [195] \\
\hline & 500 & & & & & & 30.0 & & \\
\hline
\end{tabular}

synthetic waters [88,95,176-182], but the efficient elimination is strongly dependent on the EC reactor and supporting electrolyte. Under $\mathrm{pH}$ conditions below 7.0, higher F- removals were attained. Another feature is that when Fe electrodes were used, a decay on the removal efficiencies was observed $[49,107,182]$. This trend is related with the particular mechanism of fluoride removal by EC, which occurs mainly by the formation of highly insoluble aluminum fluoride. On the other hand, when different studies have considered similar initial concentration to be eliminated, the final removal efficiency was also similar in all cases, but the electrolysis time varied as a function of the kind of the effluent (synthetic or real) as well as current density by using MP-P reactors $[49,78,95,107,164-175]$. It is important to indicate that shorter electrolysis times were also spent in some cases $[164,176,177,181]$, see Table 1 .

Few studies have been performed to study the elimination of nitrite. Lin and $\mathrm{Wu}$ [153] have studied the decay of nitrite concentration $(10 \mathrm{mg} / \mathrm{L})$ with Fe-Fe electrodes by using MP-P configuration cell in

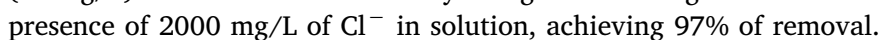
Meanwhile, when the similar EC reactor was used but with $\mathrm{Al}-\mathrm{Al}$ electrodes [152], only $80 \%$ of removal was obtained, even when the initial concentration was more that 45 -folds minor $(0.21 \mathrm{mg} / \mathrm{L})$ than that the study performed by Lin and Wu [153].

In the case of nitrate, it is efficiently eliminated from solutions by EC approach [152,183-187], avoiding the oxidation-reduction effect that difficult its complete removal. Even though, the removal efficiency is dependent on the specific operating conditions as well as on the electrochemical reactions involved. Later behavior is principally due to the formation of flocs or coagulants electrochemically formed from $\mathrm{Fe}$ or $\mathrm{Al}$ electrodes. However, when these electrodes are changed or combined with other materials, removal efficiencies decrease significantly [188].

For phosphate, sulfide, sulfite and sulfate; EC treatment is a good alternative to remove higher concentrations of these ions [8,108,109,151,152,189-194]. Lower energy requirements are necessary because of lower current densities are applied $[8,152,189,195,196]$. Special attention is given to an innovative EC alternative which employs renewal energy to supply electrical energy for depuration of river water with a reactor MP-P with Al-Al electrodes to eliminate $170 \mathrm{mg} / \mathrm{L}$ of phosphate, obtaining removal efficiencies up to $98 \%$ [109]. Meanwhile, phosphate $(150 \mathrm{mg} / \mathrm{L})$ was also removed from municipal wastewater [192], reaching efficiencies between $97 \%$ and $99 \%$ when Fe-Fe electrode arragement was employed.

\subsection{Heavy metals}

Heavy metals are known from decades to be highly toxic, mutagenic and carcinogenic pollutants [197]. The intoxication by heavy metals leads to several psychical and physical diseases for the living beings [198]. For this reason, elimination and control are a continuous preoccupation in environmental pollution issues. Heavy metal pollution increased with the development of extracting industries (metal plating, mining operation), tanneries, batteries production and others. Unfortunately, heavy metals are not biodegradable and are bio cumulative affecting the whole trofic chain. Therefore, the removal of heavy metals from aquatic environments has been a constant field of research. In this context, EC appeared as a promising and efficient technology to separate these pollutants from aqueous phase and even recover them as added value sub-product of the water treatment. Table 2 compiles several results reported in the literature classified as a function of the metallic species removed from the aquatic environment.

As an important parameter, the combination of electrodes employed as well as the EC reactor influence significantly the removal efficiency achieved in some cases, such as arsenate, arsenite, cadmium, manganes and silver $[28,44,51,63,72,73,76,82,98,104,106,185,199-218] \mathrm{Ar}-$ senite(III) was quase completely removed when $\mathrm{Al}$ and $\mathrm{Fe}$ electrodes were used for treating synthetic effluents [63,75,106,199-202]. The most used EC reactor for arsenite(III) elimination was MP-P by using soft electrolytic conditions ( $j$ or E). In the case of arsenate, higher removal efficiencies were achieved when effluents with lower concentrations were treated [76,98,104,106,185,199,203-208]. In both cases, the efficient elimination depends on the $\mathrm{pH}$, current density and 
Table 2

Electrocoagulation treatment of heavy metals by electrocoagulation technologies.

\begin{tabular}{|c|c|c|c|c|c|c|c|c|c|}
\hline Compound & {$\left[\mathrm{C}_{0}\right] / \mathrm{mg} / \mathrm{L}$} & Anode-cathode & Arrange & Electrolyte & $\mathrm{pH}_{\mathrm{i}}$ & $\mathrm{j} / \mathrm{mA} \mathrm{cm}^{-2}$ & Removal/\% & Time/min & Reference \\
\hline $\begin{array}{l}\text { Antimony } \\
{\left[\mathrm{Sb}^{3+}\right]}\end{array}$ & 28.6 & $\mathrm{Al}-\mathrm{Al}$ & BP-S & Mine water & 2.0 & 22 & 96.5 & 60 & {$[371]$} \\
\hline \multirow{12}{*}{$\begin{array}{l}\text { Arsenite (III) } \\
\qquad\left[\mathrm{AsO}_{3}{ }^{3-}\right] 7\end{array}$} & 13.4 & $\mathrm{Fe}-\mathrm{Fe}$ & MP-P & $4 \mathrm{~g} / \mathrm{L} \mathrm{NaCl}$ & 2.4 & $30(\mathrm{AC})$ & 99.6 & 60 & [63] \\
\hline & & $\mathrm{Al}-\mathrm{Al}$ & & & 4.0 & & 97.8 & & \\
\hline & & Fe-Al & & & 4.0 & & 99.6 & & \\
\hline & 0.10 & $\mathrm{Fe}-\mathrm{Fe}$ & MP-P & None & 7.0 & 0.14 & 99.9 & 60 & {$[76]$} \\
\hline & & & & $\begin{array}{l}1 \mathrm{mg} / \mathrm{L} \mathrm{PO}_{4}{ }^{3-} \\
5 \mathrm{mg} / \mathrm{L} \mathrm{SiO}_{2}\end{array}$ & & & & & \\
\hline & 0.05 & $\mathrm{Fe}-\mathrm{Fe}$ & MP-P & Synthetic water & 6.5 & 28 & 75.4 & 60 & {$[106]$} \\
\hline & 2.0 & $\mathrm{Fe}-\mathrm{Fe}$ & MP-P & n.d. & 7.0 & 0.65 & 99.0 & 60 & [199] \\
\hline & & $\mathrm{Al}-\mathrm{Al}$ & & & & 2.19 & 40.0 & & \\
\hline & & $\mathrm{Ti}-\mathrm{Ti}$ & & & & 2.19 & 60.0 & & \\
\hline & $\begin{array}{l}2.24 \\
\text { (As total) }\end{array}$ & $\mathrm{Fe}-\mathrm{Fe}$ & MP-P & $1 \mathrm{~g} / \mathrm{L} \mathrm{NaCl}$ & 2.9 & 4.6 & 99.0 & 1.5 & {$[200]$} \\
\hline & $\begin{array}{l}2.24 \\
\text { (As total) }\end{array}$ & $\mathrm{Fe}-\mathrm{Fe}$ & MP-P & $1 \mathrm{~g} / \mathrm{L} \mathrm{NaCl}$ & 2.9 & 4.6 & 99.7 & 1 & [201] \\
\hline & $6.67 \mu \mathrm{M}$ & Fe-DSA & MP-P & $20 \mathrm{mM} \mathrm{Na}_{2} \mathrm{SO}$ & 7.0 & 10 & 99.9 & 65 & [202] \\
\hline \multirow{28}{*}{$\begin{array}{l}\text { Arsenate (V) } \\
\qquad\left[\mathrm{AsO}_{4}{ }^{3-}\right]\end{array}$} & 0.10 & $\mathrm{Fe}-\mathrm{Fe}$ & MP-P & None & 7.0 & 0.14 & 99.9 & 15 & [76] \\
\hline & & & & $1 \mathrm{mg} / \mathrm{L} \mathrm{PO}_{4}{ }^{3-}$ & & & & 60 & \\
\hline & & & & $5 \mathrm{mg} / \mathrm{L} \mathrm{SiO}{ }_{2}$ & & & & 15 & \\
\hline & $20 \mathrm{mM}$ & $\mathrm{Al}-\mathrm{Al}$ & BP-S & n.d. & 7.0 & 4.0 & 99.0 & 40 & [82] \\
\hline & 0.15 & $\mathrm{Fe}-\mathrm{Fe}$ & MP-P & n.d. & 6.5 & 25 & 98.0 & 12.5 & [98] \\
\hline & & $\mathrm{Fe}-\mathrm{Fe}$ & MP-S & & 6.5 & & 98.0 & 4.5 & \\
\hline & & $\mathrm{Fe}-\mathrm{Fe}$ & BP-S & & 6.5 & & 98.0 & 2.5 & \\
\hline & & $\mathrm{Al}-\mathrm{Al}$ & MP-P & & 7.0 & & 98.0 & 8 & \\
\hline & & $\mathrm{Al}-\mathrm{Al}$ & MP-S & & 7.0 & & 98.0 & 6 & \\
\hline & & $\mathrm{Al}-\mathrm{Al}$ & BP-S & & 7.0 & & 98.0 & 4 & \\
\hline & 2200 & $\mathrm{Fe}-\mathrm{Fe}$ & MP-P & wasewater & 2.0 & 10 & 100 & 120 & [104] \\
\hline & 0.05 & $\mathrm{Fe}-\mathrm{Fe}$ & MP-P & Synthetic water & 6.5 & 0.25 & 78.0 & 60 & {$[106]$} \\
\hline & 1 & $\mathrm{Fe}-\mathrm{Fe}$ & MP-P & n.d. & 7.2 & $25 \mathrm{~V}$ & 75.0 & 480 & [185] \\
\hline & 2.0 & $\mathrm{Fe}$ & MP-P & n.d. & 7.0 & 0.65 & 99.0 & 60 & [199] \\
\hline & 100 & $\mathrm{Fe}-\mathrm{Fe}$ & MP-P & n.d. & 1.2 & $\begin{array}{l}12 \\
(\mathrm{AC})\end{array}$ & 98.0 & 180 & [203] \\
\hline & 100 & $\mathrm{Fe}-\mathrm{Fe}$ & BP-S & n.d. & 1.2 & 12(AC) & 98.0 & 120 & [204] \\
\hline & 50 & $\mathrm{Fe}-\mathrm{Fe}$ & MP-P & n.d. & 7.0 & 15 & 85.0 & 40 & {$[205]$} \\
\hline & 100 & & & & & & 64.7 & 55 & \\
\hline & 150 & & & & & & 48.5 & 55 & \\
\hline & 100 & $\mathrm{Fe}-\mathrm{SS}$ & MP-P & n.d. & 7.0 & 5.0 & 86.0 & 50 & [206] \\
\hline & & Al-SS & & & & & 73.0 & & \\
\hline & 0.13 & $\mathrm{Fe}-\mathrm{Fe}$ & BP-S & Underground water & 7.22 & 3.0 & 92.3 & 0.5 & [207] \\
\hline & 10 & $\mathrm{Fe}-\mathrm{Fe}$ & MP-P & 1000 mg/L NaCl & 7.0 & 3.0 & 99.9 & 60 & {$[208]$} \\
\hline & & $\mathrm{Al}-\mathrm{Al}$ & & & & & 99.9 & & \\
\hline & 0.0038 & $\mathrm{Fe}-\mathrm{Fe}$ & MP-P & Paper mill wastewater & 7.7 & 10 & 86.8 & 50 & [209] \\
\hline & & $\mathrm{Al}-\mathrm{Al}$ & & & & & 86.8 & 80 & \\
\hline & 0.059 & $\mathrm{Al}-\mathrm{Al}$ & MP-P & Groundwater & 8.1 & 4.0 & 66.0 & 4 & {$[210]$} \\
\hline & 0.015 & $\mathrm{Al}-\mathrm{Al}$ & BP-S & Groundwater & 5.0 & 4.3 & 91.5 & 50 & {$[211]$} \\
\hline \multirow{10}{*}{$\begin{array}{l}\text { Cadmium } \\
\qquad\left[\mathrm{Cd}^{2+}\right]\end{array}$} & 20 & $\mathrm{Zn}-\mathrm{Zn}$ & MP-P & n.d. & 7.0 & $2.0 \mathrm{AC}$ & 97.8 & 120 & [44] \\
\hline & & & & & & $2.0 \mathrm{DC}$ & 96.9 & & \\
\hline & 20 & $\mathrm{Al}_{\text {alloy}}-\mathrm{Al}_{\text {alloy }}$ & MP-P & None & 7.0 & 2.0 & 97.5 & 120 & [72] \\
\hline & & & & $65 \mathrm{mg} / \mathrm{L} \mathrm{HCO}_{3}{ }^{-}$ & & & 69.1 & & \\
\hline & & & & $250 \mathrm{mg} / \mathrm{L} \mathrm{HCO}_{3}{ }^{-}$ & & & 16.0 & & \\
\hline & & & & $50 \mathrm{mg} / \mathrm{L} \mathrm{PO}_{4}{ }^{3-}$ & & & 43.0 & & \\
\hline & & & & $15 \mathrm{mg} / \mathrm{L}$ Silicate & & & 19.0 & & \\
\hline & & & & $5 \mathrm{mg} / \mathrm{L} \mathrm{H}_{2} \mathrm{AsO}_{4}{ }^{-}$ & & & 31.0 & & \\
\hline & 9.0 & $\mathrm{Al}-\mathrm{Al}$ & MP-P & n.d. & 7.1 & 64 & 44.4 & 22 & {$[212]$} \\
\hline & 100 & $\mathrm{Al}-\mathrm{Al}$ & MP-P & n.d. & 7.0 & 3.68 & 100 & 5 & [213] \\
\hline Cesium & 5 & Mg-Zn & MP-P & n.d & 6.8 & 0.8 & 96.8 & 80 & {$[24]$} \\
\hline \multirow[t]{3}{*}[\mathrm{Cs}^{+}]{} & & $\mathrm{Al}-\mathrm{Zn}$ & & & & & 92.4 & & \\
\hline & & $\mathrm{Zn}-\mathrm{Zn}$ & & & & & 90.6 & & \\
\hline & & Fe-Zn & & & & & 90.0 & & \\
\hline \multirow{14}{*}{$\begin{array}{c}\text { Chromium (III) } \\
{\left[\mathrm{Cr}^{3+}\right]}\end{array}$} & 1700 & $\mathrm{Fe}-\mathrm{Fe}$ & MP-P & $1820 \mathrm{mg} / \mathrm{L} \mathrm{Cl}^{-}$ & 3.4 & 10.84 & 81.5 & 50 & {$[100]$} \\
\hline & & & BP-S & & & 32.52 & 99.9 & & \\
\hline & 1000 & $\mathrm{Al}-\mathrm{Al}$ & MP-P & $1000 \mathrm{mg} / \mathrm{L} \mathrm{NaCl}$ & 3.4 & 48.78 & 100 & 60 & [102] \\
\hline & 485 & $\mathrm{Fe}-\mathrm{Fe}$ & MP-P & $1000 \mathrm{mg} / \mathrm{L} \mathrm{NaCl}$ & 2.3 & 6.5 & 99.4 & 1 & [201] \\
\hline & 1000 & $\mathrm{Fe}-\mathrm{Fe}$ & MP-P & $1000 \mathrm{mg} / \mathrm{L} \mathrm{NaCl}$ & 3.4 & 48.78 & 100 & 40 & [219] \\
\hline & & & & & & 32.78 & 100 & 60 & \\
\hline & 200 & $\mathrm{Al}-\mathrm{Al}$ & MP-P & n.d. & 4.23 & $9.14 \mathrm{~V}$ & 91.0 & 10 & {$[220]$} \\
\hline & 44.5 & $\mathrm{Fe}-\mathrm{Al}$ & MP-P & n.d. & 3.0 & 10 & 100 & 20 & {$[221]$} \\
\hline & 45 & $\mathrm{Fe}-\mathrm{Fe}$ & MP-P & Electroplating effluent & 3.0 & 10 & 100 & 60 & {$[222]$} \\
\hline & & $\mathrm{Al}-\mathrm{Al}$ & & & & & 99.8 & & \\
\hline & & $\mathrm{Fe}-\mathrm{Al}$ & & & & & 100 & & \\
\hline & & $\mathrm{Al}-\mathrm{Fe}$ & & & & & 95.6 & & \\
\hline & 1490 & $\mathrm{Fe}-\mathrm{Fe}$ & MP-P & Electroplating effluent & 4.0 & 50 & 100 & 45 & [223] \\
\hline & 93.2 & $\mathrm{Fe}-\mathrm{Fe}$ & MP-P & Metal plating wastewater & 9.56 & 4 & 100 & 45 & {$[224]$} \\
\hline
\end{tabular}


Table 2 (continued)

\begin{tabular}{|c|c|c|c|c|c|c|c|c|c|}
\hline Compound & {$\left[\mathrm{C}_{0}\right] / \mathrm{mg} / \mathrm{L}$} & Anode-cathode & Arrange & Electrolyte & $\mathrm{pH}_{\mathrm{i}}$ & $\mathrm{j} / \mathrm{mA} \mathrm{cm}^{-2}$ & Removal/\% & Time/min & Reference \\
\hline & 150 & $\mathrm{Fe}-\mathrm{Fe}$ & MP-P & $1000 \mathrm{mg} / \mathrm{L} \mathrm{NaCl}$ & 8 & 10 & 100 & 20 & [237] \\
\hline Chromium (VI) & 50 & $\mathrm{Al}-\mathrm{Al}$ & MP-P & $0.025 \mathrm{M} \mathrm{Na}_{2} \mathrm{SO}_{4}$ & 3.0 & 5.0 & 25.2 & 90 & [49] \\
\hline$\left[\mathrm{CrO}_{4}^{2-}\right]$ & & $\mathrm{Fe}-\mathrm{Fe}$ & & & & & 99.8 & & \\
\hline \multirow[t]{31}{*}[\mathrm{Cr}_{2}\mathrm{O}_{7}{}^{2-}]{} & 50 & $\mathrm{Al}-\mathrm{Al}$ & BP-S & $1700 \mathrm{mg} / \mathrm{L} \mathrm{NaNO}_{3}$ & 5.5 & 3.3 & 70.0 & 150 & [51] \\
\hline & 20 & & & & & & 75.0 & 120 & \\
\hline & 10 & & & & & & 70.0 & 60 & \\
\hline & 300 & $\mathrm{Al}-\mathrm{Al}$ & MP-P & n.d & 4.0 & 40 & 100 & 80 & [75] \\
\hline & 150 & & & & & & 100 & 60 & \\
\hline & 75 & & & & & & 100 & 40 & \\
\hline & 300 & $\mathrm{Fe}-\mathrm{Fe}$ & MP-P & $1500 \mathrm{mg} / \mathrm{L} \mathrm{NaCl}$ & 4.5 & 1 & 98.2 & 20 & [105] \\
\hline & & & MP-S & & & & 98.8 & & \\
\hline & 1.0 & $\mathrm{Fe}-\mathrm{Fe}$ & MP-P & $181 \mathrm{mg} / \mathrm{L} \mathrm{Cl}^{-}$ & 8.0 & 7.9 & 100 & 3 & [112] \\
\hline & & $\mathrm{Fe}-\mathrm{Al}$ & & $376 \mathrm{mg} / \mathrm{L} \mathrm{SO}_{4}{ }^{2-}$ & & & 100 & 3 & \\
\hline & & $\mathrm{Al}-\mathrm{Al}$ & & & & & 100 & 10 & \\
\hline & 887 & $\mathrm{Fe}-\mathrm{Fe}$ & MP-P & Electroplating effluent & 4.0 & 50 & 100 & 15 & {$[223]$} \\
\hline & 50 & $\mathrm{Al}-\mathrm{Al}$ & MP-P & n.d & 3.4 & 4.36 & 42.0 & 40 & {$[226]$} \\
\hline & 20 & $\mathrm{Fe}-\mathrm{Fe}$ & BP-S & $1700 \mathrm{mg} / \mathrm{L} \mathrm{NaNO}_{3}$ & 5.0 & 1.3 & 100 & 60 & [227] \\
\hline & & & & & & 38.9 & 13.4 & 60 & \\
\hline & 50 & $\mathrm{Al}-\mathrm{Fe}$ & MP-P & $1.0 \mathrm{~g} / \mathrm{L} \mathrm{NaCl}$ & 5.0 & 5.0 & 15.0 & 30 & {$[228]$} \\
\hline & & $\mathrm{Fe}-\mathrm{Fe}$ & & $1.0 \mathrm{~g} / \mathrm{L} \mathrm{NaCl}$ & & & 99.0 & & \\
\hline & & $\mathrm{Fe}-\mathrm{Fe}$ & & $1.0 \mathrm{~g} / \mathrm{L} \mathrm{NaNO}_{3}$ & & & 18.0 & & \\
\hline & & $\mathrm{Fe}-\mathrm{Fe}$ & & $1.0 \mathrm{~g} / \mathrm{L} \mathrm{Na}_{2} \mathrm{SO}_{4}$ & & & 14.0 & & \\
\hline & 100 & $\mathrm{Al}-\mathrm{Al}$ & MP-P & n.d & 5.0 & $24 \mathrm{~V}$ & 90.4 & 24 & [229] \\
\hline & 200 & $\mathrm{Al}-\mathrm{Al}$ & MP-P & wastewater & 7.5 & 15.0 & 67.3 & 60 & {$[230]$} \\
\hline & & $\mathrm{Fe}-\mathrm{Fe}$ & & & & & 100 & & \\
\hline & 1470 & SS-SS & MP-P & $33.6 \mathrm{mM} \mathrm{NaCl}$ & 1.84 & 31.7 & 100 & 70 & {$[231]$} \\
\hline & 100 & $\mathrm{Fe}-\mathrm{Al}$ & MP-P & $30 \mathrm{mg} / \mathrm{L} \mathrm{NaCl}$ & 5.0 & 15.3 & 99.0 & 25 & {$[232]$} \\
\hline & 1000 & & & $30 \mathrm{mg} / \mathrm{L} \mathrm{KCl}$ & & & 99.0 & & \\
\hline & & & & $30 \mathrm{mg} / \mathrm{L} \mathrm{NaNO}{ }_{3}$ & & & 72.0 & & \\
\hline & & & & $30 \mathrm{mg} / \mathrm{L} \mathrm{Al}{ }_{2}(\mathrm{OH})_{\mathrm{n}} \mathrm{Cl}_{6-\mathrm{n}}$ & & & 80.0 & & \\
\hline & 5 & $\mathrm{Al}_{\text {alloy }}-\mathrm{Zn}$ & MP-P & n.d. & 7.0 & 2.0 & 98.2 & 10 & [233] \\
\hline & 92 & $\mathrm{Fe}-\mathrm{Fe}$ & MP-P & $\mathrm{NaCl}$ & 2.0 & 10 & 100 & 100 & {$[235]$} \\
\hline & 52 & & & & & & 100 & 60 & \\
\hline & 10 & & & & & & 100 & 20 & \\
\hline \multirow{3}{*}{$\begin{array}{l}\text { Cobalt } \\
\qquad\left[\mathrm{Co}^{2+}\right]\end{array}$} & 400 & $\mathrm{Al}-\mathrm{Al}$ & MP-P & $\mathrm{NaCl}$ & 7.0 & 6.25 & 95.5 & 60 & [216] \\
\hline & 100 & & & & & & 100 & 35 & \\
\hline & 25 & & & & & & 100 & 15 & \\
\hline Copper & 250 & $\mathrm{Fe}-\mathrm{Fe}$ & MP-P & n.d. & 5.5 & 25 & 98.0 & 40 & {$[28]$} \\
\hline \multirow{24}{*}[\mathrm{Cu}^{2+}]{} & 250 & $\mathrm{Al}-\mathrm{Al}$ & BP-S & $1700 \mathrm{mg} / \mathrm{L} \mathrm{NaNO}_{3}$ & 5.5 & 3.3 & 100 & 15 & [51] \\
\hline & 100 & & & & & & 100 & 7 & \\
\hline & 50 & & & & & & 100 & 5 & \\
\hline & 300 & $\mathrm{Al}-\mathrm{Al}$ & MP-P & n.d & 4.0 & 40 & 100 & 50 & [75] \\
\hline & 150 & & & & & & 100 & 40 & \\
\hline & 75 & & & & & & 100 & 20 & \\
\hline & 50 & $\mathrm{Al}-\mathrm{Al}$ & MP-P & Copper production wastewater & 5.1 & 3.0 & 99.8 & 15 & [214] \\
\hline & 200 & $\mathrm{Al}-\mathrm{Al}$ & MP-P & $302 \mathrm{mg} / \mathrm{L} \mathrm{SO}_{4}{ }^{2-}$ & 3.0 & 15 & 100 & 15 & {$[217]$} \\
\hline & & & & $224 \mathrm{mg} / \mathrm{L} \mathrm{Cl}^{-}$ & & & 98.0 & 35 & \\
\hline & 5.0 & $\mathrm{Fe}-\mathrm{Al}$ & MP-P & Industrial wastewater & 6.0 & 14 & 100 & 90 & [218] \\
\hline & 45 & $\mathrm{Fe}-\mathrm{Al}$ & MP-P & n.d. & 3.0 & 10 & 100 & 20 & {$[221]$} \\
\hline & 45 & $\mathrm{Fe}-\mathrm{Fe}$ & MP-P & Electroplating effluent & 3.0 & 10 & 100 & 60 & {$[222]$} \\
\hline & & $\mathrm{Al}-\mathrm{Al}$ & & & & & 100 & & \\
\hline & & $\mathrm{Fe}-\mathrm{Al}$ & & & & & 100 & & \\
\hline & & $\mathrm{Al}-\mathrm{Fe}$ & & & & & 95.6 & & \\
\hline & 33.3 & $\mathrm{Fe}-\mathrm{Fe}$ & MP-P & Metal plating wastewater & 9.56 & 4 & 99.0 & 45 & {$[224]$} \\
\hline & 50 & $\mathrm{Al}-\mathrm{Al}$ & MP-P & $\mathrm{KCl}$ & 6.0 & 48.0 & 100 & 5 & {$[225]$} \\
\hline & 83 & $\mathrm{Al}-\mathrm{Fe}$ & MP-P & Mechanical polishing wastewater & 6.0 & $30 \mathrm{~V}$ & 99.0 & 30 & {$[236]$} \\
\hline & & $\mathrm{Al}-\mathrm{Al}$ & & & & & 99.0 & & \\
\hline & & $\mathrm{Fe}-\mathrm{Fe}$ & & & & & 99.0 & & \\
\hline & & $\mathrm{Fe}-\mathrm{Al}$ & & & & & 99.0 & & \\
\hline & 12.0 & $\mathrm{Fe}-\mathrm{Fe}$ & MP-P & $\begin{array}{l}173 \mathrm{mg} / \mathrm{L} \mathrm{HCO}_{3}{ }^{-}, 43 \mathrm{mg} / \mathrm{L} \mathrm{SO}_{4}{ }^{2-}, 3.3 \mathrm{mg} / \mathrm{L} \mathrm{NO}_{3}{ }^{-}, \\
7.3 \mathrm{mg} / \mathrm{L} \mathrm{Cl}^{-}\end{array}$ & 7.75 & 1.4 & 100 & 150 & [239] \\
\hline & 20.0 & $\mathrm{Zn}-\mathrm{Zn}$ & MP-P & n.d. & 7.0 & 0.5 & 96.6 & 35 & {$[240]$} \\
\hline & 15.4 & $\mathrm{Fe}-\mathrm{Al}$ & MP-P & n.d. & 5.0 & 8.0 & 95.0 & 60 & [241] \\
\hline \multirow{4}{*}{$\begin{array}{l}\text { Indium } \\
\qquad\left[\mathrm{In}^{3+}\right]\end{array}$} & 20 & $\mathrm{Fe}-\mathrm{Al}$ & MP-P & $100 \mathrm{mg} / \mathrm{L} \mathrm{NaCl}$ & 2.5 & $20 \mathrm{~V}$ & 78.3 & 90 & [101] \\
\hline & & $\mathrm{Al}-\mathrm{Fe}$ & & & & & 70.1 & & \\
\hline & & $\mathrm{Fe}-\mathrm{Fe}$ & & & & & 31.4 & & \\
\hline & & $\mathrm{Al}-\mathrm{Al}$ & & & & & 15.8 & & \\
\hline \multirow{3}{*}{$\begin{array}{l}\text { Iron } \\
\qquad\left[\mathrm{Fe}^{2+}\right]\end{array}$} & 25 & $\mathrm{Al}-\mathrm{Al}$ & MP-P & Tap water & 7.5 & 0.4 & 99.2 & 35 & [95] \\
\hline & 220 & $\mathrm{Al}-\mathrm{Al}$ & MP-P & n.d. & 7.1 & 64 & 88.6 & 20 & [212] \\
\hline & 25 & $\mathrm{Al}_{\text {alloy }}-\mathrm{SS}$ & MP-P & Tap water & 6.5 & 0.6 & 98.8 & 60 & [243] \\
\hline \multirow{5}{*}{$\begin{array}{l}\text { Lead } \\
\qquad\left[\mathrm{Pb}^{2+}\right]\end{array}$} & 300 & $\mathrm{Al}-\mathrm{Al}$ & MP-P & $0.5 \mathrm{~mol} / \mathrm{L} \mathrm{NaNO}_{3}$ & 7.0 & 11.8 & 100 & 45 & [110] \\
\hline & & & & & & 7.9 & 100 & 75 & \\
\hline & & & & & & 3.9 & 100 & 90 & \\
\hline & 1420 & $\mathrm{Al}-\mathrm{Al}$ & MP-P & n.d. & 7.1 & 64 & 95 & 22 & [212] \\
\hline & 9.0 & $\mathrm{Fe}-\mathrm{Fe}$ & MP-S & Battery industry wastewater & 2.8 & 6.0 & 97.4 & 40 & [242] \\
\hline
\end{tabular}


Table 2 (continued)

\begin{tabular}{|c|c|c|c|c|c|c|c|c|c|}
\hline Compound & {$\left[\mathrm{C}_{0}\right] / \mathrm{mg} / \mathrm{L}$} & Anode-cathode & Arrange & Electrolyte & $\mathrm{pH}_{\mathrm{i}}$ & $\mathrm{j} / \mathrm{mA} \mathrm{cm}^{-2}$ & Removal/\% & Time/min & Reference \\
\hline & & SS-SS & & & & 8.0 & 91.4 & & \\
\hline \multirow{14}{*}{ Manganese $\left[\mathrm{Mn}^{2+}\right]$} & 250 & $\mathrm{Fe}-\mathrm{Fe}$ & MP-P & n.d. & 5.5 & 25 & 76.0 & 40 & {$[28]$} \\
\hline & 2.0 & Mg-Zn & MP-P & None & 7.0 & 0.5 & 97.2 & 100 & [73] \\
\hline & & & & $5 \mathrm{mg} / \mathrm{L} \mathrm{CO}_{3}^{2-}$ & & & 72.8 & & \\
\hline & & & & $5 \mathrm{mg} / \mathrm{L} \mathrm{PO}_{4}{ }^{3-}$ & & & 64.7 & & \\
\hline & & & & $5 \mathrm{mg} / \mathrm{L} \mathrm{H}_{2} \mathrm{AsO}_{4}^{-}$ & & & 54.6 & & \\
\hline & & & & $5 \mathrm{mg} / \mathrm{L}$ Silicate & & & 82.4 & & \\
\hline & 6.0 & $\mathrm{Al}-\mathrm{Al}$ & MP-P & Copper production wastewater & 5.1 & 3.0 & 84.0 & 15 & [214] \\
\hline & 100 & Al-Al & MP-P & $\mathrm{NaCl}$ & 7.0 & 6.25 & 94.0 & 60 & [215] \\
\hline & 400 & $\mathrm{Al}-\mathrm{Al}$ & MP-P & $\mathrm{NaCl}$ & 7.0 & 6.25 & 86.6 & 120 & [216] \\
\hline & 100 & & & & & & 100 & 100 & \\
\hline & 25 & & & & & & 100 & 40 & \\
\hline & 200 & Al-Al & MP-P & $350 \mathrm{mg} / \mathrm{L} \mathrm{SO}_{4}{ }^{2-}$ & 3.0 & 15 & 67.6 & 35 & [217] \\
\hline & & & & $217 \mathrm{mg} / \mathrm{L} \mathrm{Cl}^{-}$ & & & 45.6 & 35 & \\
\hline & 5.0 & $\mathrm{Fe}-\mathrm{Al}$ & MP-P & Industrial wastewater & 6.0 & 14 & 89.0 & 90 & {$[218]$} \\
\hline \multirow[t]{2}{*}{ Mercury (II) $\left[\mathrm{Hg}^{2+}\right]$} & 0.4 & $\mathrm{Fe}-\mathrm{Fe}$ & MP-P & $\mathrm{NaCl}$ & 7.0 & 25 & 99.9 & 15 & {$[150]$} \\
\hline & & $\mathrm{Al}-\mathrm{Al}$ & & & & & & 25 & \\
\hline \multirow{15}{*}{$\begin{array}{l}\text { Nickel } \\
\quad\left[\mathrm{Ni}^{2+}\right]\end{array}$} & 250 & $\mathrm{Fe}-\mathrm{Fe}$ & MP-P & n.d. & 5.5 & 25 & 97.6 & 40 & {$[28]$} \\
\hline & 250 & $\mathrm{Al}-\mathrm{Al}$ & BP-S & $1700 \mathrm{mg} / \mathrm{L} \mathrm{NaNO}{ }_{3}$ & 5.5 & 3.3 & 100 & 20 & [51] \\
\hline & 100 & & & & & & 100 & 10 & \\
\hline & 50 & & & & & & 100 & 5 & \\
\hline & 300 & Al-Al & MP-P & n.d & 4.0 & 40 & 100 & 50 & [75] \\
\hline & 150 & & & & & & 100 & 40 & \\
\hline & 75 & & & & & & 100 & 20 & \\
\hline & 394 & $\mathrm{Fe}-\mathrm{Al}$ & MP-P & n.d. & 3.0 & 10 & 100 & 20 & {$[221]$} \\
\hline & 394 & $\mathrm{Fe}-\mathrm{Fe}$ & MP-P & Electroplating effluent & 3.0 & 10 & 98.0 & 60 & {$[222]$} \\
\hline & & $\mathrm{Al}-\mathrm{Al}$ & & & & & 96.5 & & \\
\hline & & $\mathrm{Fe}-\mathrm{Al}$ & & & & & 99.9 & & \\
\hline & & $\mathrm{Al}-\mathrm{Fe}$ & & & & & 76.3 & & \\
\hline & 57.6 & $\mathrm{Fe}-\mathrm{Fe}$ & MP-P & Metal plating wastewater & 9.56 & 4 & 98.0 & 45 & [224] \\
\hline & 20 & $\mathrm{Fe}-\mathrm{Fe}$ & MP-P & $\begin{array}{l}173 \mathrm{mg} / \mathrm{L} \mathrm{HCO}_{3}{ }^{-}, 43 \mathrm{mg} / \mathrm{L} \mathrm{SO}_{4}{ }^{2-}, 3.3 \mathrm{mg} / \mathrm{L} \mathrm{NO}_{3}{ }^{-}, \\
7.3 \mathrm{mg} / \mathrm{L} \mathrm{Cl}^{-}\end{array}$ & 7.75 & 1.4 & 98.0 & 100 & [239] \\
\hline & 1.7 & $\mathrm{Fe}-\mathrm{Al}$ & MP-P & n.d. & 5.0 & 8.0 & 95.0 & 60 & [241] \\
\hline \multirow{3}{*}{$\begin{array}{l}\text { Silver } \\
\qquad\left[\mathrm{Ag}^{+}\right]\end{array}$} & 50 & $\mathrm{Al}-\mathrm{Al}$ & BP-S & $1700 \mathrm{mg} / \mathrm{L} \mathrm{NaNO}_{3}$ & 5.5 & 3.3 & 66.0 & 50 & [51] \\
\hline & 20 & & & & & & 60.0 & 30 & \\
\hline & 10 & & & & & & 90.0 & 30 & \\
\hline \multirow{6}{*}{$\begin{array}{l}\text { Strontium } \\
{\left[\mathrm{Sr}^{2+}\right]}\end{array}$} & 5 & Mg-Zn & MP-P & n.d & 6.8 & 0.8 & 97.0 & 80 & [24] \\
\hline & & $\mathrm{Fe}-\mathrm{Zn} \mathrm{Al}-\mathrm{Zn}$ & & & & & 95.2 & & \\
\hline & & $\mathrm{Zn}-\mathrm{Zn}$ & & & & & 91.4 & & \\
\hline & & & & & & & 89.6 & & \\
\hline & 10 & SS-SS & MP-P & $1 \mathrm{M} \mathrm{NaCl}$ & 5.0 & 8.0 & 93.0 & 50 & {$[272]$} \\
\hline & & $\mathrm{Al}-\mathrm{Al}$ & & & & & 77.0 & & \\
\hline Zinc & 250 & $\mathrm{Fe}-\mathrm{Fe}$ & MP-P & n.d. & 5.5 & 25 & 98.0 & 40 & {$[28]$} \\
\hline \multirow{17}{*}[\mathrm{Zn}^{2+}]{} & 250 & $\mathrm{Al}-\mathrm{Al}$ & BP-S & $1700 \mathrm{mg} / \mathrm{L} \mathrm{NaNO}_{3}$ & 5.5 & 3.3 & 100 & 20 & [51] \\
\hline & 100 & & & & & & 100 & 10 & \\
\hline & 50 & & & & & & 100 & 5 & \\
\hline & 300 & Al-Al & MP-P & n.d & 4.0 & 40 & 100 & 50 & [75] \\
\hline & 150 & & & & & & 100 & 40 & \\
\hline & 75 & & & & & & 100 & 20 & \\
\hline & 260 & Al-Al & MP-P & n.d. & 7.1 & 64 & 65.4 & 30 & {$[212]$} \\
\hline & 200 & $\mathrm{Al}-\mathrm{Al}$ & MP-P & $293 \mathrm{mg} / \mathrm{L} \mathrm{SO}_{4}{ }^{2-}$ & 3.0 & 15 & 98.0 & 35 & [217] \\
\hline & & & & $217 \mathrm{mg} / \mathrm{L} \mathrm{Cl}^{-}$ & & & 70.5 & 35 & \\
\hline & 10.0 & $\mathrm{Fe}-\mathrm{Al}$ & MP-P & Industrial wastewater & 6.0 & 14 & 100 & 90 & [218] \\
\hline & 20.4 & $\mathrm{Fe}-\mathrm{Fe}$ & MP-P & Metal plating wastewater & 9.56 & 4 & 99.0 & 45 & [224] \\
\hline & 50 & $\mathrm{Al}-\mathrm{Al}$ & MP-P & $\mathrm{KCl}$ & 6.0 & 48 & 100 & 5 & {$[225]$} \\
\hline & 400 & & & & & & 100 & 30 & \\
\hline & 20.0 & $\mathrm{Fe}-\mathrm{Fe}$ & MP-P & $\begin{array}{l}173 \mathrm{mg} / \mathrm{L} \mathrm{HCO}_{3}{ }^{-}, 43 \mathrm{mg} / \mathrm{L} \mathrm{SO}_{4}{ }^{2-}, 3.3 \mathrm{mg} / \mathrm{L} \mathrm{NO}_{3}{ }^{-}, \\
7.3 \mathrm{mg} / \mathrm{L} \mathrm{Cl}^{-}\end{array}$ & 7.75 & 1.4 & 100 & 150 & [239] \\
\hline & 11.3 & $\mathrm{Fe}-\mathrm{Al}$ & MP-P & n.d. & 5.0 & 8.0 & 95.0 & 60 & {$[241]$} \\
\hline & 3.2 & $\mathrm{Fe}-\mathrm{Fe}$ & MP-S & Battery industry wastewater & 2.8 & 6.0 & 96.5 & 40 & {$[242]$} \\
\hline & & SS-SS & & & & & 92.6 & & \\
\hline
\end{tabular}

kind of the effluent due to the parallel reactions that are involved during the formation of complex or flocs with coagulant material.

Meanwhile, an important feature was determined when cadmium was treated by EC process $[44,72,212]$. The use of different supporting electrolytes influences on the cadmium removal. For example, Vasudevan and co-workers [72] examined the elimination of cadmium in absence or in presence of specific anions, such as $\mathrm{HCO}_{3}{ }^{-}, \mathrm{PO}_{4}{ }^{3-}$, silicate and $\mathrm{AsO}_{4}{ }^{-}$. The figures demonstrated that different removal efficiencies were achieved ranging from $16 \%$ to $97 \%$ in $120 \mathrm{~min}$ of treatment depending on the anion. However, it is important to indicate that $\mathrm{Al}$ alloy electrodes were used which can be other factor that affects the efficacy of the EC approach. In fact, when $\mathrm{Al}$ electrodes were used by Pociecha and Lestan [212] to eliminate cadmium, 44.4\% was achieved. Meanwhile, higher removal efficiencies were obtained ( $>97 \%$ ) when $\mathrm{Zn}$ electrodes were employed by Vasudevan and coworkers [44].

Chromium species cause severe environmental problems in aquatic ecosystems, for this reason, their removal by EC process has been widely studied $[49,51,75,100,102,105,112,201,219-253]$. In this case, the use of $\mathrm{Al}$ and Fe electrodes is suggested because the elimination of chromium 


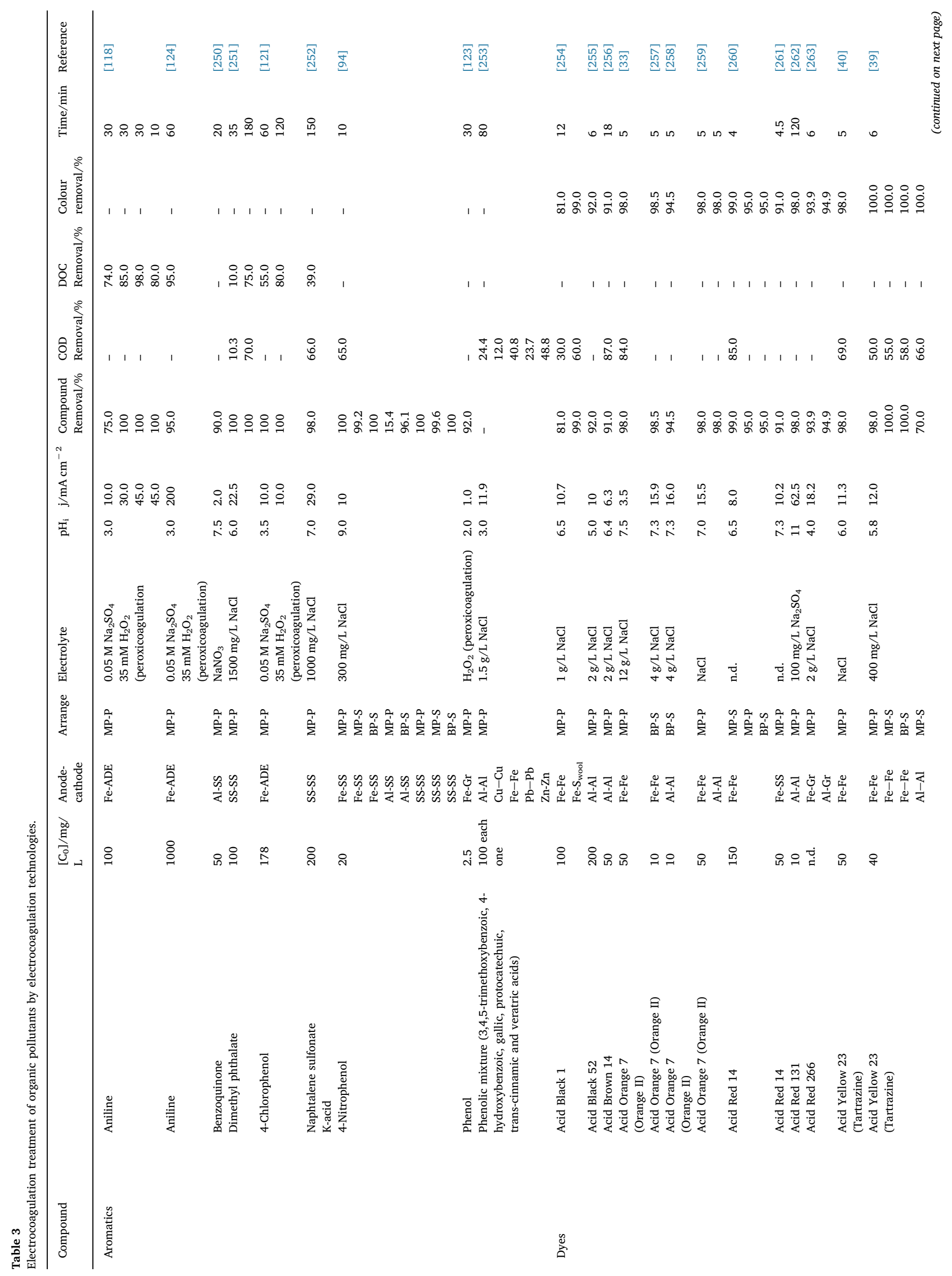




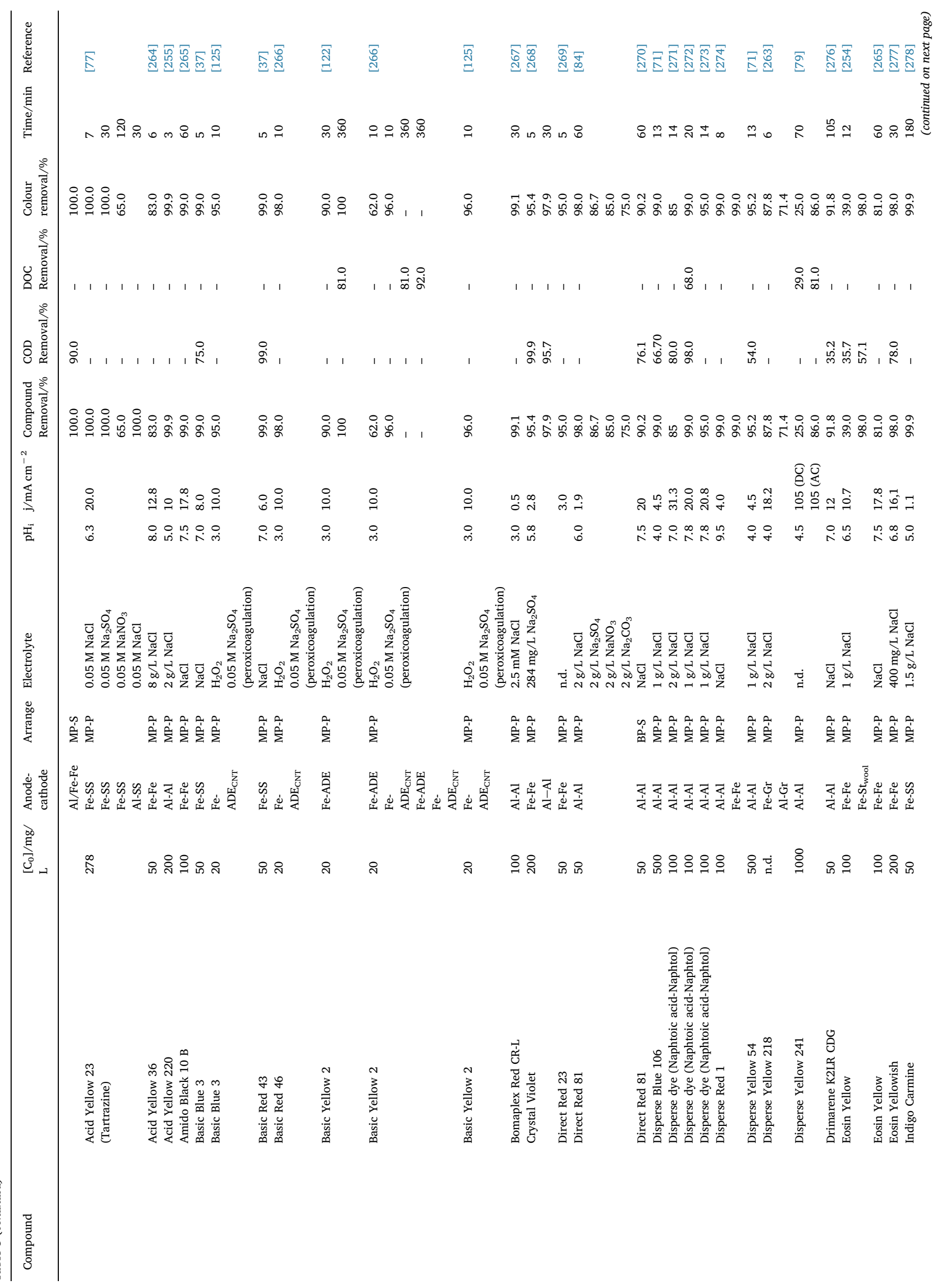




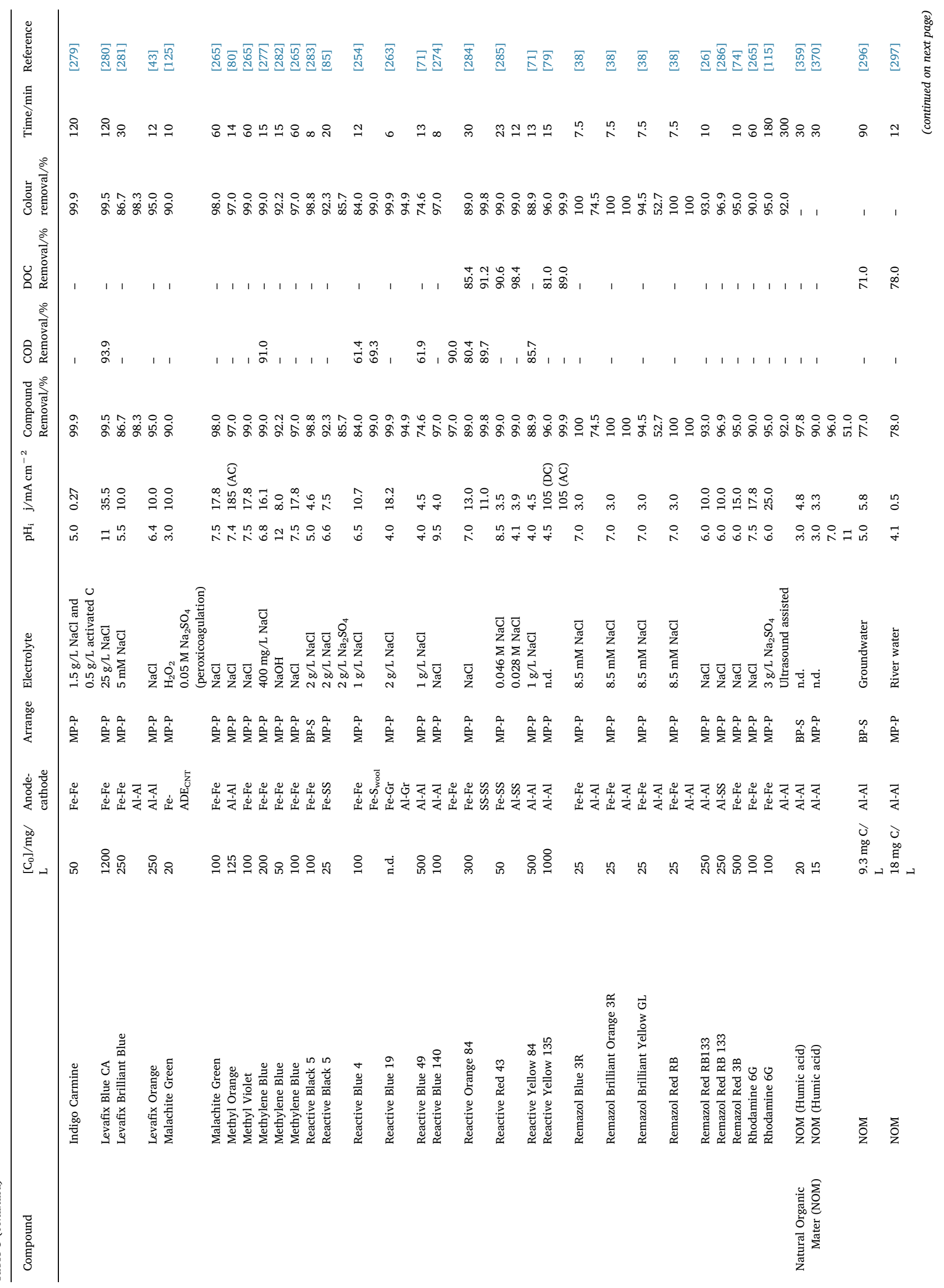




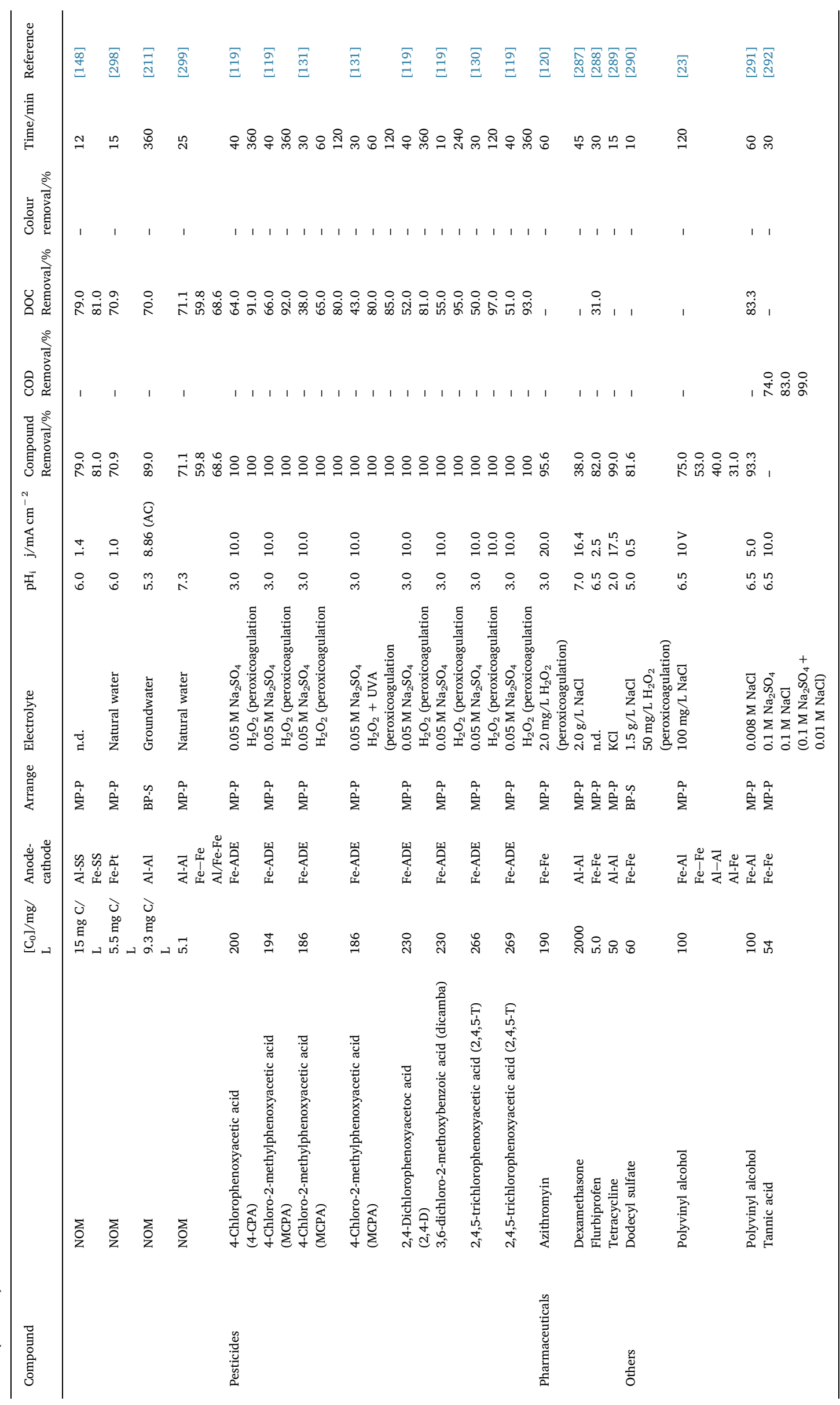


species $\left(\mathrm{Cr}^{3+}, \mathrm{CrO}_{4}{ }^{-}\right.$and $\left.\mathrm{Cr}_{2} \mathrm{O}_{7}{ }^{2-}\right)$ is around $80 \%$ depending on the experimental conditions. It is important to comment that several studies have treated synthetic effluents with higher concentrations of chromium species [49,51,100,102,112,201,219,225,227-232,235-237] whereas that the real effluents have not $>100 \mathrm{ppm}$ of chromium species in solution [222,224,230,234] (see Table 2). On the other hand, it was confirmed that the presence of specific anions promotes higher removal efficiencies for $\mathrm{CrO}_{4}{ }^{-}$and $\mathrm{Cr}_{2} \mathrm{O}_{7}{ }^{2-}$ species [232]. The use of $\mathrm{NaCl}$ or $\mathrm{KCl}$ favors the reduction of concentration of $\mathrm{CrO}_{4}{ }^{-}$and $\mathrm{Cr}_{2} \mathrm{O}_{7}{ }^{2-}$ in the synthetic effluent up to $99 \%$, while that the presence of $\mathrm{NO}_{3}{ }^{-}$and $\mathrm{Al}_{2}(\mathrm{OH})_{n} \mathrm{Cl}_{6-\mathrm{n}}$ promotes a decrease on the efficacy, obtaining removals about $72 \%$ and $80 \%$, respectively. Also, Aber et al. [228] demonstrated that the changes of polarity and combination of electrodes (Al-Fe, Al-Al, $\mathrm{Fe}-\mathrm{Al}, \mathrm{Fe}-\mathrm{Fe}$ ) influenced significantly on the elimination of $\mathrm{CrO}_{4}{ }^{-}$and $\mathrm{Cr}_{2} \mathrm{O}_{7}{ }^{2-}$ when $\mathrm{NaCl}$ as well as $\mathrm{Fe}$ and $\mathrm{Al}$ electrodes were used, being the $\mathrm{Fe}-\mathrm{Fe}$ arrangement the most efficient (99\% of removal).

No significant achievements have been reported about the elimination of cobalt by EC treatment. Shafaei et al. [216] examined the elimination of cobalt at different concentrations (25, 100 and $400 \mathrm{ppm})$ by using a MP-P reactor with $\mathrm{Al}-\mathrm{Al}$ electrodes at $\mathrm{pH} 7$ with $\mathrm{NaCl}$ as supporting electrolyte, obtaining removal efficiencies ranging from $95.5 \%$ to $100 \%$.

In the case of copper, it was efficiently removed under different experimental conditions [28,51,75,214,217,218,221,222,224,225, 238-241], being that the MP-P reactor configurations are preferred for increasing the efficiency (from 95\% to 100\%). No specific electrodes are used because higher efficiencies are frequently achieved (>99\%). The initial concentration is not a significant factor that influences on the removal efficiency as well as the $\mathrm{pH}$ conditions of the effluent. The presence of other anions in the effluent did not also affect the efficacy of EC approach, as observed for other metals [217,239]. For example, the presence of $\mathrm{HCO}_{3}{ }^{-}, \mathrm{SO}_{4}{ }^{2-}, \mathrm{NO}_{3}{ }^{-}$and $\mathrm{Cl}^{-}$did not affect the removal efficiency, attaining frequently about $99 \%$ by using $\mathrm{Fe}-\mathrm{Fe}$ or $\mathrm{Al}-\mathrm{Al}$ electrodes with MP-P reactors [239].

Interestingly, the elimination of iron and lead by EC has been scarcely studied in the last years. However, the efficient removal of lead is possible to be achieved at different experimental conditions $[110,212,242]$, while the iron strongly depends on the electrodes arrangement, mainly the EC reactor and current applied [95,212,243].

The elimination of mercury from water was studied by Nanseu-Njiki et al. [150] achieving higher removal efficiencies using MP-P EC reactor at pH 7.0 by applying lower currents. Meanwhile, nickel was removed from different effluents [28,51,75,221,222,224,239,241] by applying low currents to remove concentration between 50 and $400 \mathrm{mg} / \mathrm{L}$. An interesting work was published by Ferreira and coworkers [239] where the elimination of nickel is achieved in presence of different anions in solution and no significant difference, in terms of removal efficiency, was achieved.

For zinc [28,51,75,212,217,218,224,225,239-242], higher removal efficiencies were achieved independently of the electrodes used ( $\mathrm{Al}$ or $\mathrm{Fe}$ ). The concentration in solution as well as $\mathrm{pH}$ conditions did not affect the efficacy of the process. The same behavior is observed at different electrolytes, but in the case of $\mathrm{Cl}^{-}$, the elimination of zinc decreased when $\mathrm{Al}$ electrodes were used [217]. It can be related to the corrosion phenomenon attained on $\mathrm{Al}$ surface when $\mathrm{Cl}^{-}$is present in solution. These ions promote the dissolution by enhancing pitting. Nevertheless, few authors have indicated that the use of lower currents can be a solution for the fast corrosion phenomenon, retarding the passivation [225]. But in this case, the passivation phenomenon is contrary to the real mechanisms carried out at $\mathrm{Al}$ surface.

\subsection{Organic pollutants}

During the last decade organic pollutants have started to be considered of highly concern and hazardous pollutants as it is stated in the UNESCO's World Water Report [1]. The report of several hazardous effects associated to organics pollution such are toxicity, carcinogenic and mutagenic effects demonstrate that the effluents must be pretreated before their disposal as ineludible environmental requirement $[244,245]$. For the natural organic matter (NOM), it is different because it could not be considered as a pollutant at all. The presence of NOM in water results in specific taste and odor, affecting the quality of the water for reclaim and drinking purpouses. Besides, the presence of NOM in water may reduce considerably the efficiency of different wastewater treatments [246,247] and also cause biofouling on membranes surface [248]. One of the most worring effects of NOM is related with their tend to complex heavy metals affecting their fate and enhancing their distribution as contaminants in natural aquatic environment [249]. EC treatment could be considered an alternative to reduce the fate and the presence of these pollutants in water bodies. Thus, several authors reported high efficiencies on EC removal of organic pollutants and their results are collected in Table 3.

Principally, EC approach has been used to treat synthetic, real or lab solutions containg phenolic compounds [94,118,121,123,124, 250-253], dyes [26,33,37-40,43,71,74,77,79,80,84,85,115,122, 125,254-286], pesticides [31,119,120,130,131], pharmaceuticals [287-289] and others [23,290-292].

In the case of aromatic compounds, the peroxi-coagulation or peroxi-electrocoagulation was employed to eliminate aniline [118,124], 4-chlorophenol [121] and phenol [123]. For aniline and 4chlorophenol, a MP-PEC reactor with Fe-ADE electrodes arrangement was used in $0.05 \mathrm{M} \mathrm{Na}_{2} \mathrm{SO}_{4}$ with $35 \mathrm{mM}$ of $\mathrm{H}_{2} \mathrm{O}_{2}$ under acidic conditions ( $\mathrm{pH}$ about 3.0-3.5). For a solution with $100 \mathrm{mg} / \mathrm{L}$ of aniline, DOC removals, between $74 \%-98 \%$, was achieved, varying the applied current density (from 10 to $45 \mathrm{~mA} \mathrm{~cm}^{-2}$ ) at short electrolysis times (30 min). Meanwhile, when a solution containing $1000 \mathrm{mg} / \mathrm{L}$ of aniline by applying $200 \mathrm{~mA} \mathrm{~cm}^{-2}$ under similar acidic conditions; $95 \%$ of DOC was achieved after $60 \mathrm{~min}$ of electrolysis. Whereas, peroxi-EC treatment of a solution with 4-chlorophenol $(178 \mathrm{mg} / \mathrm{L})$ by applying $10 \mathrm{~mA} \mathrm{~cm}^{-2}$ obtained only $55 \%$ of DOC after $60 \mathrm{~min}$, but when the electrochemical treatment passed to $120 \mathrm{~min}, 80 \%$ of DOC removal was obtained. Mordishahla and co-workers [94] studied the effect of EC reactor and ellectrode used. Based on the results obtained, higher removals of 4nitrophenol (20 mg/L) were observed when Fe-SS and SS-SS electrodes were prefentially used in a solution containing with $300 \mathrm{mg} / \mathrm{L}$ of $\mathrm{NaCl}$ at $\mathrm{pH} 9$ by applying $10 \mathrm{~mA} \mathrm{~cm}{ }^{-2}$ using MP-P, MP-S and BP-S reactors. However, the efficacy decreased when Al-SS configuration was employed. Conversely, when a solution with benzoquinone $(50 \mathrm{mg} / \mathrm{L})$ was treated with a configuration of Al-SS electrodes but with $\mathrm{NaNO}_{3}$ as supporting electrolyte at $\mathrm{pH} 7.0$, no passivation was observed, removing $90 \%$ of organic compound [250]. Dimethyl phthalate was also efectively eliminate $(100 \%)$ from synthetic effluent $(100 \mathrm{mg} / \mathrm{L})$ with a MP-P reactor with SS-SS electrodes in presence of $\mathrm{Cl}^{-}$ions in solution $(1500 \mathrm{mg} / \mathrm{L})$ at $\mathrm{pH} 6$ by applying $22.5 \mathrm{~mA} \mathrm{~cm}^{-2}$ [251].

Table 3 summarizes the main operating conditions for removing dyes from effluents, emphasizing the percentage of colour removal and organic matter decay (in terms of COD, DOC or organic compound) for selected synthetic dyes wastewaters under optimized EC conditions by using preferentially monopolar and bipolar $\mathrm{Al}, \mathrm{Fe}$ or steel electrodes. The effect of initial $\mathrm{pH}$, retention time and current density as function of decolourization efficiency for $250 \mathrm{~mL}$ of $50 \mathrm{mg} \mathrm{dm}^{-3}$ solutions of the azo dye Basic Red 43 in $\mathrm{NaCl}$ (conductivity $8 \mathrm{mS} \mathrm{cm}^{-1}$ ) using an unstirred Fe-SS reactor with electrodes of $50 \mathrm{~mm} \times 50 \mathrm{~mm} \times 3 \mathrm{~mm}$ in dimension operating in batch mode [37], achieving a maximum colour removal of approximately $95 \%$ at $\mathrm{pH}$ 5.5-8.5 (see Table 3). Under these conditions, the majority of electrogenerated $\mathrm{Fe}^{3+}$ forms $\mathrm{Fe}(\mathrm{OH})_{3}$ flocs that can remove rapidly the dye molecules by complexation or electrostatic attraction, followed by coagulation. In contrast, at $\mathrm{pH}<3.0$ soluble $\mathrm{Fe}^{3+}$ is the dominant species and $\mathrm{Fe}(\mathrm{OH})_{3}$ flocs are quite poorly produced, whereas at $\mathrm{pH}>9.0$ a part of $\mathrm{Fe}(\mathrm{OH})_{3}$ is solubilized as $\mathrm{Fe}$ $(\mathrm{OH})_{4}{ }^{-}$and lower amount of dye can be separated.

Other important parameter is the retention time or total electrolysis 
time of the dye wastewater in the EC reactor. According Daneshvar and co-workers [37], a minimum retention time of $5 \mathrm{~min}$ is needed to reach the highest decolourization efficiency of a $50 \mathrm{mg} \mathrm{dm}^{-3}$ Basic Red 43 solution at pH 5.8 and $6 \mathrm{~mA} \mathrm{~cm}^{-2}$, and under these conditions sufficient $\mathrm{Fe}(\mathrm{OH})_{3}$ flocs are produced to remove efficiently the dyestuff. Daneshvar et al. [33] also described an enhancement of colour removal with increasing stirring rate up to $200 \mathrm{rpm}$ during the EC treatment of $250 \mathrm{~mL}$ of $50 \mathrm{mg} \mathrm{dm}^{-3}$ of the azo dye Acid Orange 7 by using a MP-P with $\mathrm{Fe}-\mathrm{Fe}$ electrodes because aggregation of flocs is gradually favoured and consequently, the coagulation is easily achieved, removing $98 \%$ of dye and $84 \%$ of COD. Conversely, higher stirring rates promote an advanced degradation of flocs. Mollah et al. [257] used a flow cell of $450 \mathrm{~mL}$ volume with SS electrodes in a BS-P reactor at $\mathrm{pH} 7.3$ to treat a solution of $30 \mathrm{mg} \mathrm{dm}^{-3}$ Acid Orange 7 with $4 \mathrm{~g} / \mathrm{L}$ of $\mathrm{NaCl}$, achieving $98.5 \%$ of dye decay and 98.5 of colour removal by applying $16 \mathrm{~mA} \mathrm{~cm}^{-2}$ at $25^{\circ} \mathrm{C}$.

Current density controls the generation rate of iron ions, the growth of $\mathrm{Fe}(\mathrm{OH})_{3}$ flocs and the rate and size of $\mathrm{H}_{2}$ bubbles evolved. The control of this operating parameter determines the EC treatment time and energy cost of a dyestuff effluent. This behavior was also determined by Daneshvar and co-workers [37] during the treatment of a $50 \mathrm{mg} \mathrm{dm}^{-3}$ Basic Red 43 at $\mathrm{pH} 5.8$ by applying $6 \mathrm{~mA} \mathrm{~cm}^{-2}$ obtaining $95 \%$ of colour removal with $4.7 \mathrm{kWh}$ (kg dye) ${ }^{-1}$ energy cost. When high current densities were applied, moderate decolourization efficiency was achieved, but the cost dramatically decreased to ca. $20 \mathrm{kWh}$ ( $\mathrm{kg}$ dye $)^{-1}$ at $14 \mathrm{~mA} \mathrm{~cm}^{-2}$. Under similar conditions to those used to treat Basic Red 43; Basic Blue 3 was removed by applying $8 \mathrm{~mA} \mathrm{~cm}^{-2}$ attaining $90 \%$ of colour removal [37] and for Acid Yellow 23, at $11.2 \mathrm{~mA} \mathrm{~cm}^{-2}$ with $98 \%$ of colour removal [40].

An inspection of Table 3 reveals the existence of a poor DOC or COD decay for several dyes treatments by EC, even when higher decolourization efficiency is achieved under optimized conditions. Unfortunately, limited information is known in EC about by-products formed during the treatment. In the case of Acid Orange 7, for example, it has been demonstrated that its azo bond is reduced and broken, probably by oxidation with electrogenerated $\mathrm{Fe}^{2+}$ and/or hypochlorite ion, to give 1-amino-2-naphtol and sulphanilic acid salt, being desorbed the former from the sludge formed [33].

The influence of different tank reactors on the comparative EC treatment in batch mode of $250 \mathrm{~mL}$ of a solution containing until $150 \mathrm{mg} \mathrm{dm}^{-3}$ of the azo dye Acid Red 14 in the presence of $10 \mathrm{~g} \mathrm{dm}^{-3}$ $\mathrm{NaCl}$ at pH 6-9, has also been investigated [260]. Experimental results showed that the simple cell with two monopolar electrodes is less effective, while the stirred cell with four monopolar electrodes gives slightly higher decolourization efficiency than that with two monopolar and two bipolar electrodes. Under optimized conditions by applying $8 \mathrm{~mA} \mathrm{~cm}^{-2}$, colour removal of about $93 \%$ and COD decay of $85 \%$ at $25{ }^{\circ} \mathrm{C}$ were obtained, indicating that the EC process is practically unaffected by the cell configuration.

Dye concentration, electrolyte composition, current density, electrodes and operation mode also affect the coagulation mechanisms of Acid Black 1 [254], Acid Brown 14 [256], Acid Orange 7 [258,259], Acid Red 14 [261], Acid Red 131 [262], Acid Yellow 23 [77], Amino Black 10B [265], Crystal Violet [268], Direct Red 81 [84], Indigo Carmine [279], Reactive Black 5 [85], Reactive Red 43 [285], Remazol Brillant Yellow GL [38], Rhodamine 6G [115] and Remazol Red RB [38]. The colour removal suffers a continuous decay for increasing concentration of dye because polymeric aluminum cations and $\mathrm{Al}(\mathrm{OH})_{3}$ flocs can only retain a stoichiometric amount of the dye in excess in the solution. This phenomenon is much more significant with $\mathrm{NaCl}$ than with $\mathrm{Na}_{2} \mathrm{SO}_{4}$ as background electrolyte, probably due to the existence of a much larger adsorption of $\mathrm{Cl}^{-}$on $\mathrm{Al}(\mathrm{OH})_{3}$ that strongly inhibits dye removal.

The effect of operating parameters on the decolourization efficiency of other dyes by EC with $\mathrm{Al}$ has been extensively studied. Optimized conditions for selected compounds leading to about $98 \%$ of colour removal are also collected in Table 3. The large influence of $\mathrm{pH}$ on decolourization efficiency has been corroborated by Kobya et al. [43] when electrolyzed $250 \mathrm{~mL}$ of Levafix Orange and Remazol Red 3B solutions with $\mathrm{NaCl}$ between $\mathrm{pH} 3-11$ at $25^{\circ} \mathrm{C}$ using MP-P reactor. These authors found higher colour removal for $\mathrm{pH}<6.5$ than neutral and alkaline conditions owing to the predominance of precipitation mechanisms via monomeric and polymeric aluminum cations, along with decay in colour removal and energy consumption.

Merzouk et al. [272] proposed a model to evaluate the decay in absorbance, turbidity, COD and TOC of single and mixed dye wastes just assuming an adsorption-desorption equilibrium between matter and $\mathrm{Al}(\mathrm{OH})_{3(\mathrm{~s})}$. This model allowed explaining the EC treatment of $2 \mathrm{~L}$ of a real textile effluent of $\mathrm{pH} 7$ using a flow plant equipped with a tank reactor containing two $\mathrm{Al}$ electrodes of $105 \mathrm{~cm}^{2}$ area operating in batch between 4 and $20 \mathrm{~mA} \mathrm{~cm}^{-2}$ at liquid flow rate of $0.15 \mathrm{~L} \mathrm{~min}^{-1}$. The amount of $\mathrm{Al}$ species dissolved in the effluent was the limiting factor of the process regardless of applied $j$ and thus, about $65 \%$ colour removal with ca. 70\% COD and TOC decays, along with overall disappearance of turbidity, were obtained as maximal, after producing 250-350 $\mathrm{mg} \mathrm{dm}^{-3}$ of soluble aluminum.

Results of Table 3 confirm that EC with $\mathrm{Al}$ yielded excellent colour removal, between 90\%-99\%, for Acid Black 52 and Acid Yellow 220 [255], Acid Black 172 [293] and Basic Green 4 [294,295]. The decolorization efficiency of the two former dyes in single and binary solutions was followed by electrolyzing $250 \mathrm{~mL}$ of $200-600 \mathrm{mg} \mathrm{dm}^{-3}$ of substrates up to $8 \mathrm{~g} \mathrm{dm}^{-3} \mathrm{NaCl}$ within $\mathrm{pH}$ range $2.5-10$ between 1.0 and $12 \mathrm{~mA} \mathrm{~cm}^{-2}$ for $7.5 \mathrm{~min}$.

Similar colour removals were found for single and binary solutions with dye contents $<400 \mathrm{mg} \mathrm{dm}^{-3}$ at optimum $\mathrm{pH} 5$ owing to the coagulation of the major part of monomeric-Al species from reaction (20). The increase in $j$ accelerated the decolorization of both dyes because of the release of more soluble $\mathrm{Al}$ species, but higher amounts of $\mathrm{NaCl}$ caused primordially a rise in conductivity with a very low effect on colour removal.

For the EC process of Acid Black 172, Taheri et al. [293] applied the response surface methodology (RSM) to analyze the decolorization process with four independent variables like initial dye content up to $600 \mathrm{mg} \mathrm{dm}^{-3}$, initial $\mathrm{pH}$ between 4 and 10, applied $j$ between 2.1 and $14.5 \mathrm{~mA} \mathrm{~cm}^{-2}$ and electrolysis time between 3 and $15 \mathrm{~min}$. The mathematical correlation of such variables with the percentage of colour removal was developed using a central composite design consisting of 31 experiments with 16 factorial points, 8 axial points and 7 replicates at the central point. About $90 \%$ of correlation between experimental and model values was obtained and the optimized data determined by this procedure are collected in Table 1 . In the case of Basic Green 4, Singh et al. [294,295] used the change in zeta potential with operating variables to find optimum values of $99 \%$ colour removal and $82 \%$ COD and $63 \%$ TOC decays with $2.48 \mathrm{kWh}(\mathrm{kg} \mathrm{TOC})^{-1}$ energy consumption when a $100 \mathrm{mg} \mathrm{dm}^{-3}$ dye solution at $\mathrm{pH} 6.2$ was treated at $11.7 \mathrm{~mA} \mathrm{~cm}^{-2}$ for $45 \mathrm{~min}$. EDX analysis revealed that the scum (produced as a layer of gas bubbles with floated particles) contained a more content of carbon, whereas the sludge contained larger proportion of aluminum. These findings were justified assuming that the EC process involves: (i) the generation of small organic products that are collected in the scum by electroflotation and (ii) the coagulation of longer organics with $\mathrm{Al}(\mathrm{OH})_{3}$ in the sludge.

Most comparative studies with pure synthetic dyes have been performed with reactive, disperse and acid products utilized in the textile industry. Kim et al. [71] reported the superiority of Fe for decolourization efficiency when treating the Reactive Blue 49 and Reactive Yellow 84 in front the Disperse Blue 106 and Disperse Yellow 54, whereas the opposite tendency was preferred by using Al. On the other hand, Yang and McGarrahan [263] compared the decolourization rate of the antraquinone dye Reactive Blue 19 and the azo dyes Acid Red 226 and Disperse Yellow 218 to attain $98 \%$ colour removal. For a steel anode, it decayed in the order: reactive $>$ acid $>$ disperse, and for $\mathrm{Al}$, 
Table 4

Electrocoagulation treatment of actual effluents by electrocoagulation technologies.

\begin{tabular}{|c|c|c|c|c|c|c|c|c|c|c|c|}
\hline Effluent & $\begin{array}{l}\text { Anode- } \\
\text { cathode }\end{array}$ & Arrange & $\mathrm{pH}_{\mathrm{i}}$ & $\mathrm{j} / \mathrm{mA} \mathrm{cm}^{-2}$ & $\begin{array}{l}\text { COD } \\
\text { removal/ } \%\end{array}$ & $\begin{array}{l}\text { DOC } \\
\text { removal/\% }\end{array}$ & $\begin{array}{l}\text { Colour } \\
\text { removal/\% }\end{array}$ & Turbidity/\% & $\begin{array}{l}\text { Metals } \\
\text { removal/\% }\end{array}$ & Time/min & Reference \\
\hline Almond Industry & $\mathrm{Al}-\mathrm{Fe}$ & MP-P & 6.1 & 10.0 & 81.0 & 74.0 & 99.6 & 99.7 & - & 25 & {$[300]$} \\
\hline \multirow[t]{2}{*}{ Baker's Yeast wastewater } & $\mathrm{Al}-\mathrm{Al}$ & MP-P & 6.5 & 7.0 & 71.0 & 53.0 & - & 90.0 & - & 50 & {$[301]$} \\
\hline & $\mathrm{Fe}-\mathrm{Fe}$ & & 7.0 & & 69.0 & 52.0 & - & 56.0 & - & & \\
\hline Baker's Yeast wastewater & $\mathrm{Al}-\mathrm{Al}$ & MP-P & 4.0 & 1.3 & 48.0 & 49.0 & 88.0 & - & - & 30 & {$[302]$} \\
\hline Bilge water & $\mathrm{Al}-\mathrm{Fe}$ & MP-P & 4.0 & 600 & - & - & - & - & 99.0 & 30 & [303] \\
\hline Biodiesel wastewater & $\mathrm{Al}-\mathrm{Gr}$ & MP-P & 6.1 & 20.8 & 55.4 & - & - & - & - & 23.5 & {$[304]$} \\
\hline Biodiesel wastewater & $\mathrm{Al}-\mathrm{Al}$ & MP-P & 9.5 & 18.6 & 45.0 & - & - & - & - & 30 & {$[305]$} \\
\hline Carwash wastewaters & SS-SS & MP-P & 6.4 & 2.0 & 97.0 & - & - & - & - & 100 & {$[306]$} \\
\hline Cheese whey wastewater & $\mathrm{Fe}-\mathrm{Fe}$ & MP-P & 4.5 & 60 & - & 86.4 & - & - & - & 20 & [111] \\
\hline $\begin{array}{l}\text { Chemical Mechanical Polishing } \\
\text { (CMP) wastewater }\end{array}$ & $\mathrm{Al}-\mathrm{Fe}$ & MP-P & 7.0 & 2.5 & 75.0 & - & - & 96.5 & 99.0 & 100 & {$[238]$} \\
\hline CMP wastewater & $\mathrm{Al}-\mathrm{Fe}$ & MP-P & 7.5 & 9.3 & 85.0 & - & - & - & 99.0 & 30 & {$[308]$} \\
\hline CMP wastewater & $\mathrm{Al}-\mathrm{Al}$ & BP-S & 8.5 & n.d. & - & - & - & 100 & 100 & 10 & [309] \\
\hline CMP wastewater & $\mathrm{Fe}-\mathrm{Fe}$ & MP-P & 6.0 & 12.5 & 75.0 & - & - & - & 99.0 & 50 & {$[310]$} \\
\hline Cigarette industry wastewater & $\mathrm{Fe}-\mathrm{Fe}$ & MP-P & 8.1 & 10.9 & 56.0 & - & - & - & - & 300 & [311] \\
\hline Coal seam water & $\mathrm{Al}-\mathrm{Al}$ & MP-P & 7.0 & 0.8 & - & 54.6 & 100 & 63.0 & 99.0 & 30 & [312] \\
\hline $\begin{array}{l}\text { Cookies and pasta processing } \\
\text { wastewater }\end{array}$ & $\mathrm{Al}-\mathrm{Al}$ & MP-P & 4.0 & 18.2 & 90.0 & - & 57.0 & - & - & 60 & [128] \\
\hline Dairy effluents & $\mathrm{Fe}-\mathrm{Fe}$ & MP-P & 7.0 & 0.6 & 98.0 & - & - & - & - & 1 & [313] \\
\hline Dairy effluents & Al-Al & MP-P & 7.0 & 4.3 & 61.0 & - & - & 100 & - & 25 & [314] \\
\hline Dairy effluents & $\begin{array}{l}\mathrm{Fe}-\mathrm{Al} \\
\left(\mathrm{H}_{2} \mathrm{O}_{2}\right)\end{array}$ & MP-P & 7.0 & 15.0 & 79.2 & - & - & - & - & 30 & [315] \\
\hline Distillery effluent & Al-SS & MP-P & 6.2 & 18.2 & 80.1 & - & 100 & 99.0 & - & 60 & {$[316]$} \\
\hline Distillery effluent & $\mathrm{Al}-\mathrm{Al}$ & MP-P & 6.0 & 28.4 & 41.9 & - & - & - & - & 10 & [317] \\
\hline Distillery effluent & SS-SS & MP-P & 6.5 & 14.7 & 61.6 & - & 98.4 & - & - & 130 & [318] \\
\hline Distillery effluent & $\mathrm{Al}-\mathrm{Al}$ & MP-P & 3.0 & 3.0 & 70.0 & - & - & - & - & 120 & [319] \\
\hline Distillery effluent & $\mathrm{Fe}-\mathrm{Fe}$ & MP-P & 4.0 & 20.0 & 61.0 & 25.0 & - & 89.0 & - & 120 & {$[320]$} \\
\hline \multirow[t]{3}{*}{ Distillery effluent } & $\mathrm{Al}-\mathrm{Al}$ & MP-P & 3.0 & 18.7 & 81.3 & - & - & - & - & 120 & {$[321]$} \\
\hline & $\mathrm{Al}-\mathrm{Fe}$ & & & & 71.8 & & & & & & \\
\hline & $\mathrm{Fe}-\mathrm{Fe}$ & & & & 52.4 & & & & & & \\
\hline Domestic wastewater & $\begin{array}{l}\mathrm{Fe}-\mathrm{Fe} \\
\left(\mathrm{H}_{2} \mathrm{O}_{2}\right)\end{array}$ & MP-P & 7.2 & 1.7 & 60.0 & - & - & - & - & 15 & [322] \\
\hline \multirow[t]{2}{*}{ Dyebath effluent } & $\mathrm{Fe}-\mathrm{Fe}$ & MP-P & 5.0 & 22.0 & 93.0 & - & 99.0 & - & - & 60 & {$[323]$} \\
\hline & $\mathrm{Al}-\mathrm{Al}$ & & & & 86.0 & & 95.0 & & & 90 & \\
\hline \multirow[t]{3}{*}{ Egg processing wastewater } & $\mathrm{Fe}-\mathrm{Fe}$ & MP-P & 7.0 & 18.5 & 95.0 & - & - & 97.0 & - & 14 & {$[324]$} \\
\hline & $\mathrm{Al}-\mathrm{Al}$ & & & & 95.0 & & & 97.0 & & & \\
\hline & SS-SS & & & & 92.0 & & & 96.0 & & & \\
\hline Food-processing wastewater & $\mathrm{Al}-\mathrm{Al}$ & MP-P & 4.0 & 1.8 & 88.0 & - & - & - & - & 40 & {$[325]$} \\
\hline Gelatin production effluent & $\mathrm{Al}-\mathrm{Al}$ & MP-P & 5.9 & 54.5 & - & 54.7 & - & - & - & 300 & {$[326]$} \\
\hline \multirow{3}{*}{$\begin{array}{l}\text { Hospital operation theatre } \\
\text { effluent }\end{array}$} & $\mathrm{Fe}-\mathrm{Fe}$ & MP-P & 6.8 & 12.2 & 100 & - & - & - & - & 75 & {$[327]$} \\
\hline & $\mathrm{Fe}-\mathrm{Al}$ & & & & 95.0 & - & - & - & - & & \\
\hline & $\mathrm{Al}-\mathrm{Al}$ & & & & 90.0 & - & - & - & - & & \\
\hline Industrial wastewater & $\mathrm{Al}-\mathrm{Al}$ & MP-P & 7.0 & 11.0 & 95.0 & - & 99.0 & 99.0 & - & 10 & {$[328]$} \\
\hline Industrial wastewater & $\mathrm{Al}-\mathrm{Al}$ & MP-P & 7.0 & 8.0 & 70.0 & - & - & 90.0 & - & 70 & [329] \\
\hline Landfill leachate & $\mathrm{Fe}-\mathrm{Fe}$ & MP-P & 7.0 & 5.0 & 49.8 & - & - & 69.7 & - & 90 & {$[330]$} \\
\hline Landfill leachate & $\mathrm{Al}-\mathrm{Al}$ & MP-P & 6.6 & 15.9 & 45.0 & - & 60.0 & - & - & 30 & {$[331]$} \\
\hline \multirow[t]{2}{*}{ Landfill leachate } & $\mathrm{Al}-\mathrm{Al}$ & MP-P & 8.0 & 25.0 & 70.0 & - & 56.0 & 60.0 & - & 30 & {$[332]$} \\
\hline & $\mathrm{Fe}-\mathrm{Fe}$ & & & & 68.0 & & 28.0 & 16.0 & & & \\
\hline Landfill leachate & $\mathrm{Fe}-\mathrm{Fe}$ & MP-P & 6.5 & 30.0 & 68.5 & - & - & - & - & 180 & [333] \\
\hline Landfill leachate & $\mathrm{Al}-\mathrm{Al}$ & MP-P & 8.0 & 9.5 & - & - & 80.0 & 82.8 & - & 135 & [334] \\
\hline Laundry wastewater & $\mathrm{Al}-\mathrm{Al}$ & BP-S & 5.5 & 24.0 & 70.0 & - & - & 90.0 & - & 10 & {$[335]$} \\
\hline Laundry wastewater & $\mathrm{Al}-\mathrm{Al}$ & MP-P & 7.5 & 3.7 & 62.0 & - & - & - & - & 40 & {$[101]$} \\
\hline \multirow[t]{2}{*}{ Laundry wastewater } & $\mathrm{Al}-\mathrm{Al}$ & MP-P & 7.0 & 8.8 & 25.0 & - & 30.0 & 35.0 & - & 45 & [103] \\
\hline & & BP-P & & & 90.0 & - & 92.0 & 94.0 & - & & \\
\hline \multirow[t]{4}{*}{ Oily bilgewater } & $\mathrm{Al}-\mathrm{Al}$ & MP-P & 7.1 & 13.6 & 74.7 & - & - & - & - & 90 & {$[336]$} \\
\hline & $\mathrm{Al}-\mathrm{Al}$ & BP-P & & & 73.6 & & & - & & & \\
\hline & $\mathrm{Fe}-\mathrm{Fe}$ & MP-P & & & 77.4 & & & 98.4 & & & \\
\hline & $\mathrm{Fe}-\mathrm{Fe}$ & BP-P & & & 76.6 & & & - & & & \\
\hline \multirow[t]{2}{*}{ Olive oil mill wastewater } & $\mathrm{Al}-\mathrm{Al}$ & MP-P & 6.0 & 40.0 & 52.0 & - & 97.0 & - & - & 30 & {$[337]$} \\
\hline & $\mathrm{Fe}-\mathrm{Fe}$ & & & & 42.0 & & 93.0 & & & & \\
\hline Olive oil mill wastewater & $\mathrm{Al}-\mathrm{Al}$ & MP-P & 4.2 & 25.0 & 70.0 & - & 100 & - & - & 15 & {$[338]$} \\
\hline Olive oil mill wastewater & $\mathrm{Al}-\mathrm{Al}$ & MP-P & 6.0 & 40.0 & 58.7 & - & - & - & - & 45 & [339] \\
\hline Olive oil mill wastewater & Zn-SS & MP-P & 3.2 & 25.0 & 20.9 & - & - & - & - & 40 & {$[46]$} \\
\hline Olive packaging industry & $\mathrm{Al}-\mathrm{Fe}$ & MP-P & 4.8 & 25.0 & 40.0 & - & 100 & - & - & 50 & [340] \\
\hline Paint manufacturing & $\mathrm{Fe}-\mathrm{Fe}$ & MP-P & 7.0 & 3.5 & 93.0 & 88.0 & - & - & - & 15 & {$[34]$} \\
\hline industry & $\mathrm{Al}-\mathrm{Al}$ & & & & 94.0 & 89.0 & - & - & - & & \\
\hline Palm oil mill wastewater & $\mathrm{Al}-\mathrm{Al}$ & MP-P & 4.3 & 0.67 & 30.4 & 72.0 & - & 70.0 & 100 & 360 & [342] \\
\hline Paper industry black liquor & $\mathrm{Al}-\mathrm{Al}$ & MP-P & 7.0 & 14.0 & 98.0 & - & 99.0 & - & - & 50 & [343] \\
\hline $\begin{array}{l}\text { Paper industry bleaching } \\
\text { effluent }\end{array}$ & $\mathrm{Al}-\mathrm{Al}$ & MP-P & 7.0 & 15.0 & 90.0 & - & 94.0 & - & - & 30 & {$[344]$} \\
\hline Paper mill effluents & $\mathrm{Al}-\mathrm{Al}$ & MP-P & n.d. & 7.5 & 4.8 & 80.0 & - & - & - & 7 & {$[152]$} \\
\hline Paper mill effluents & $\mathrm{Fe}-\mathrm{Fe}$ & MP-P & 7.5 & 4.8 & 55.0 & - & - & - & - & 7.5 & {$[345]$} \\
\hline & $\mathrm{Al}-\mathrm{Al}$ & & & & 75.0 & & & & & & \\
\hline
\end{tabular}


Table 4 (continued)

\begin{tabular}{|c|c|c|c|c|c|c|c|c|c|c|c|}
\hline Effluent & $\begin{array}{l}\text { Anode- } \\
\text { cathode }\end{array}$ & Arrange & $\mathrm{pH}_{\mathrm{i}}$ & $\mathrm{j} / \mathrm{mA} \mathrm{cm}^{-2}$ & $\begin{array}{l}\text { COD } \\
\text { removal/\% }\end{array}$ & $\begin{array}{l}\text { DOC } \\
\text { removal/\% }\end{array}$ & $\begin{array}{l}\text { Colour } \\
\text { removal/\% }\end{array}$ & Turbidity/\% & $\begin{array}{l}\text { Metals } \\
\text { removal/\% }\end{array}$ & Time/min & Reference \\
\hline \multirow[t]{4}{*}{ Paper mill effluents } & $\mathrm{Al}-\mathrm{Al}$ & MP-P & 6.0 & 70 & 72.0 & - & 88.0 & - & - & 60 & {$[346]$} \\
\hline & $\mathrm{Al}-\mathrm{Fe}$ & & & & 79.0 & - & 82.0 & - & - & & \\
\hline & $\mathrm{Fe}-\mathrm{Al}$ & & & & 80.0 & - & 65.0 & - & - & & \\
\hline & $\mathrm{Fe}-\mathrm{Fe}$ & & & & 85.0 & - & 50.0 & - & - & & \\
\hline \multirow[t]{2}{*}{ 5Paper mill effluents } & $\mathrm{Fe}-\mathrm{Fe}$ & MP-P & 7.7 & 10.0 & 32.0 & 24.0 & - & - & - & 90 & [209] \\
\hline & $\mathrm{Al}-\mathrm{Al}$ & & & & 68.0 & 46.0 & & & & & \\
\hline \multirow[t]{2}{*}{ Petrochemical wastewater } & $\mathrm{Al}-\mathrm{Fe}$ & MP-P & 7.6 & 15.0 & 78.0 & - & - & 80.0 & - & 10 & {$[347]$} \\
\hline & Fe-Al & & & & 78.0 & & & 80.0 & & & \\
\hline $\begin{array}{l}\text { Petroleum refinery sulfidic } \\
\text { spent caustic wastes }\end{array}$ & $\mathrm{Fe}-\mathrm{Fe}$ & MP-P & 9.0 & 21.2 & 80.0 & - & - & - & 95.0 & 30 & [348] \\
\hline Petroleum refinery wastewater & $\mathrm{Al}-\mathrm{Al}$ & MP-P & 8.0 & 13.0 & 70.0 & - & - & - & - & 90 & [349] \\
\hline Plugboard wastewater & $\begin{array}{l}\mathrm{Fe}-\mathrm{Fe} \\
\left(\mathrm{H}_{2} \mathrm{O}_{2}\right)\end{array}$ & MP-P & 3.0 & 10.4 & 76.0 & - & - & - & - & 30 & [350] \\
\hline Potato chips manufacturing & $\mathrm{Al}-\mathrm{Al}$ & MP-P & 5.0 & 20.0 & 60.0 & - & - & - & 98.0 & 40 & [99] \\
\hline Pulp mill effluents & $\mathrm{Fe}-\mathrm{Fe}$ & MP-P & 5.0 & 14.3 & 26.3 & - & - & 99.0 & - & 1 & {$[351]$} \\
\hline \multirow[t]{2}{*}{ Restaurant wastewater } & $\mathrm{Fe}-\mathrm{Fe}$ & BP-S & 6.6 & 8.0 & 95.0 & - & - & - & - & 20 & {$[352]$} \\
\hline & $\mathrm{Al}-\mathrm{Al}$ & & & & 97.0 & - & - & - & - & & \\
\hline \multirow[t]{2}{*}{ Slaughterhouse effluent } & $\mathrm{Fe}-\mathrm{Fe}$ & MP-P & 3.0 & 15.0 & 86.0 & - & - & - & - & 25 & {$[353]$} \\
\hline & $\mathrm{Al}-\mathrm{Al}$ & & & & 93.0 & & & & & & \\
\hline \multirow[t]{2}{*}{ Slaughterhouse effluent } & $\mathrm{Fe}-\mathrm{Fe}$ & MP-P & 3.0 & 15.0 & 98.0 & - & - & - & - & 25 & {$[354]$} \\
\hline & $\mathrm{Al}-\mathrm{Al}$ & & & & 93.0 & & & & & & \\
\hline Slaughterhouse effluent & $\mathrm{Fe}-\mathrm{Fe}$ & MP-P & 6.1 & 2.7 & 82.0 & 50.0 & - & 100 & 90.0 & 75 & {$[355]$} \\
\hline Slaughterhouse effluent & $\mathrm{Al}-\mathrm{Al}$ & MP-P & 4.0 & 1.0 & 85.0 & - & - & - & 98.0 & 20 & [356] \\
\hline \multirow{3}{*}{$\begin{array}{l}\text { Surfactant-aided soil- } \\
\text { remediation effluents }\end{array}$} & $\mathrm{Al}-\mathrm{Al}$ & MP-P & 1.4 & 7.5 & 95.0 & - & - & 98.0 & - & 30 & [357] \\
\hline & & & & & & & & & & 30 & \\
\hline & & & & & & & & & & 30 & \\
\hline Tannery effluent & $\mathrm{Fe}-\mathrm{Fe}$ & MP-P & 6.8 & 25.0 & 70.0 & - & - & - & 80.0 & 20 & {$[358]$} \\
\hline Tannery effluent & $\begin{array}{l}\mathrm{Fe}-\mathrm{Fe} \text { and } \\
\mathrm{Al}-\mathrm{Al}\end{array}$ & MP-P & 7.0 & 7.9 & 68.0 & 55.1 & 84.3 & - & - & 60 & [359] \\
\hline Tannery effluent & $\mathrm{Fe}-\mathrm{Fe}$ & MP-P & 7.8 & 68.0 & 56.0 & - & - & 99.0 & 99.0 & 40 & {$[360]$} \\
\hline Tannery effluent & $\mathrm{Fe}-\mathrm{Fe}$ & MP-P & 3.0 & 35.0 & 82.0 & - & - & - & - & 10 & {$[361]$} \\
\hline Tannery effluent & $\mathrm{Fe}-\mathrm{Fe}$ & MP-P & 4.1 & $1.5 \mathrm{~A}$ & 25.0 & - & - & 94.3 & 24.5 & 20 & {$[362]$} \\
\hline Textile effluent & $\mathrm{Fe}-\mathrm{Fe}$ & MP-P & 8.0 & 9.3 & 55.0 & - & - & - & - & 10 & [29] \\
\hline \multirow[t]{2}{*}{ Textile effluent } & $\mathrm{Fe}-\mathrm{Fe}$ & MP-P & 7.0 & 10.0 & 78.0 & - & - & 99.0 & - & 10 & {$[275]$} \\
\hline & $\mathrm{Al}-\mathrm{Al}$ & & 4.0 & & 60.0 & - & - & 98.0 & - & & \\
\hline Textile effluent & $\mathrm{Al}-\mathrm{Al}$ & MP-P & 7.0 & 10.0 & 50.0 & - & - & - & - & 10 & {$[363]$} \\
\hline \multirow[t]{2}{*}{ Textile effluent } & $\mathrm{Fe}-\mathrm{Fe}$ & MP-P & 7.0 & 3.0 & 65.0 & - & - & 83.0 & - & 15 & {$[364]$} \\
\hline & $\mathrm{Al}-\mathrm{Al}$ & & 5.0 & & 63.0 & & & 80.0 & & & \\
\hline \multirow[t]{2}{*}{ Textile effluent } & $\mathrm{Fe}-\mathrm{Fe}$ & MP-P & 7.0 & 10.0 & 92.5 & - & - & - & - & 60 & [34] \\
\hline & $\mathrm{Al}-\mathrm{Al}$ & & 6.0 & & 92.1 & - & - & - & - & & \\
\hline \multirow[t]{2}{*}{ Transport container wastewater } & $\mathrm{Fe}-\mathrm{Fe}$ & MP-P & 10 & 10.0 & 79.5 & - & 99.7 & 99.5 & - & 30 & {$[365]$} \\
\hline & $\mathrm{Al}-\mathrm{Al}$ & & & & 76.3 & - & 99.1 & 99.8 & - & 60 & \\
\hline $\begin{array}{l}\text { Vegetable oil refinery } \\
\text { wastewater }\end{array}$ & $\mathrm{Al}-\mathrm{Al}$ & MP-P & 7.0 & 35.0 & 98.9 & - & - & - & - & 90 & [366] \\
\hline $\begin{array}{l}\text { Wet-spun acrylic fibers } \\
\text { manufacturing wastewater }\end{array}$ & $\mathrm{Fe}-\mathrm{Fe}$ & MP-P & 5.0 & 35.7 & 60.0 & 44.0 & - & - & - & 100 & {$[367]$} \\
\hline Yogurt industry wastewater & $\mathrm{Fe}-\mathrm{Fe}$ & MP-P & 4.5 & 30.0 & 84.0 & - & - & - & - & 90 & [368] \\
\hline
\end{tabular}

in the sequence: acid $>$ reactive $>$ disperse. For $250 \mathrm{~mL}$ of $50 \mathrm{~g} \mathrm{dm}^{-3}$ of the azo dye Acid Yellow 23 in $\mathrm{NaCl}$ (conductivity $16.5 \mathrm{mS} \mathrm{cm}^{-1}$ ) at $\mathrm{pH} 6.0$ treated with stirred Fe-SS and Al-SS cells, a better performance was found for $\mathrm{Al}$ with almost $98 \%$ of colour removal and $69 \%$ of COD decay by applying $11.25 \mathrm{~mA} \mathrm{~cm}^{-2}$ during $5 \mathrm{~min}$, since a quite poor colour reduction $<25 \%$ was obtained for Fe [40]. A positive effect on the decolourization efficiency of Acid Yellow 23 has also been reported by Mordishahla et al. [39] when Fe and $\mathrm{Al}$ electrodes are combined in stirred tank reactors with MP-P and BS-P electrodes in comparison with the same electrochemical cells only containing one electrode material. Al was also found superior to $\mathrm{Fe}$ for the decolourization of $1.5 \mathrm{~L}$ of a $1 \mathrm{~g} \mathrm{dm}^{-3}$ Acid Yellow 220 solution in $2 \mathrm{~g} / \mathrm{L} \mathrm{NaCl}$ of pH 5.0 using the system of MP-P [255].

Recent studies on the decolourization and decontamination of dyestuff solutions have been carried out with bench-scaled tank reactors equipped with parallel monopolar electrodes operating in batch mode $[85,125,254,265,270]$. Each of these electrodes is an electrical contact to the power supply and their two active faces have the same polarity. Table 3 highlights that the removal of dyes depends on different operating parameters and most of these trials were performed at
pH 6-8 and under these conditions, $\mathrm{Fe}(\mathrm{OH})_{3}$ flocs were formed in larger proportion and the dye molecules and their oxidation products were rapidly removed by complexation or electrostatic attraction, followed by coagulation. The use of $\mathrm{NaCl}$ as electrolyte makes feasible the anodic oxidation of $\mathrm{Cl}^{-}$to active chlorine species like $\mathrm{Cl}_{2}, \mathrm{HClO}$ and $\mathrm{ClO}^{-}$, which can oxidize organics in some cases [90].

Rapid decolourization of $25 \mathrm{mg} \mathrm{dm}^{-3}$ of the azo dye Reactive Black 5 in tap water at pH 6.6 in the presence of $2 \mathrm{~g} \mathrm{dm}^{-3} \mathrm{Na}_{2} \mathrm{SO}_{4}$ or $\mathrm{NaCl}$ was achieved using a stirred tank reactor equipped with a $\mathrm{Fe}-\mathrm{SS}$ arrangement [85]. In both cases, the increase in current density accelerated the removal of the dye, more rapidly in chloride than in sulfate medium. After 20 min of EC treatment, $93 \%$ and $82 \%$ of colour removal were found in such media. The authors demonstrated that the decolourization process involved the pre-eminent reduction of the azo bond with cleavage into benzenic and naphthalenic derivatives by $\mathrm{Fe}^{2+}$ compared to the coagulation of the dye with the $\mathrm{Fe}(\mathrm{OH})_{3}$ flocs. Also, an additional effect is observed due to production of $\mathrm{ClO}^{-}$, which oxidize the organic matter but it is dependent on the $\mathrm{pH}$ conditions being less efficient in acidic medium because active chlorine species $\left(\mathrm{Cl}_{2}\right.$ and/or $\mathrm{HClO}$ ) are destroyed by $\mathrm{Fe}^{2+}$ to yield $\mathrm{Fe}^{3+}$ and $\mathrm{Cl}^{-}$. The latter effect 
promotes quicker colour removal at neutral and alkaline media in the presence of chloride than sulfate [85].

As can be seen in Table 3, high percentages of colour removal can be achieved for all dyes effluents by EC, whereas the percentage of COD decay was rather poor in many cases. This different behavior suggests a change in the mechanism of the decolourization process respect to the removal of organics, mainly when azo dyes are treated, as already observed above. While the former can be related to the rapid reductive cleavage of the dye with $\mathrm{Fe}^{2+}$, the latter involved the slower adsorption-desorption of intermediates with $\mathrm{Fe}(\mathrm{OH})_{3}$.

Several comparative EC studies with $\mathrm{Fe}$ and $\mathrm{Al}$ anodes have been performed for synthetic Reactive Red 43 [285] and Crystal Violet [268] dyes used in the textile industry. For these kinds of dyes, selected data of Table 3 showed that the use of $\mathrm{Fe}$ is advantageous compared to $\mathrm{Al}$ for colour removal. The superiority of Fe in most cases can be related to the reduction of dyes by $\mathrm{Fe}^{2+}$ ions supplied to the medium, a fact that not takes place using $\mathrm{Al}$ since dyes are only removed by pure adsorption and coagulation [85]. However, the decay of the colour was significantly influenced by the anions in solution, for example, when $1.8 \mathrm{~L}$ of $50 \mathrm{mg} / \mathrm{L}$ of Reactive Red 43 in the presence of several common anions at neutral $\mathrm{pH}$ were treated employing $\mathrm{Al}-\mathrm{Al}$ electrodes by applying $2.5 \mathrm{~mA} \mathrm{~cm}^{-2}$ [285]. High percentages of colour removal were achieved in the presence of $\mathrm{Cl}^{-}$, which decreased considerably by raising $\mathrm{Cl}^{-}$ content and adding $\mathrm{NO}_{3}{ }^{-}$and $\mathrm{SO}_{4}{ }^{2-}$ owing to the inhibition of $\mathrm{Al}^{3+}$ formed. Similar tests in a Fe-Fe cell revealed that the presence of $\mathrm{NO}_{3}{ }^{-}$ caused a passive layer on the iron anode surface, which was destroyed by pitting corrosion when $\mathrm{Cl}^{-}$was added.

Comparative studies in the existing literature have demonstrated that this procedure is an easy, fast, effective and economical method for achieving almost total elimination of colour of chloride dyes wastewaters with both, $\mathrm{Fe}$ and $\mathrm{Al}$ anodes. In this process, reduction with $\mathrm{Fe}^{2+}$ and/or oxidation with active chlorine species $\left(\mathrm{Cl}_{2} / \mathrm{HClO} / \mathrm{ClO}^{-}\right)$ can play a significant role, apart from coagulation. In contrast, partial destruction of dyes by the above species and/or desorption of byproducts is related to the poor decontamination, in many cases.

Natural organic matter (NOM) was also treated by EC approach. NOM concentrations are frequently lower and natural or ground waters were used as real samples to verify the effectiveness of the electrochemical technology. Efficiencies ranging from 90 to $99 \%$ were generally achieved, however, in some cases, the efficacy of the EC treatment decreased because of the conductivity of the real effluent avoid the efficient implementation of this technique [148,211,296-299].

In the case of pesticides, these organic pollutants were treated by peroxi-EC treatment $[31,119,130,131]$. Fe-ADE arrangement of electrodes was mainly used in $0.05 \mathrm{M}$ of $\mathrm{Na}_{2} \mathrm{SO}_{4}$ with an addition of $\mathrm{H}_{2} \mathrm{O}_{2}$ to promote the electro-chemical reactions in the bulk of solution. Higher efficiencies (100\%) of organic compound removal were achieved in all cases by applying lower current densities $\left(10 \mathrm{~mA} \mathrm{~cm}^{-2}\right)$ under acidic conditions ( $\mathrm{pH} 3$ ), in short times of EC treatment, approximately $40 \mathrm{~min}$. However, DOC decays ranging from $35 \%$ to $66 \%$ at 40 min of treatment, for this reason, the EC was extended up to 120 or 360 min in many cases, obtaining $>85 \%$ of DOC removal. MP-P reactor was frequently used, and the concentration of the pesticides varied from 186 to $270 \mathrm{mg} / \mathrm{L}$.

\subsection{Actual effluents}

Obviously, the main goal of EC technologies consists in their application to actual effluents. Several authors have been dealing during the last years with the treatment of actual industrial effluents. Table 4 summarizes the promising results reported applying EC technologies to depollute different environmental problematic effluents. Different kind of wastewaters have been treated by EC approaches, obtaining several removal efficiencies in terms of an specific organic compound or in terms of colour, COD and DOC, such as almond industry [300], baker's yeast wastewater [301,302], bilge water [303], biodiesel wastewater
[304,305], carwash wastewaters [306], cheese whey wastewater [111], chemical mechanical polishing (CMP) wastewater [307-310], cigarette industry wastewater [311], coal seam water [312], cookies and pasta processing wastewater [128], dairy effluents [313-315], distillery effluent [316-321], domestic wastewater [322]; dyebath effluent [323], egg processing wastewater [324], food-processing wastewater [325], gelatin production effluent [326], hospital operation theatre effluent [327], industrial wastewater [328,329], landfill leachate [330-334], laundry wastewater $[101,103,335]$, oily bilgewater [336], olive oil mill wastewater [46,337-339], olive packaging industry [340], paint manufacturing industry [341], palm oil mill wastewater [342], paper industry black liquor [343], paper industry bleaching effluent [344], paper mill effluents [152,209,345,346], petrochemical wastewater [347], petroleum refinery sulfidic spent caustic wastes [348], petroleum refinery wastewater [349], plugboard wastewater [350], potato chips manufacturing [99], pulp mill effluents [351], restaurant wastewater [352], slaughterhouse effluent [353-356], surfactant-aided soilremediation effluents [357], tannery effluent [358-362], textile effluent [29,34,275,363,364], transport container wastewater [365], vegetable oil refinery wastewater [366], wet-spun acrylic fibers manufacturing wastewater [367], yogurt industry wastewater [368] and chemical-mechanical-planarization wastewater [369]. Results clearly demonstrated that EC technologies can be considered as a promising alternative for treating of real wastewaters, obtain significant decontamination efficiencies. However, pre or post treatments are necessary after EC application. In this frame, novel approaches have been proposed considering the combination of EC with other secondary or tertiary treatments in order to obey the environmental legislations to discharge the treated effluents.

\section{Costs and efficiencies estimation}

The operational cost calculations are indispensable to evaluate the viability of EC application, because not only removal efficiencies are of great interest but also the economic impact of this technology application. The total cost of operation (TCO) is the result of the sum of different costs associated to the EC process operation as it is indicated by Eq. (42) [284,370-372].

TCO $=$ Electricity Price $\times$ Energy consumption + Anode Price

$\times$ Electrodes consumption

+ Sludge transportation and disposal cost $\times$ Sludge Generated

+ Chemicals Price $\times$ Chemicals Added + Maintenance cost

+ Depreciation + Labour Cost-Amortization

Obviously, the final TCO depends on the market prices of consumables and sludge management costs as well as the multiple water treatment technologies. However, the parameters that depend per se on the electrochemical treatment are de Electrical Energy Consumption (EEC) and the Electrode Consumption. Conventionally, the EEC is determined by the expression (43):

$\mathrm{EEC}=\frac{\mathrm{EIt}_{\mathrm{EC}}}{\mathrm{V}_{\mathrm{S}}}$

where $\mathrm{E}$ is the electrical potential in $\mathrm{V}$, I the applied current in $\mathrm{A}, \mathrm{t}_{\mathrm{EC}}$ the time of electrolysis or the EC treatment in $\mathrm{h}$ and $\mathrm{V}_{\mathrm{S}}$ the volume treated in $\mathrm{m}^{3}$. The EEC express consistently the consumption of power in Wh $\mathrm{m}^{-3}$ or $\mathrm{kWh} \mathrm{m}^{-3}$, units extensively used to evaluate the energy consume by other water technologies. However, other parameters associated with EEC are reported in the literature, such as the specific electrical energy consumption (SEEC). In this case, the energy consumption is not referred to the volume treated by EC, being instead related to the total electrode consumption by Eq. (44).

$\mathrm{SEEC}=\frac{\mathrm{nFE}}{3.6 \times 10^{-3} \mathrm{M}_{\mathrm{w}} \varphi}$ 
where $n$ is the number of electrons consumed in the sacrificial anode oxidation ( $n=2 \mathrm{~mol}$ for $\mathrm{Fe}$ and SS or $n=3 \mathrm{~mol}$ for $\mathrm{Al}), \mathrm{F}$ is de Faraday constant $\left(96,487 \mathrm{C} \mathrm{mol}^{-1}\right), \mathrm{M}_{\mathrm{w}}$ is the molecular weight of the anodic material $\left(M_{w}=55.84 \mathrm{~g} \mathrm{~mol}^{-1}\right.$ for $\mathrm{Fe}$ and $\mathrm{M}_{\mathrm{w}}=26.98 \mathrm{~g} \mathrm{~mol}^{-1}$ for Al$)$ and $\varphi$ the current efficiency which could be determined from expression (45):

$\varphi=\frac{\Delta \mathrm{m}_{\text {exp }}}{\Delta \mathrm{m}_{\text {theo }}}$

where the $\Delta \mathrm{m}_{\text {exp }}$ is the electrodic mass loss during the treatment time and $\Delta \mathrm{m}_{\text {theo }}$ the mass loss expected determinable by the Faraday Law and calculable from Eq. (46):

$\Delta \mathrm{m}_{\text {theo }}=\frac{\mathrm{M}_{\mathrm{W}} \mathrm{It}_{\mathrm{EC}}}{\mathrm{nF}}$

It is important to remark that $\varphi$ could present values over 1.0 or $100 \%$ (if it is expressed in percentage), because the theorical dissolution only takes into account the electrochemical oxidation of the sacrificial anode, nevertheless chemical dissolution processes could also occur as it is stated above. So, efficiencies over $100 \%$ could be possible in highly corrosive environments where the chemical oxidation highly contributes on the sacrificial anodes dissolution.

Other extended expression used for energy consumption is the specific electrical energy consumption referred to the mass of pollutant removed (SEECP), determined from Eq. (47):

$\mathrm{SEECP}=\frac{\mathrm{EIt}_{\mathrm{EC}}}{\mathrm{V}_{\mathrm{S}} \sum\left(\mathrm{YM}_{\mathrm{Pol} .}[\text { Pollutant }]_{0}\right)}$

where $\mathrm{Y}$ is the percentage of removal of each pollutant (expression (48)), $\mathrm{M}_{\text {Pol. }}$ is the molecular weight of the pollutant in $\mathrm{g} \mathrm{mol}^{-1}$, [Pollutant $]_{0}$ is the initial concentration of the pollutant in the solution to treat in $\mathrm{mol} \mathrm{m}^{-3}$ and $\mathrm{m}_{\text {Pol. }}$ is the total mass of pollutant removed during the EC treatment express in $\mathrm{g}$ or $\mathrm{kg}$. This expression is used to evaluate and compare the relative cost for each pollutant removal by EC.

$\mathrm{Y}=\frac{[\text { Pollutant }]_{0}-[\text { Pollutant }]}{[\text { Pollutant }]_{0}} \times 100$

The electrode consumption is the mass of the sacrificial anode dissolved or the mass loss during EC operation. The electrode dissolution depends primordially on the applied current obeying the Faraday law that determines the $\Delta \mathrm{m}_{\text {theo }}$ by using Eq. (46). However, this dissolution can be enhanced or reduced depending on the water matrix. In the presence of oxidants such as $\mathrm{OH}$, active chlorine species and so on, higher dissolution efficiencies (Eq. (45)) can be expected, depending mainly on the $\mathrm{pH}$ condition (acidic or extreme alkaline solutions) as well as the anodes chemical dissolution or corrosion. Moreover, the presence of inhibitors such nitrates or the passivation of the electrodic surface could reduce the efficiency of electrodes dissolution. Thus, the electrodes consumptions can be only estimated by the Faraday Law or aproximately defined for effluents that do not change their composition affecting the water matrix and consequently the EC performance.

\section{Conclusions}

The analysis of available literature points out the validity of the EC approach for the elimination of different pollutants from wastewaters, at lab and pilot plant scale. However, more research efforts are needed to clarify the operating conditions that can be applied in order to scale these methods to industrial level, even when these parameters depends on each specific kind of effluents. Nevertheless, EC approach can be considered more effective than other conventional technologies; even when the mechanism to eliminate the pollutants depends strongly on the nature of the contaminant (heavy metal, organic matter, inorganic species, etc.) as well as the other species present in the effluent.

EC has achieved higher removal efficiencies by using principally $\mathrm{Fe}$ or $\mathrm{Al}$ anodes being considered an economical technology. This electrochemical technology is able to reduce high pollutants contents considerably, although it does not achieve complete removal, in some cases. Otherwise, the use of alternative materials as sacrificial anodes has been reported for EC approach, such as $\mathrm{Zn}$ and $\mathrm{Cu}$, in order to propose most economical methodologies; nevertheless, more studies are necessary until to effective implementation. On the other hand, research focused to the application of these methods as pre-treatment stage for biological post-treatment to propose more economical coupled methods is being conducted. Furthermore, the alternative use of inexpensive and renewable energies (sunlight or wind power) in EC should also be investigated to make much more attractive eco-sustainable processes in practice.

For the electrochemists and chemical engineers, this work is extremely significant because future advances will include more real applications of EC in the industry that will motivate the substitution of traditional treatment processes by new alternatives. The future for EC applicability is bright. Some engineers are starting to make important contributions to design industrial plants and to start the commercialization of this technology to more industries because it is important to remark that a significant amount of industrial producers of EC systems already exist, thus the commercialization of this technology is already effective, some years ago. The development of the emerging advanced EC processes is of great interest due to the removal efficiency enhancement. Several other complementary EC procedures that can remove with higher efficiencies the pollutants with lower energy requirements or combined/hybrid EC technologies as pre-/posttreatments can be used. Future developments will rely upon the close collaboration of analytical chemists, engineers and electrochemists to ensure effective application and exploitation of these electrochemical technologies for environmental protection.

Although the concept of employing electrical current to dissolve coagulants and generate oxidants in situ has a long history, recently, much progress has been made to elucidate various performance aspects including $\mathrm{pH}$ profiles between electrodes, precipitated solid phases, electrode passivation, and other factors influencing EC performance [9]. However, more work needs to be done since a universal understanding of the nature and composition of precipitated phases based on water chemistry and electrolysis conditions continues to remain elusive as well as the final fate of the slugde produced during the treatment of wastewaters (e.g.: ceramic materials, asphalt, construction applications). Additionally, preliminary cost estimates suggest that EC is competitive to conventional coagulation especially for smaller installations. Importantly, electrochemical treatment does not consume buffering capacity unlike hydrolyzing metal salt coagulants that behave as Brønsted acids. Hence, EC may be suitable for a wide range of water chemistries and eliminates the need to add base to maintain $\mathrm{pH}$ during coagulation (leading to reduced chemical handling and increased process simplicity).

Promising results have obtained when EC is coupled with other water treatment technologies, however, electrode passivation and inconsistent coagulant dosing over long periods of operation continue to limit the real application of EC. More work remains to be done in order to predict the precipitate morphology and composition based on background water chemistry and EC operating conditions. Such knowledge would benefit our understanding of contaminant removal and fouling control by EC and future design of hybrid systems. Further, long-term pilot-scale on-site evaluations for individual applications are necessary to build an empirical database for integrated treatment approaches in parallel and/or serial mode to developing a more detailed understanding of underlying mechanisms and best design practices.

\section{Acknowledgments}

Financial supports from National Council for Scientific and Technological Development (CNPq - 465571/2014-0; CNPq - 446846/ 
2014-7 and CNPq - 401519/2014-7) and FAPESP (2014/50945-4) are gratefully acknowledged. S. Garcia-Segura gratefully acknowledges the post-doctoral grant awarded from PNPD/CAPES.

\section{References}

[1] UNESCO, The United Nations World Water Development Report 4, Volume 1: Managing Water Report Under Uncertainty Risk, (2012).

[2] J. Bratby, Coagulants, Coagulation and Flocculation in Water and Wastewater Treatment, 2nd ed., IWA Publishing, London, 2006, pp. 50-68.

[3] M.M. Emamjomeh, M. Sivakumar, Review of pollutants removed by electrocoagulation and electrocoagulation/flotation processes, J. Environ. Manag. 90 (2009) 1663-1679.

[4] E. Butler, Y.-T. Hung, R.-L. Yeh, M. Suleiman Al Ahmad, Electrocoagulation in Wastewater Treatment, WaterSA 3 (2011) 495-525.

[5] V. Kuokkanen, T. Kuokkanen, J. Rämö, U. Lassi, Recent applications of electrocoagulation in treatment of water and wastewater-a review, Green Sustain. Chem. 3 (2013) 89-121.

[6] V. Khandegar, A.K. Saroha, Electrocoagulation for the treatment of textile industry effluent - a review, J. Environ. Manag. 128 (2013) 949-963.

[7] O. Sahu, B. Mazumdar, P.K. Chaudhari, Treatment of wastewater by electrocoagulation: a review, Environ. Sci. Pollut. Res. 21 (2014) 2397-2413.

[8] V. Kuokkanen, T. Kuokkanen, J. Rämö, U. Lassi, J. Roinen, Removal of phosphate from wastewaters for further utilization using electrocoagulation with hybrid electrodes - techno-economic studies, J. Water Process Eng. 8 (2015) e50-e57.

[9] J.N. Hakizimana, B. Gourich, M. Chafi, Y. Stiriba, C. Vial, P. Drogui, J. Naja, Electrocoagulation process in water treatment: a review of electrocoagulation modeling approaches, Desalination 404 (2017) 1-21.

[10] O.P. Sahu, P.K. Chaudhari, Review on chemical treatment of industrial waste water, J. Appl. Sci. Environ. Manag. 17 (2013) 241-257.

[11] D.J. Pernitsky, J.K. Edzwald, Selection of alum and polyaluminum coagulants: principles and applications, J. Water. Supply Res. Technol. 55 (2006) 121-141.

[12] J.Q. Jiang, The role of coagulation in water treatment, Curr. Opin. Chem. Eng. 8 (2015) 36-44.

[13] A. Matilainen, M. Vepsäläinen, M. Sillanpää, Natural organic matter removal by coagulation during drinking water treatment: a review, Adv. Colloid Interf. Sci. 159 (2010) 189-197.

[14] A.T. Hubbard, Encyclopedia of Surface and Colloid Science, Marcel Decker Inc. New York, 2002.

[15] C.E. Santo, V.J.P. Vilar, C.M.S. Botelho, A. Bhatnagar, E. Kumar, R.A.R. Boaventura, Optimization of coagulation-flocculation and flotation parameters for the treatment of a petroleum refinery effluent from a Portuguese plant, Chem. Eng. J. 183 (2012) 117-123.

[16] C.S. Lee, J. Robinson, M.F. Chong, A review on application of flocculants in wastewater treatment, Process. Saf. Environ. Prot. 92 (2014) 489-508.

[17] W. Balla, A.H. Essadki, B. Gourich, A. Dassaa, H. Chenik, M. Azzi, Electrocoagulation/electroflotation of reactive, disperse and mixture dyes in an external-loop airlift reactor, J. Hazard. Mater. 184 (2010) 710-716.

[18] A.K. Verma, R.R. Dash, P. Bhunia, A review on chemical coagulation/flocculation technologies for removal of colour from textile wastewaters, J. Environ. Manag. 93 (2012) 154-168.

[19] T. Missana, A. Adell, On the applicability of DLVO theory to the prediction of clay colloids stability, J. Colloid Interface Sci. 230 (2000) 150-156.

[20] E. Brillas, C.A. Martínez-Huitle, Decontamination of wastewaters containing synthetic organic dyes by electrochemical methods. An updated review, Appl. Catal. B Environ. 166-167 (2015) 603-643.

[21] G. Chen, Electrochemical technologies in wastewater treatment, Sep. Purif. Technol. 38 (2004) 11-41.

[22] P. Cañizares, C. Jimenez, F. Martínez, C. Saez, M.A. Rodrigo, Study of the electrocoagulation process using aluminum and iron electrodes, Ind. Eng. Chem. Res. 46 (2007) 6189-6195.

[23] W.L. Chou, C.T. Wang, K.Y. Huang, Investigation of process parameters for the removal of polyvinyl alcohol from aqueous solution by iron electrocoagulation, Desalination 251 (2010) 12-19.

[24] R. Kamaraj, S. Vasudevan, Evaluation of electrocoagulation process for the removal of strontium and cesium from aqueous solution, Chem. Eng. Res. Des. 93 (2015) 522-530.

[25] J. Gregory, J. Duan, Hydrolyzing metal salts as coagulants, Pure Appl. Chem. 73 (2001) 2017-2026.

[26] O.T. Can, M. Bayramoglu, M. Kobya, Decolorization of reactive dye solutions by electrocoagulation using aluminum electrodes, Ind. Eng. Chem. Res. 42 (2003) 3391-3396.

[27] M.Y.A. Mollah, P. Morkovsky, J.A. Gomes, M. Kesmez, J. Parga, J. Cocke, Fundamentals, present and future perspectives of electrocoagulation, J. Hazard. Mater. 114 (2004) 522-530.

[28] B. Al Aji, Y. Yavuz, A.S. Koparal, Electrocoagulation of heavy metals containing model wastewater using monopolar iron electrodes, Sep. Purif. Technol. 86 (2012) 248-254.

[29] S.H. Lin, C.F. Peng, Treatment of textile wastewater by electrochemical method, Water Res. 28 (1994) 277-282.

[30] N. Meunier, P. Drogui, C. Montané, R. Hausler, G. Mercier, J.F. Blais, Comparison between electrocoagulation and chemical precipitation for metals removal from acidic soil lechate, J. Hazard. Mater. B137 (2006) 581-590.

[31] E. Brillas, P.L. Cabot, J. Casado, Electrochemical methods for degradation of organic pollutants in aqueous media, in: M.A. Tarr (Ed.), Chemical Degradation Methods for Wastes and Pollutants Environmental and Industrial Applications, Marcel Dekker, New York, 2003, pp. 235-304.

[32] Z. Yang, H. Xu, G. Zeng, Y. Luo, X. Yang, J. Huang, L. Wang, P. Song, The behavio of dissolution/passivation and the transformation of passive films during electrocoagulation: influences of initial $\mathrm{pH}, \mathrm{Cr}(\mathrm{VI})$ concentration and alternating pulsed current, Electrochim. Acta 153 (2015) 149-158.

[33] N. Daneshvar, H. Ashassi-Sorkhabi, A. Tizpar, Decolorization of organge II by electrocoagulation method, Sep. Purif. Technol. 31 (2003) 153-162.

[34] S. Zodi, O. Potier, F. Lapicque, J.P. Leclerc, Treatment of the textile wastewaterss by electrocoagulation: effect of operating parameters on the sludge settling characteristics, Sep. Purif. Technol. 69 (2009) 29-36.

[35] C. Barrera-Díaz, F. Ureña-Nuñez, E. Campos, M. Palomar-Pardavé, M. RomeroRomo, A combined electrochemical-irradiation treatment of highly colored and polluted industrial wastewater, Radiat. Phys. Chem. 67 (2003) 657-663.

[36] M.J. Pearse, Historical use and future development of chemicals for solid-liquid separation in the mineral processing industry, Miner. Eng. 16 (2003) 103-108.

[37] N. Daneshvar, A. Oladegaragoze, N. Djafarzadeh, Decolorization of basic dye solutions by electrocoagulation: an investigation of the effect of operational parameters, J. Hazard. Mater. B129 (2006) 116-122.

[38] A. Gürses, M. Yalçin, C. Doğar, Electrocoagulation of some reactive dyes: a statistical investigation of some electrochemical variables, Waste Manag. 22 (2002) 491-499.

[39] N. Mordishahla, M.A. Behnajady, S. Kooshaiian, Investigation of the effect of different electrode connections on the removal efficiency of Tartrazine from aqueous solutions by electrocoagulation, Dyes Pigments 74 (2007) 249-257.

[40] N. Daneshvar, A.R. Khataee, A.R.A. Ghadim, M.H. Rasoulifard, Decolorization of C.I. Acid Yellow 23 solution by electrocoagulation process: Investigation of operational parameters and evaluation of specific electrical energy consumption, J. Hazard. Mater. 148 (2007) 566-572.

[41] S. Cotillas, J. Llanos, P. Cañizares, S. Mateo, M.A. Rodrigo, Optimization of an integrated electrodisinfection/electrocoagulation process with Al bipolar electrodes for urban wastewater reclamation, Water Res. 47 (2013) 1741-1750.

[42] J. Gregory, J. Duan, Coagulation by hydrolysing metal salts, Adv. Colloid Interf. Sci. 100-102 (2003) 475-502.

[43] M. Kobya, E. Demirbas, O.T. Can, M. Bayramoglu, Treatment of levafix orange textile dye solution by electrocoagulation, J. Hazard. Mater. B132 (2006) 183-188.

[44] S. Vasudevan, J. Lakshmi, Effects of alternating and direct current in electrocoagulation process on the removal of cadmium from water - a novel approach, Sep. Purif. Technol. 80 (2011) 643-651.

[45] R. Kamaraj, P. Ganesan, J. Lakshmi, S. Vasudevan, Removal of copper from wate by electrocoagulation process-effect of alternating current (AC) and direct current (DC), Environ. Sci. Pollut. Res. 20 (2013) 399-412.

[46] A.S. Fajardo, R.F. Rodrigues, R.C. Martins, L.M. Castro, R.M. Quinta-Ferreira, Phenolic wastewaters treatment by electrocoagulation process using $\mathrm{Zn}$ anode, Chem. Eng. J. 275 (2015) 331-341.

[47] H.A. Moreno-Casillas, D.L. Cocke, J.A.G. Gomes, P. Morkovsky, J.R. Parga, E. Peterson, Electrocoagulation mechanism for COD removal, Sep. Purif. Technol, 56 (2007) 204-211.

[48] Z. Zaroual, M. Azzi, N. Saib, E. Chainet, Contribution to the study of electrocoagulation mechanism in basic textile effluent, J. Hazard. Mater. B131 (2006) 73-78.

[49] S. Aoudj, A. Khelifa, N. Drouiche, R. Belkada, D. Miroud, Simultaneous removal of chromium(VI) and fluoride by electrocoagulation-electroflotation: application of a hybrid Fe-Al anode, Chem. Eng. J. 267 (2015) 153-163.

[50] A. De Mello Ferreira, M. Marchesiello, P.X. Thivel, Removal of copper, zinc and nickel presente in natural water containing $\mathrm{Ca}^{2}+$ and $\mathrm{HCO}_{3}{ }^{-}$ions by electrocoagulation, Sep. Purif. Technol. 107 (2013) 109-117.

[51] I. Heidmann, W. Calmano, Removal of Zn(II), Cu(II), Ni(II), Ag(I) and $\mathrm{Cr}(\mathrm{VI})$ present in aqueous solutions by aluminium electrocoagulation, J. Hazard. Mater. 152 (2008) 934-941.

[52] P. Jarvis, B. Jefferson, S.A. Parsons, Characterising natural organic matter flocs, Water Sci. Technol. 4 (2004) 79-87.

[53] S. Chellam, M.A. Sari, Aluminum electrocoagulation as pretreatment during microfiltration of surface water containing NOM: a review of fouling, NOM, DBP, and virus control, J. Hazard. Mater. 304 (2016) 490-501.

[54] A. Bagga, S. Chellam, D.A. Clifford, Evaluation of iron chemical coagulation and electrocoagulation pretreatment for surface water microfiltration, J. Membr. Sci. 309 (2008) 82-93.

[55] N.P. Gamage, S. Chellam, Aluminum electrocoagulation pretreatment reduces fouling during surface water microfiltration, J. Membr. Sci. 379 (2011) 97-105.

[56] N.P. Gamage, J.D. Rimer, S. Chellam, Improvements in permeate flux by aluminum electroflotation pretreatment during microfiltration of surface water, J. Membr. Sci. 411-412 (2012) 45-53.

[57] M.A. Sari, S. Chellam, Surface water nanofiltration incorporating (electro) coagulation-microfiltration pretreatment: fouling control and membrane characterization, J. Membr. Sci. 437 (2013) 249-256.

[58] S.S. Gao, M.A. Du, J.Y. Tian, J.Y. Yang, J.X. Yang, F. Ma, J. Nan, Effects of chloride ions on electro-coagulation-flotation process with aluminum electrodes for algae removal, J. Hazard. Mater. 182 (2010) 827-834.

[59] C.T. Tanneru, S. Chellam, Mechanisms of virus control during iron electrocoagulation-microfiltration of surface water, Water Res. 46 (2012) 2111-2120.

[60] C.T. Tanneru, J. Narayanan, V.R. Hill, S. Chellam, Relative insignificance of virus inactivation during aluminum electrocoagulation of saline waters, Environ. Sci. Technol. 48 (2014) 14590-14598. 
[61] K.L. Dubrawski, M. Fauvel, M. Mohseni, Metal type and natural organic matter source for direct filtration electrocoagulation of drinking water, J. Hazard. Mater. 244 (2013) 135-141.

[62] P. Cañizares, F. Martinez, C. Jimenez, J. Lobato, M.A. Rodrigo, Comparison of the aluminum speciation in chemical and electrochemical dosing processes, Ind. Eng. Chem. Res. 45 (2006) 8749-8756.

[63] J.A.G. Gomes, P. Daida, M. Kesmez, M. Weir, H. Moreno, J.R. Parga, G. Irwin, H. McWhinney, T. Grady, E. Peterson, D.L. Cocje, Arsenic removal by electrocoagulation using combined Al-Fe electrode system and characterization of products, J. Hazard. Mater. B139 (2007) 220-231.

[64] M.G. Kilic, C. Hosten, A comparative study of electrocoagulation and coagulation of aqueous suspensions of kaolinite powders, J. Hazard. Mater. 176 (2010) 735-740.

[65] C.C. Davis, M. Edwards, Coagulation with hydrolyzing metal salts: mechanisms and water quality impacts, Crit. Rev. Environ. Sci. Technol. 44 (2014) 303-347.

[66] T.C. Timmes, H.C. Kim, B.A. Dempsey, Electrocoagulation pretreatment of seawater prior to ultrafiltration: bench-scale applications for military water purification systems, Desalination 249 (2009) 895-901.

[67] D. Lakshmanan, D.A. Clifford, G. Samanta, Ferrous and ferric ion generation during iron electrocoagulation, Environ. Sci. Technol. 43 (2009) 3853-3859.

[68] M. Ben-Sasson, W. Calmano, A. Adin, Iron-oxidation processes in an electroflocculation (electrocoagulation) cell, J. Hazard. Mater. 171 (2009) 704-709.

[69] C.T. Tanneru, J.D. Rimer, S. Chellam, Sweep flocculation and adsorption of viruses on aluminum flocs during electrochemical treatment prior to surface water microfiltration, Environ. Sci. Technol. 47 (2013) 4612-4618.

[70] G. Chen, X. Chen, P.L. Yue, Electrocoagulation and electroflotation of restaurant wastewater, J. Environ. Eng. 126 (2008) 858-863.

[71] T.H. Kim, Ch. Park, E.B. Shin, S. Kim, Decolorization of disperse and reactive dyes by continuous electrocoagulation process, Desalination 150 (2002) 165-175.

[72] S. Vasudevan, J. Lakshmi, G. Sozhan, Effects of alternatin and direct current in electrocoagulation process on the removal of cadmium from water, J. Hazard. Mater. 192 (2011) 26-34.

[73] P. Ganesan, J. Lakshmi, G. Sozhan, S. Vasudevan, Removal of manganese from water by electrocoagulation: adsorption, kinetics and thermodinamics studies, Can. J. Chem. Eng. 91 (2013) 448-458.

[74] M. Kobya, E. Demirbas, M. Sözbir, Decolorisation of aqueous reactive dye Remazol red 3B by electrocoagulation, Color. Technol. 126 (2010) 282-288.

[75] K. Dermentzis, A. Christoforidis, E. Valsamidou, Removal of nickel, coppe, zinc and chromium from synthetic and industrial wastewater by electrocoagulation, Int. J. Environ. Sci. 1 (2011) 697-710.

[76] W. Wan, T.J. Pepping, T. Banerji, S. Chaudhari, D.E. Giammar, Effects of water chemistry on arsenic removal from drinking water by electrocoagulation, Water Res. 45 (2011) 384-392.

[77] A. Thiam, M. Zhou, E. Brillas, I. Sirés, Two-step mineralization of Tartrazine solutions: study of parameters and by-products during the coupling of electrocoagulation with electrochemical advanced oxidation processes, Appl. Catal. B Environ. 150-151 (2014) 116-125.

[78] S. Vasudevan, B.S. Kannan, J. Lakshmi, S. Mohanraj, G. Sozhan, Effects of alternating and direct current in electrocoagulation process on the removal of fluoride from water, J. Chem. Technol. Biotechnol. 86 (2011) 428-436.

[79] M. Eyvaz, M. Kirlaroglu, T.S. Aktas, E. Yuksel, The effects of alternating current electrocoagulation on dye removal from aqueous solutions, Chem. Eng. J. 153 (2009) 16-22.

[80] K.W. Pi, Q. Xiao, H.Q. Zhang, M. Xia, A.R. Gerson, Decolorization of synthetic methyl orange wastewater by electrocoagulation with periodic reversal of electrodes and optimization by RSM, Process. Saf. Environ. Prot. 92 (2014) 796-806.

[81] C.J. Izquierdo, P. Canizares, M.A. Rodrigo, J.P. Leclerc, G. Valentin, F. Lapicque, Effect of the nature of the supporting electrolyte on the treatment of soluble oils by electrocoagulation, Desalination 255 (2010) 15-20.

[82] C.Y. Hu, S.L. Lo, W.H. Kuan, High concentration of arsenate removal by electrocoagulation with calcium, Sep. Purif. Technol. 126 (2014) 7-14.

[83] A.E. Yilmaz, R. Boncukcuoğlu, M.M. Kocakerim, M.T. Yilmaz, C. Paluluoğlu, Boron removal from geothermal waters by electrocoagulation, J. Hazard. Mater. 153 (2008) 146-151.

[84] S. Aoudj, A. Khelifa, N. Drouiche, M. Hecini, H. Hamitouche, Electrocoagulation process applied to wastewater containing dyes from textile industry, Chem. Eng. Process. 49 (2010) 1176-1182.

[85] U.D. Patel, J.P. Ruparelia, M.U. Patel, Electrocoagulation treatment of simulated floor-wash containing reactive black 5 using iron sacrificial anode, J. Hazard. Mater. 197 (2011) 128-136.

[86] J.L. Trompette, H. Vergnes, On the crucial influence of some supporting electrolytes during electrocoagulation in the presence of aluminum electrodes, J. Hazard. Mater. 163 (2009) 1282-1288.

[87] C.H. Huang, L. Chen, C.L. Yang, Effect of anions on electrochemical coagulation for cadmium removal, Sep. Purif. Technol. 65 (2009) 137-146.

[88] C.Y. Hu, S.L. Lo, W.H. Kuan, Effect of co-existing anions on fluoride removal in electrocoagulation (EC) process using aluminium electrodes, Water Res. 37 (2003) 4513-4523.

[89] B. Lin, R. Hu, C. Ye, Y. Li, C. Lin, A study on the initiation of pitting corrosion in carbon steel in chloride-containing media using scannins electrochemical probes, Electrochim. Acta 55 (2010) 6542-6545.

[90] E. Bocos, E. Brillas, M.A. Sanromán, I. Sirés, I. Electrocoagulation, Simply a phase separation technology? The case of bronopol compared to its treatment by EAOPs, Environ. Sci. Technol. 50 (2016) 7679-7686.

[91] J.L. Trompette, H. Vergnes, C. Coufort, Enhanced electrocoagulation efficiency of lyophobic colloids in the presence of ammonium electrolytes, Colloids Surf. A
Physicochem. Eng. Asp. 315 (2008) 66-73.

[92] F.C. Walsh, D. Pletcher, Electrochemical engineering and cell design, in: D. Pletcher, Z.-Q. Tian, D. Williams (Eds.), Developments in Electrochemistry: Science Inspired by Martin Fleischmann, John Wiley \& Sons, Ltd, New York, 2014 pp. 95-111.

[93] A. Vázquez, I. Rodríguez, I. Lázaro, Primary potential and current density distribution analysis: a first approach for designing electrocoagulation reactors, Chem. Eng. J. 179 (2012) 253-261.

[94] N. Mordishahla, M.A. Behnajady, S. Mohammadi-Aghdam, Investigation of the effect of different electrodes and their connections on the removal efficiency of 4 nitrophenol from aqueous solution by electrocoagulation, J. Hazard. Mater. 154 (2008) 778-786.

[95] D. Gosh, H. Solanki, M.K. Purkait, Removal of Fe(II) from tap water by electrocoagulation technique, J. Hazard. Mater. 155 (2008) 135-143.

[96] D. Gosh, C.R. Medhi, M.K. Purkait, Treatment of fluoride containing drinking water by electrocoagulation using monopolar and bipolar electrode connections, Chemosphere 73 (2008) 1393-1400.

[97] M. Kobya, M. Bayramoglu, M. Eyvaz, Techno-economical evaluation of electrocoagulation for the textile wastewater using different electrode connections, J. Hazard. Mater. 148 (2007) 311-318.

[98] M. Kobya, F. Ulu, U. Gebologlu, E. Demirbas, M.S. Oncel, Treatment of potable water containing low concentration of arsenic with electrocoagulation: different connection modes and Fe-Al electrodes, Sep. Purif. Technol. 77 (2011) 283-293.

[99] M. Kobya, H. Hiz, E. Senturk, C. Aydiner, E. Demirbas, Treatment of potato chips manufacturing wastewater by electrocoagulation, Desalination 190 (2006) 201-211.

[100] A.K. Golder, A.N. Samanta, S. Ray, Removal of $\mathrm{Cr}^{3+}$ by electrocoagulation with multiple electrodes: bipolar and monopolar configurations, J. Hazard. Mater. 141 (2007) 653-661.

[101] C.T. Wang, W.L. Chou, Y.M. Kuo, Removal of COD from laundry wastewater by electrocoagulation/electroflotation, J. Hazard. Mater. 161 (2009) 81-86.

[102] A.K. Golder, A.N. Samanta, S. Ray, Trivalent chromium removal by electrocoagulation and characterization of the process sludge, J. Chem. Technol. Biotechnol. 82 (2007) 496-503.

[103] F. Janpoor, A. Torabian, V. Khatibikamal, Treatment of laundry waste-water by electrocoagulation, J. Chem. Technol. Biotechnol. 86 (2011) 1113-1120.

[104] P. Nuñez, H.K. Hansen, S. Aguirre, C. Maureira, Electrocoagulation of arsenic using iron nanoparticles to treat copper mineral processing water, Sep. Purif. Technol. 79 (2011) 285-290.

[105] T.M. Zewail, N.S. Yousef, Chromium ions $\left(\mathrm{Cr}^{6+} \& \mathrm{Cr}^{3+}\right)$ removal from synthetic wastewater by electrocoagulation using vertical expanded Fe anode, J. Electroanal. Chem. 735 (2014) 123-128.

[106] D. Lakshmanan, D.A. Clifford, G. Samanta, Comparative study of arsenic removal by iron using electrocoagulation and chemical coagulation, Water Res. 44 (2010) $5641-5652$.

[107] T.U. Un, A.S. Koparal, U.B. Ogutveren, Fluoride removal from water and wastewater with a bach cylindrical electrode using electrocoagulation, Chem. Eng. J. 223 (2013) 110-115.

[108] E. Lacasa, P. Cañizares, C. Sáez, F.J. Fernández, M.A. Rodrigo, Electrochemical phosphates removal using iron and aluminium electrodes, Chem. Eng. J. 172 (2011) 137-143.

[109] S. Zhang, J. Zhang, W. Wang, F. Li, X. Cheng, Removal of phosphate from landscape water using an electrocoagulation process powered directly by photovoltaic solar modules, Sol. Energy Mater. Sol. Cells 117 (2013) 73-80.

[110] M.M.S.G. Eiband, K.C. De, A. Trindade, K. Gama, J.V.D. Melo, C.A. MartínezHuitle, S. Ferro, Elimination of $\mathrm{Pb}^{2+}$ through electrocoagulation: applicability of adsorptive stripping voltammetry for monitoring the lead concentration during its elimination, J. Electroanal. Chem. 717-718 (2014) 213-218.

[111] T.U. Un, A. Kandemir, N. Erginel, S.E. Ocal, Continuous electrocoagulation of cheese whey wastewater: Na application of response surface methodology, J. Environ. Manag. 146 (2014) 245-250.

[112] S.S. Hamdan, M.H. El-Naas, Characterization of the removal of chromium(VI) from groundwater by electrocoagulation, J. Ind. Eng. Chem. 20 (2014) $2775-2781$.

[113] V.K. Kovatcheva, M.D. Parlapanski, Sono-electrocoagulation of iron hydroxides, Colloids Surf. A Physicochem. Eng. Asp. 149 (1999) 603-608.

[114] P.M. Lakshmi, P. Sivashanmugam, Treatment of oil tanning effluent by electrocoagulation: influence of ultrasound and hybrid electrode on COD removal, Sep. Purif. Technol. 116 (2013) 378-384.

[115] A. Raschitor, C.M. Fernandez, I. Cretescu, M.A. Rodrigo, P. Cañizares, Sono-electrocoagulation of wastewater polluted with Rodamine 6G, Sep. Purif. Technol. 135 (2014) 110-116.

[116] J.L. Clancy, T.M. Hargy, UV inactivation of microorganisms in water - a review, WaterSA 31 (2004) 19-21.

[117] S. Cotillas, J. Llanos, O.G. Miranda, G.C. Díaz-Trujillo, P. Cañizares, M.A. Rodrigo, Coupling UV irradiation and electrocoagulation for reclamation of urban wastewater, Electrochim. Acta 140 (2014) 396-403.

[118] E. Brillas, R. Sauleda, J. Casado, Peroxi-coagulation of aniline in acidic medium using and oxygen diffusion cathode, J. Electrochem. Soc. 144 (1997) 2374-2379.

[119] E. Brillas, B. Boye, M.A. Baños, J.C. Calpe, J.A. Garrido, Electrochemical degradation of chlorophenoxy and chlorobenzoic herbicides in acidic aqueous médium by the peroxi-coagulation method, Chemosphere 51 (2003) 227-235.

[120] A.R. Yazdanbakhsh, M.R. Massoudinegad, S. Eliasi, A.S. Mohammadi, The influence of operational parameters on reduce of azithromycin COD from wastewate using the peroxi-electrocoagulation process, J. Water Process Eng. 6 (2015) 51-57.

[121] E. Brillas, R. Sauleda, J. Casado, Degradation of 4-chlorophenol by 
anodicoxidation,electro-Fenton, photoelectro-fenton and peroxi-coagulation processes, J. Electrochem. Soc. 145 (1998) 759-765.

[122] D. Salari, A. Niaei, A. Khataee, M. Zarei, Electrochemical treatment of dye solution containing C.I. Basic Yellow 2 by the peroxi-coagulation method and modeling of experimental results by artificial neural network, J. Electroanal. Chem. 629 (2009) $117-125$.

[123] S. Vasudevan, An efficient removal of phenol from water by peroxi-electrocoagulation processes, J. Water Process Eng. 2 (2014) 53-57.

[124] E. Brillas, J. Casado, Aniline degradation by electro-Fenton ${ }^{\oplus}$ and peroxi-coagulation processes using a flow reactor for wastewater treatment, Chemosphere 47 (2002) 241-248.

[125] M. Zarei, A. Niaei, D. Salari, A.R. Khataee, Removal of four dyes from aqueous medium by the peroxi-coagulation method using carbon nanotube-PTFE cathode and neural network modeling, J. Electroanal. Chem. 639 (2010) 167-174.

[126] D. Venu, R. Gandhimathi, P.V. Nidheesh, S.T. Ramesh, Treatment of stabilized landfill leachate using peroxicoagulation process, Sep. Purif. Technol. 129 (2014) 64-70.

[127] C. Barrera-Díaz, B. Frontana-Uribe, B. Bilyeu, Removal of organic pollutants in industrial wastewater with na integrated system of copper electrocoagulation and electrogenerated $\mathrm{H}_{2} \mathrm{O}_{2}$, Chemosphere 105 (2014) 160-164.

[128] G. Roa-Morales, E. Campos-Medina, J. Aguilera-Cotero, B. Bilyeu, C. Barrera-Díaz, Aluminum electrocoagulation with peroxide applied to wastewater from pasta and cookie processing, Sep. Purif. Technol. 54 (2007) 124-129.

[129] C.M. Miller, R.L. Valentine, Mechanistic studies of surface catalyzed $\mathrm{H}_{2} \mathrm{O}_{2}$ decomposition and contaminant degradation in the presence of sand, Water Res. 33 (1999) 2805-2816.

[130] B. Boye, M.M. Dieng, E. Brillas, Electrochemical degradation of 2,4,5-trichlorophenoxyacetic acid in aqueous medium by peroxi-coagulation. Effect of $\mathrm{pH}$ and UV light, Electrochim. Acta 48 (2003) 781-790.

[131] B. Boye, E. Brillas, M.M. Dieng, Electrochemical degradation of the herbicide 4chloro-2-, ethylphenoxyacetic acid in aqueous medium by peroxi-coagulation and photoperoxi-coagulation, J. Electroanal. Chem. 540 (2003) 25-34.

[132] S. Farhadi, B. Aminzadeh, A. Torabian, V. Khatibikamal, M.A. Fard, Comparison of COD removal from pharmaceutical wastewater by electrocoagulation, photoelectrocoagulation, peroxi-electrocoagulation and peroxi-photoelectrocoagulation processes, J. Hazard. Mater. 219-220 (2012) 35-42.

[133] S. Garcia-Segura, E. Brillas, Mineralization of the recalcitrant oxalic and oxamic acids by electrochemical advanced oxidation processes using a boron-doped diamond anode, Water Res. 45 (2011) 2975-2984.

[134] M. Al-Shammiri, A. Al-Saffar, S. Bohamad, M. Ahmed, Waste water quality and reuse in irrigation in Kuwait using microfiltration technology in treatment, Desalination 185 (2005) 213-225.

[135] W.B. Yang, N. Cicek, J. Ilg, State-of-the-art of membrane bioreactors: worldwide research and commercial applications in North America, J. Membr. Sci. 270 (2006) 201-211.

[136] E. Iritani, S. Matsumoto, N. Katagiri, Formation and consolidation of filter cake in microfiltration of emulsion-slurry, J. Membr. Sci. 318 (2008) 56-64.

[137] M. Herzberg, D. Berry, L. Raskin, Impact of microfiltration treatment of secondary wastewater effluent on biofouling of reverse osmosis membranes, Water Res. 44 (2010) 167-176.

[138] H.O. Huang, H.H. Cho, K.J. Schwab, J.G. Jacangelo, Effects of magnetic ion exchange pretreatment on low pressure membrane filtration of natural surface water, Water Res. 46 (2012) 5483-5490.

[139] W. Yuan, A.L. Zydney, Humic acid fouling during microfiltration, J. Membr. Sci. 157 (1999) 1-12.

[140] M. Taniguchi, J.E. Kilduff, G. Belfort, Modes of natural organic matter fouling during ultrafiltration, Environ. Sci. Technol. 37 (2003) 1676-1683.

[141] T. Harif, M. Hai, A. Adin, Electroflocculation as potential pretreatment in colloid ultrafiltration, Water Sci. Technol. 6 (2006) 69-78.

[142] P.K. Holt, G.W. Barton, C.A. Mitchell, The future for electrocoagulation as a localised water treatment technology, Chemosphere 59 (2005) 355-367.

[143] M. Ben-Sasson, A. Adin, Fouling mechanisms and energy appraisal in microfiltration pretreated by aluminum-based electroflocculation, J. Membr. Sci. 352 (2010) 86-94.

[144] M. Ben-Sasson, A. Adin, Fouling mitigation by iron-based electroflocculation in microfiltration: mechanisms and energy minimization, Water Res. 44 (2010) 3973-3981.

[145] M. Ben-Sasson, Y.M. Lin, A. Adin, Electrocoagulation-membrane filtration hybrid system for colloidal fouling mitigation of secondary-effluent, Sep. Purif. Technol. 82 (2011) 63-70.

[146] B.T. Zhu, D.A. Clifford, S. Chellam, Comparison of electrocoagulation and chemical coagulation pretreatment for enhanced virus removal using microfiltration membranes, Water Res. 39 (2005) 3098-3108.

[147] V. Mavrov, S. Stamenov, E. Todorova, H. Chmiel, T. Erwe, New hybrid electrocoagulation membrane process for removing selenium from industrial wastewater, Desalination 201 (2006) 290-296.

[148] M. Ben-Sasson, Y. Zidon, R. Calvo, A. Adin, Enhanced removal of natural organic matter by hybrid process of electrocoagulation and dead-end microfiltration, Chem. Eng. J. 232 (2013) 338-345.

[149] C. Escobar, C. Soto-Salazar, M.I. Toral, Optimization of the electrocoagulation process for the removal of copper, lead and cádmium in natural waters and simulated wastewater, J. Environ. Manag. 81 (2006) 384-391.

[150] C.P. Nanseu-Njiki, S.R. Tchamango, P.C. Ngom, A. Darchen, E. Ngameni, Mercury (II) removal from water by electrocoagulation using aluminium and iron electrodes, J. Hazard. Mater. 168 (2009) 1430-1436.

[151] A.H. Mahvi, S.J.A. Ebrahimi, A. Mesdaghinia, H. Gharibi, M.H. Sowlat,
Performance evaluation of a continuous bipolar electrocoagulation/electrooxidation-electroflotation (ECEO-EF) reactor designed for simultaneous removal of ammonia and phosphate from wastewater effluent, J. Hazard. Mater. 192 (2011) $1267-1274$.

[152] M. Uğurlu, The removal of some inorganic compounds from paper mill effluents by the electrocoagulation method, J. Dermatol. Sci. 17 (2004) 85-99.

[153] S.H. Lin, C.L. Wu, Electrochemical removal of nitrite and ammonia for aquaculture, Water Res. 30 (1996) 715-721.

[154] N. Bektaş, S. Öncel, H.Y. Akbulut, A. Dimoglo, Removal of boron by electrocoagulation, Environ. Chem. Lett. 2 (2004) 51-54.

[155] A.E. Yilmaz, R. Boncukcuoğlu, M.M. Kocakerim, An emprirical model for parameters affecting energy consumption in boron removal from boron-containing wastewaters by electrocoagulation, J. Hazard. Mater. 144 (2007) 101-107.

[156] A.E. Yilmaz, R. Boncukcuoğlu, M.M. Kocakerim, A quantitative comparison between electrocoagulation and chemical coagulation for boron removal from boron-containing solution, J. Hazard. Mater. 149 (2007) 475-481.

[157] A.E. Yilmaz, R. Boncukcuoğlu, M.M. Kocakerim, B. Keskinler, The investigation of parameters affecting boron removal by electrocoagulation method, J. Hazard. Mater. B125 (2005) 160-165.

[158] S. Vasudevan, S.M. Sheela, J. Lakshmi, G. Sozhan, Optimization of the process parameters for the removal of boron from drinking water by electrocoagulation - a clean technology, J. Chem. Technol. Biotechnol. 85 (2010) 926-933.

[159] S. Vasudevan, J. Lakshmi, Electrochemical removal of boron from water: adsorption and thermodynamic studies, Can. J. Chem. Eng. 90 (2012) 1017-1026.

[160] S. Vasudevan, J. Lakshmi, G. Sozhan, Electrochemically assisted coagulation for the removal of boron from water using zinc anode, Desalination 310 (2013) $122-129$.

[161] E.H. Ezechi, M.H. Isa, S.R.M. Kutty, A. Yaqub, Boron removal from produced water using electrocoagulation, Process. Saf. Environ. Prot. 92 (2014) 509-514.

[162] M.H. Isa, E.H. Ezechi, Z. Ahmed, S.F. Magram, S.R.M. Kutty, Boron removal by electrocoagulation and recovery, Water Res. 51 (2014) 113-123.

[163] G. Moussavi, F. Majidi, M. Farzadkia, The influence of operational parameters on elimination of cyanide from wastewater using the electrocoagulation process, Desalination 280 (2011) 127-133.

[164] C.L. Yang, R. Dluhy, Electrochemical generation of aluminum sorbent for fluoride adsorption, J. Hazard. Mater. B94 (2002) 239-252.

[165] M.M. Emamjomeh, M. Sivakumar, Fluoride removal by a continuous flow electrocoagulation reactor, J. Environ. Manag. 90 (2009) 1204-1212.

[166] A.H. Essadki, B. Gourich, Ch. Vial, H. Delmas, M. Bennajah, Defluoridation of drinking water by electrocoagulation/electroflotation in a stirred tank reactor with a comparative performance to an external-loop airlift reactor, J. Hazard. Mater. 168 (2009) 1325-1333.

[167] J. Zhu, H. Zhao, J. Ni, Fluoride distribution in electrocoagulation defluoridation process, Sep. Purif. Technol. 56 (2007) 184-191.

[168] M. Bennajah, B. Gourich, A.H. Essadki, Ch. Vial, H. Delmas, Defluoridation of Morocco drinking water by electrocoagulation/electroflottation in an electrochemical external-loop airlift reactor, Chem. Eng. J. 148 (2009) 122-131.

[169] M.M. Emamjomeh, M. Sivakumar, An empirical model for defluoridation by batch monopolar electrocoagulation/flotation (ECF) process, J. Hazard. Mater. B131 (2006) 118-125.

[170] A.H. Essadki, B. Gourich, M. Azzi, Ch. Vial, H. Delmas, Kinetic study of defluoridation of drinking water by electrocoagulation? Electroflotation in a stirred tank reactor and in an external-loop airlift reactor, Chem. Eng. J. 164 (2010) $106-114$.

[171] M. Behbahani, M.R.A. Moghaddam, M. Arami, Techno-economical evaluation of fluoride removal by electrocoagulation process: optimization through response surface methodology, Desalination 271 (2011) 209-218.

[172] M.M. Emamjomeh, M. Sivakumar, A.S. Varyani, Analysis and the understanding of fluoride removal mechanisms by an electrocoagulation/flotation (ECF) process, Desalination 275 (2011) 102-106.

[173] R. Sinha, I. Khazanchi, S. Mathur, Fluoride removal by a continuous flow electrocoagulation reactor from groundwater of Shivdaspura, Int. J. Eng. Res. Appl. 2 (2012) 1336-1341.

[174] M.A. Sandoval, R. Fuentes, J.L. Nava, I. Rodríguez, Fluoride removal from drinking water by electrocoagulation in a continuous filter press reactor coupled to a flocculator and clarifier, Sep. Purif. Technol. 134 (2014) 163-170.

[175] B. Palahouane, N. Drouiche, S. Aoudj, K. Bensadok, Cost-effective electrocoagulation process for the remediation of fluoride from pretreated photovoltaic wastewater, J. Ind. Eng. Chem. 22 (2015) 127-131.

[176] N. Mameri, A.R. Yeddou, H. Lounici, D. Belhocine, H. Grib, B. Bariou, Defluoridation of septentrional sahara water of North Africa by electrocoagulation process using bipolar aluminium electrodes, Water Res. 32 (1998) 1604-1612.

[177] C.Y. Hu, S.L. Lo, W.H. Kuan, Y.D. Lee, Treatment of high fluoride-content wastewater by continuous electrocoagulation-flotation system with bipolar aluminum electrodes, Sep. Purif. Technol. 60 (2008) 1-5.

[178] F. Shen, X. Chen, P. Gao, H. Chen, Electrochemical removal of fluoride ions from industrial wastewater, Chem. Eng. Sci. 58 (2003) 987-993.

[179] C.Y. Hu, S.L. Lo, W.H. Kuan, Y.D. Lee, Removal of fluoride from semiconductor wastewater by electrocoagulation-flotation, Water Res. 39 (2005) 895-901.

[180] C.Y. Hu, S.L. Lo, W.H. Kuan, Effects of the molar ratio of hydroxide and fluoride to $\mathrm{Al}(\mathrm{III})$ on fluoride removal by coagulation and electrocoagulation, J. Colloid Inerf Sci. 283 (2005) 472-476.

[181] V. Khatibikamal, A. Torabian, F. Janpoor, G. Hoshyaripour, Fluoride removal from industrial wastewater using electrocoagulation and its adsorption kinetics, J. Hazard. Mater. 179 (2010) 276-280.

[182] N. Drouiche, S. Aoudj, H. Lounici, M. Drouiche, T. Ouslimane, N. Ghaffour, 
Fluoride removal from pretreated photovoltaic wastewater by electrocoagulation: an investigation of the eefect of operational parameters, Procedia Eng. 33 (2012) 385-391.

[183] A.S. Koparal, U.B. Öütveren, Removal of nitrate from water by electroreduction and electrocoagulation, J. Hazard. Mater. 89 (2002) 83-94.

[184] M.M. Emamjomeh, M. Sivakumar, Denitrification using a monopolar electrocoagulation/flotation (ECF) process, J. Environ. Manag. 91 (2009) 516-522.

[185] N.S. Kumar, S. Goel, Factors influencing arsenic and nitrate removal from drinking water in a continuous flow electrocoagulation (EC) process, J. Hazard. Mater. 173 (2010) 528-533.

[186] M. Malakootian, N. Yousefi, A. Fatehizadeh, Survey efficiency of electrocoagulation on nitrate removal from aqueous solution, Int. J. Environ. Sci. Technol. 8 (2011) 107-114.

[187] T. Yehya, M. Chafi, W. Balla, Ch. Vial, A. Essadki, B. Gourich, Experimental analysis and modeling of denitrification using electrocoagulation process, Sep. Purif. Technol. 132 (2014) 644-654.

[188] K. Govindan, M. Noel, R. Mohan, Removal of nitrate ion from water by electrochemical approaches, J. Water Process Eng. 6 (2015) 58-63.

[189] N. Bektaş, H.Y. Akbulut, H. Inan, A. Dimoglo, Removal of phosphate from aqueous solutions by electro-coagulation, J. Hazard. Mater. 106B (2004) 101-105.

[190] S. Irdemez, N. Demircioğlu, Y.S. Yildiz, Z. Bingül, The effects of current density and phosphate concentration on phosphate removal from wastewater by electrocoagulation using aluminum and iron plate electrodes, Sep. Purif. Technol. 52 (2006) 218-223.

[191] S. Vasudevan, J. Lakshmi, J. Jayaraj, G. Sozhan, Remediation of phosphate-contaminated water by electrocoagulation with aluminium, aluminium alloy and mild steel anodes, J. Hazard. Mater. 164 (2009) 1480-1486.

[192] M. Behbahani, M.R.A. Moghaddam, M. Arami, A comparison between aluminum and iron electrodes on removal of phosphate from aqueous solutions by electrocoagulation process, Int. J. Environ. Res. 5 (2011) 403-412.

[193] N. Tran, P. Drogui, J.F. Blais, G. Mercier, Phosphorous removal from spiked municipal wastewater using either electrochemical coagulation or chemical coagulation as tertiary treatment, Sep. Purif. Technol. 95 (2012) 16-25.

[194] A. Attour, M. Touati, M. Tlili, M. Ben Amor, F. Lapicque, J.P. Leclerc, Influence of operating parameters on phosphate removal from water by electrocoagulation using aluminum electrodes, Sep. Purif. Technol. 123 (2014) 124-129.

[195] M. Murugananthan, G.B. Raju, S. Prabhakar, Removal of sulfide, sulfate and sulfite ions by electro coagulation, J. Hazard. Mater. B109 (2004) 37-44.

[196] T.P. Vu, A. Vogel, F. Kern, S. Platz, U. Menzel, R. Gadow, Characteristics of an electrocoagulation-electroflotation process in separating powdered activated carbon from urban wastewater effluent, Sep. Purif. Technol. 134 (2014) 196-203.

[197] P. Koedrith, H. Kim, J.I. Weon, Y.R. Seo, Toxicogenomic approaches for understanding molecular mechanisms of heacy metal mutagenicity and carcinogenicity, Int. J. Hyg. Environ. Health 216 (2013) 587-598.

[198] P.M. Bennet, P.D. Jepson, R.J. Law, B.R. Jones, T. Kuiken, J.R. Baker, E. Rogan, J.K. Kirkwood, Exposure to heavy metals and infectious disease mortality in harbor porpoises from England and Wales, Environ. Pollut. 112 (2001) 33-40.

[199] P.R. Kumar, S. Chaudhari, K.C. Khilar, S.P. Mahajan, Removal of arsenic from water by electrocoagulation, Chemosphere 55 (2004) 1245-1252.

[200] J.R. Parga, D.L. Cocke, J.L. Valenzuela, J.A. Gomes, M. Kesmez, G. Irwin, H. Moreno, M. Weir, Arsenic removal via electrocoagulation from heavy metal contaminated groundwater in La Comarca Lagunera México, J. Hazard. Mater. B124 (2005) 247-254.

[201] J.R. Parga, D.L. Cocke, V. Valverde, J.A.G. Gomes, M. Kesmez, H. Moreno, M. Weir, D. Mencer, Characterization of electrocoagulation for removal of chromium and arsenic, Chem. Eng. Technol. 28 (2005) 605-612.

[202] P. Zhang, M. Tong, S. Yuan, P. Liao, Transformation and removal of arsenic in groundwater by sequential anodic oxidation and electrocoagulation, J. Contam. Hydrol. 164 (2014) 299-307.

[203] H.K. Hansen, P. Núñez, R. Grandon, Electrocoagulation as a remediation tool for wastewaters containing arsenic, Miner. Eng. 19 (2006) 521-524.

[204] H.K. Hansen, P. Núñez, D. Raboy, I. Schippacasse, R. Grandon, Electrocoagulation in wastewater containing arsenic: comparing different process designs, Electrochim. Acta 52 (2007) 3464-3470.

[205] N. Balasubramanian, T. Kojima, C.A. Basha, C. Srinivasakannan, Removal of arsenic from aqueous solution using electrocoagulation, J. Hazard. Mater. 167 (2009) 966-969.

[206] N. Balasubramanian, T. Kojima, C. Srinivasakannan, Arsenic removal through electrocoagulation: kinetic and statistical modeling, Chem. Eng. J. 155 (2009) 76-82.

[207] J.F. Martínez-Villafañe, C. Montero-Ocampo, A.M. García-Lara, Energy and electrode consumption analysis of electrocoagulation for the removal of arsenic from underground water, J. Hazard. Mater. 172 (2009) 1617-1622.

[208] E. Lacasa, P. Cañizares, C. Sáez, F.J. Fernández, M.A. Rodrigo, Removal of arsenic by iron and aluminium electrochemically assisted coagulation, Sep. Purif. Technol. 79 (2011) 15-19.

[209] S. Zodi, J.N. Louvet, C. Michon, O. Potier, M.N. Pons, F. Lapicque, J.P. Leclerc, Electrocoagulation as a tertiary treatment for paper mill wastewater: removal of non-biodegradable organic pollution and arsenic, Sep. Purif. Technol. 81 (2011) 62-68.

[210] O.J. Flores, J.L. Nava, G. Carreño, E. Elorza, F. Martínez, Arsenic removal from groundwater by electrocoagulation in a pre-pilot-scale continuous filter press reactor, Chem. Eng. Sci. 97 (2013) 1-6.

[211] E. Mohora, S. Rončević, J. Agbaba, A. Tubić, M. Mitić, M. Klašnia, B. Dalmacija, Removal of arsenic from groundwater rich in natural organic matter (NOM) by continuous electrocoagulation/floculation (ECF), Sep. Purif. Technol. 136 (2014)
$150-156$.

[212] M. Pociecha, D. Lestan, Using electrocoagulation for metal and chelant separation from washing solution after EDTA leaching of $\mathrm{Pb}, \mathrm{Zn}$ and $\mathrm{Cd}$ contaminated soil, J. Hazard. Mater. 174 (2010) 670-678.

[213] K. Brahmi, W. Bouguerra, B. Hamrouni, E. Elaloui, M. Loungou, Z. Tlili, Investigation of electrocoagulation reactor design parameters effect on the removal of cádmium from synthetic and phosphate industrial wastewater, Arab. J. Chem. (2015), http://dx.doi.org/10.1016/j.arabjc.2014.12.012.

[214] J. Rodriguez, S. Stopić, B. Friederich, Continuous electrocoagulation treatment of wastewater from copper production, Erzmetall 60 (2007) 81-87.

[215] A. Shafaei, M. Rezayee, M. Arami, M. Nikazar, Removal of $\mathrm{Mn}^{2+}$ ions from synthetic wastewater by electrocoagulation process, Desalination 260 (2010) 23-28.

[216] A. Shafaei, M. Rezaie, M. Nikazar, Evaluation of $\mathrm{Mn}^{2+}$ and $\mathrm{Co}^{2+}$ removal by electrocoagulation: a case study, Chem. Eng. Process. 50 (2011) 1115-1121.

[217] O. Hanay, H. Hasar, Effect of anions on removing $\mathrm{Cu}^{2+}, \mathrm{Mn}^{2+}$ and $\mathrm{Zn}^{2+}$ in electrocoagulation process using aluminum electrodes, J. Hazard. Mater. 189 (2011) 572-576.

[218] E. Gastios, J.N. Hahladakis, E. Gidarakos, Optimization of electrocoagulation (EC) process for the purification of a real industrial wastewater from toxic metals, J. Environ. Manag. 154 (2015) 117-127.

[219] A.K. Golder, A.N. Samanta, S. Ray, Removal of trivalent chromium by electrocoagulation, Sep. Purif. Technol. 53 (2007) 33-41.

[220] Z. Zaroual, H. Chaair, A.H. Essadki, K. El Ass, M. Azzi, Optimizing the removal of trivalent chromium by electrocoagulation using experimental design, Chem. Eng. J. 148 (2009) 488-495.

[221] F. Akbal, S. Camci, Copper, chromium and nickel removal from metal plating wastewater by electrocoagulation, Desalination 269 (2011) 214-222.

[222] F. Akbal, S. Camci, Treatment of metal plating wastewater by electrocoagulation, Environ. Prog. Sustain. Energy 31 (2012) 340-350.

[223] S.K. Verma, V. Khandegar, A.K. Saroha, Removal of chromium from electroplating industry efluente using electrocoagulation, J. Hazard. Toxic. Radioact. Waste 17 (2013) 146-152.

[224] M. Al-Shannag, Z. Al-Qodah, K. Bani-Melhem, M.R. Qtaishat, M. Alkasrawi, Heavy metal ions removal from metal plating wastewater using electrocoagulation: kinetic study and process performance, Chem. Eng. J. 260 (2015) 749-756.

[225] N. Adhoum, L. Monser, N. Bellakhal, J.E. Belgaied, Treatment of electroplating wastewater containing $\mathrm{Cu}^{2+}, \mathrm{Zn}^{2+}$ and $\mathrm{Cr}(\mathrm{VI})$ by electrocoagulation, J. Hazard. Mater. B112 (2004) 207-213.

[226] A.K. Golder, A.K. Chanda, A.N. Samanta, S. Ray, Removal of $\mathrm{Cr}(\mathrm{VI})$ from aqueous solution: Electrocoagulation vs. chemical coagulation, Sep. Sci. Technol. 42 (2007) 2177-2193.

[227] I. Heidmann, W. Calmano, Removal of $\mathrm{Cr}(\mathrm{VI})$ from model wastewaters by electrocoagulation with Fe electrodes, Sep. Purif. Technol. 61 (2008) 15-21.

[228] S. Aber, A.R. Amani-Ghadim, V. Mirzajani, Removal of Cr(VI) from polluted solutions by electrocoagulation: modeling of experimental results using artificial neural network, J. Hazard. Mater. 171 (2009) 484-490.

[229] M.S. Bhatti, A.S. Reddy, A.K. Thukral, Electrocoagulation removal of $\mathrm{Cr}(\mathrm{VI})$ from simulated wastewater using response surface methodology, J. Hazard. Mater. 172 (2009) 839-846.

[230] I. Zongo, J.P. Leclerc, H.A. Marga, J. Wéthé, F. Lapicque, Removal of hexavalent chromium from industrial wastewater by electrocoagulation: a comprehensive comparison of aluminium and iron electrodes, Sep. Purif. Technol. 66 (2009) $159-166$.

[231] T. Ölmez, The optimization of $\mathrm{Cr}(\mathrm{VI})$ reduction and removal by electrocoagulation using response surface methodology, J. Hazard. Mater. 162 (2009) 1371-1378.

[232] E. Keshmirizadeh, S. Yousefi, M.K. Rofouei, An investigation on the new operational parameter effective in $\mathrm{Cr}(\mathrm{VI})$ removal efficiency: a study on electrocoagulation by alternating pulse current, J. Hazard. Mater. 190 (2011) 119-124.

[233] S. Vasudevan, J. Lakshmi, G. Sozhan, Studies on the al-Zn-in-alloy as anode material for the removal of chromium from drinking water in electrocoagulation process, Desalination 275 (2011) 260-268.

[234] M.K.N. Mahmad, M.A.Z.M.R. Rozainym, I. Abustan, N. Baharun, Electrocoagulation Process by Using Aluminium and Stainless Steel Electrodes to Treat Total Chromium, Colour and Turbidity, Procedia Chem. 19 (2016) 681-686.

[235] H. Xu, Z. Yang, G. Zeng, Y. Luo, J. Huang, L. Wang, P. Song, X. Mo, Investigation of $\mathrm{pH}$ evolution with $\mathrm{Cr}(\mathrm{VI})$ removal in electrocoagulation process: proposing a realtime control strategy, Chem. Eng. J. 239 (2014) 132-140.

[236] K. Cheballah, A. Sahmoune, K. Messaoudi, N. Drouiche, H. Lounici, Simultaneous removal of hexavalent chromium and COD from industrial wastewater by bipolar electrocoagulation, Chem. Eng. Process. 96 (2015) 94-99.

[237] H. Xu, Z. Yang, Y. Luo, G. Zeng, J. Huang, L. Wang, P. Song, X. Yang, A novel approach to sustain $\mathrm{Fe} 0$-electrocoagulation for $\mathrm{Cr}(\mathrm{VI})$ removal by optimizing chloride ions, Sep. Purif. Technol. 156 (2015) 200-206.

[238] C.L. Lai, K.S. Lin, Sludge conditioning characteristics of copper chemical mechanical polishing wastewaters treated by electrocoagulation, J. Hazard. Mater. B136 (2006) 183-187.

[239] A.M. Ferreira, M. Marchesiello, P.X. Thivel, Removal of copper, zinc and nickel present in natural water containing $\mathrm{Ca}^{2+}$ and $\mathrm{HCO}_{3}{ }^{-}$ions by electrocoagulation, Sep. Purif. Technol. 107 (2013) 109-117.

[240] S. Vasudevan, J. Lakshmi, R. Kamaraj, G. Sozhan, A critical study on the removal of copper by an electrochemically assisted coagulation: equilibrium, kinetics, and thermodynamics, Asia Pac. J. Chem. Eng. 8 (2013) 162-171.

[241] M. Prica, S. Adamovic, B. Dalmacija, L. Rajic, J. Trickovic, S. Rapajic, M. Becelic Tomin, The electrocoagulation/flotation study: the removal of heavy metals from the waste fountain solution, Process. Saf. Environ. Prot. 94 (2015) 262-273.

[242] H.J. Mansoorian, A.H. Mahvi, A.J. Jafari, Removal of lead and zinc from battery 
industry wastewater using electrocoagulation process: influence of direct and alternating current by using iron and stainless steel rod electrodes, Sep. Purif. Technol. 135 (2014) 165-175.

[243] S. Vasudevan, J. Jayaraj, J. Lakshmi, G. Sozhan, Removal of iron from drinking water by electrocoagulation: adsorption and kinetics studies, Korean J. Chem. Eng. 26 (2009) 1058-1064.

[244] F. Sánchez-Bayo, Comparative acute toxicity of organic pollutants and reference values for crustaceans. I. Branchiopoda, Copepoda and Ostracoda, Environ. Pollut. 139 (2006) 385-420.

[245] Y. Yu, X. Wang, D. Yang, B. Lei, X. Zhang, X. Zhang, Evaluation of human health risks posed by carcinogenic and non-carcinogenic multiple contaminants associated with consumption of fish from Taihu Lake, China, Food Chem. Toxicol. 69 (2014) 86-93.

[246] L. Ho, G. Newcombe, J.P. Croué, Influence of the character of NOM on the ozonation of MIB and geosmin, Water Res. 36 (2002) 511-518.

[247] M. Drosos, M. Ren, F.H. Frimmel, The effect of $\mathrm{NOM}$ to $\mathrm{TiO}_{2}$ : interactions and photocatalytic behavior, Appl. Catal. B Environ. 165 (2015) 328-334.

[248] M.R. Teixeiria, V.S. Sousa, Fouling of nanofiltration membrane: effects of NOM molecular weight and microcystins, Desalination 315 (2013) 149-155.

[249] D. Schmitt, F. Saravia, F.H. Frimmel, W. Schuessles, NOM-facilitated transporto f metal ions in aquifers; importance of complex-dissociation kinetics and colloids formation, Water Res. 37 (2003) 3541-3550.

[250] O.T. Can, M. Bayramoglu, The effect of process conditions on the treatment of benzoquinone solution by electrocoagulation, J. Hazard. Mater. 173 (2010) 731-736.

[251] I. Kabdaşli, B. Vardar, I. Arslan-Alaton, O. Tünay, Effect of dye auxiliaries on color and COD removal from simulated reactive dyebath effluent by electrocoagulation, Chem. Eng. J. 148 (2009) 89-96.

[252] T. Olmez-Hanci, Z. Kartal, I. Arslan-Alaton, Electrocoagulation of commercial naphthalene sulfonates: process optimization and assessment of implementation potential, J. Environ. Manag. 99 (2012) 44-51.

[253] A.S. Fajardo, R.C. Martins, R.M. Quinta-Ferreira, Treatment of a synthetic phenolic mixture by electrocoagulation using $\mathrm{Al}, \mathrm{Cu}, \mathrm{Fe}, \mathrm{Pb}$, and $\mathrm{Zn}$ as anode materials, Ind. Eng. Chem. Res. 53 (2014) 18339-18345.

[254] M.C. Wei, K.S. Wang, C.L. Huang, C.W. Chiang, T.J. Chang, S.S. Lee, S.H. Chang, Improvement of textile dye removal by electrocoagulation with low-cost steel wool cathode reactor, Chem. Eng. J. 192 (2012) 37-44.

[255] E. Pajootan, M. Arami, N.M. Mahmoodi, Binary system dye removal by electrocoagulation from synthetic and real colored wastewaters, J. Taiwan Inst. Chem. Eng. 43 (2012) 282-290.

[256] J.B. Parsa, H.R. Vahidianm, A.R. Soleymani, M. Abbasi, Removal of acid brown 14 in aqueous media by electrocoagulation: optimization parameters and minimizing of energy consumption, Desalination 278 (2011) 295-302.

[257] Y.A. Mollah, S.R. Pathakm, P.K. Patil, M. Vayuvegula, T.S. Agrawal, J.A.G. Gomes, M. Kesmez, D.L. Cocke, Treatment of orange II azo-dye by electrocoagulation (EC) technique in a continuous flow cell using sacrificial iron electrodes, J. Hazard. Mater. B109 (2004) 165-171.

[258] M.Y.A. Mollah, J.A.G. Gomes, K.K. Das, D.L. Cocke, Electrochemical treatment of Orange II dye solution - use of aluminum sacrificial electrodes and floc characterization, J. Hazard. Mater. 174 (2010) 851-858.

[259] M. Chafi, B. Gourich, A.H. Essadki, C. Vial, A. Fabregat, Comparison of electrocoagulation using iron and aluminium electrodes with chemical coagulation for the removal of a highly soluble acid dye, Desalination 281 (2011) 285-292.

[260] N. Daneshvar, H.S. Sorkhabi, M.B. Kasiri, Decolorization of dye solution containing acid red 14 by electrocoagulation with a comparative investigation of different electrode connections, J. Hazard. Mater. B112 (2004) 55-62.

[261] A. Aleboyeh, N. Daneshvar, M.B. Kasiri, Optimization of C.I. Acid Red 14 azo dye removal by electrocoagulation batch process with response surface methodology, Chem. Eng. Prog. 47 (2008) 827-832.

[262] V. Khandegar, A.K. Saroha, Electrochemical treatment of textile effluent containing acid red 131 dye, J. Hazard. Toxic Radioact. Waste 18 (2014) 38-44.

[263] C.L. Yang, J. McGarrahan, Electrochemical coagulation for textile effluent decolorization, J. Hazard. Mater. B127 (2005) 40-47.

[264] M. Kashefialasl, M. Khosravi, R. Marandi, K. Seyyedi, Treatment of dye solution containing colored index acid yellow 36 by electrocoagulation using iron electrodes, Int. J. Environ. Sci. Technol. 2 (2006) 365-371.

[265] K. Govindan, Y. Oren, M. Noel, Effect of dye molecules and electrode material on the settling behavior of flocs in an electrocoagulation induced settling tank reactor (EISTR), Sep. Purif. Technol. 133 (2014) 396-406.

[266] M. Zarei, D. Salari, A. Niaei, A. Khataee, Peroxi-coagulation degradation of C.I. Basic Yellow 2 based on carbon-PTFE and carbon nanotube-PTFE electrodes as cathode, Electrochim. Acta 54 (2009) 6651-6660.

[267] Y.Ş. Yildiz, Optimization of bomaplex red CR-L dye removal from aqueous solution by electrocoagulation using aluminum electrodes, J. Hazard. Mater. 153 (2008) 194-200.

[268] P. Durango-Usuga, F. Guzmán-Duque, R. Mosteo, M.V. Vazquez, G. Peñuela, A. Torres-Palma, Experimental design approach applied to the elimination of crystal violet in water by electrocoagulation with Fe or Al electrodes, J. Hazard. Mater. 179 (2010) 120-126.

[269] Ch. Phalakornkule, S. Polgumhang, W. Tongdaung, Performance of an electrocoagulation process in treating direct dye: batch and continuous upflow processes, World Acad. Sci. Eng. Technol. 3 (2009) 494-499.

[270] S. Zodi, B. Merzouk, O. Potier, F. Lapicque, J.P. Leclerc, Direct red 81 dye removal by a continuous flow electrocoagulation/flotation reactor, Sep. Purif. Technol. 108 (2013) 215-222.

[271] B. Merzouk, B. Gourich, A. Sekki, K. Madani, Ch. Vial, M. Barkaoui, Studies on the decolorization of textile dye wastewater by continuous electrocoagulation process, Chem. Eng. J. 149 (2009) 207-214.

[272] B. Merzouk, M. Yakoubi, I. Zongo, J.-P. Leclerc, G. Paternotte, S. Pontvianne, F. Lapicque, Effect of modification of textile wastewater composition on electrocoagulation efficiency, Desalination 275 (2011) 181-186.

[273] B. Merzouk, B. Gourich, K. Madani, Ch. Vial, A. Sekki, Removal of disperse red dye from synthetic wastewater by chemical coagulation and continuous electrocoagulation. A comparative study, Desalination 272 (2011) 246-253.

[274] Ch. Phalakornkule, S. Polgumhang, W. Tongdaung, B. Karakat, T. Nuyut, Electrocoagulation of blue reactive, red disperse and mixed dyes, and application in treating textile effluent, J. Environ. Manag. 91 (2010) 918-926.

[275] M. Bayramoglu, M. Kobya, O.T. Can, M. Sozbir, Operating cost analysis of electrocoagulation of textile dye wastewater, Sep. Purif. Technol. 37 (2004) 117-125.

[276] A. Alinsafi, M. Khemis, M.N. Pons, J.P. Leclerc, A. Yaacoubi, A. Benhammou, A. Nejmeddine, Electro-coagulation of reactive textile dyes and textile wastewater, Chem. Eng. Process. 44 (2005) 461-470.

[277] A.K. Golder, N. Hridaya, A.N. Samanta, S. Ray, Electrocoagulation of methylene blue and eosin yellowish using mild steel electrodes, J. Hazard. Mater. B127 (2005) 134-140.

[278] M.S. Secula, I. Creţescu, S. Petrescu, An experimental study of índigo carmine removal from aqueous solution by electrocoagulation, Desalination 277 (2011) $227-235$.

[279] M.S. Secula, B. Cagnon, T. Ferreira de Oliveira, O. Chedeville, H. Fauduet, Removal of acid dye from aqueous solutions by electrocoagulation/GAC adsorption coupling: kinetics and electrical operating costs, J. Taiwan Inst. Chem. Eng. 43 (2012) 767-775.

[280] B.K. Körbahti, A. Tanyolaç, Electrochemical treatment of simulated textile wastewater with industrial components and Levafix Blue CA reactive dye: optimization through response surface methodology, J. Hazard. Mater. 151 (2008) $422-431$.

[281] F. Akbal, A. Kuleyin, Decolorization of Levafix Brilliant Blue E-B by electrocoagulation method, Environ. Prog. Sustain. 30 (2011) 29-36.

[282] M.S. Mahmoud, J.Y. Farah, T.E. Farrag, Enhanced removal of methylene blue by electrocoagulation using iron electrodes, Egypt. J. Pet. 22 (2013) 211-216.

[283] I.A. Sengil, M. Özacar, The decolorization of C.I. Reactive Black 5 in aqueous solution by electrocoagulation using sacrificial iron electrodes, J. Hazard. Mater. 161 (2009) 1369-1376.

[284] E. Yuksel, M. Eyvaz, E. Gurbulak, Electrochemical treatment of colour index reactive Orange 84 and textile wastewater by using stainless steel and iron electrodes, Environ. Prog. Sustain. Energy 32 (2013) 60-68.

[285] A.R. Amani-Ghadim, S. Aber, A. Olad, H. Ashassi-Sorkhabi, Optimization of electrocoagulation process for removal of na azo dye using response surface methodology and investigation on the occurence of destructive side reactions, Chem. Eng. Process. 64 (2013) 68-78.

[286] D. Valero, J.M. Ortiz, E. Expósito, V. Montiel, A. Aldaz, Electrocoagulation of a synthetic textile effluent powered by photovoltaic energy without batteries: direct connection behavior, Sol. Energy Mater. Sol. Cells 92 (2008) 291-297.

[287] D.R. Arsand, K. Kümmerer, A.F. Martins, Removal of dexamethasone from aqueous solution and hospital wastewater by electrocoagulation, Sci. Total Environ. 443 (2013) 351-357.

[288] S. Barisci, F. Ulu, M. Sillanpää, A. Dimoglo, Evaluation of flurbiprofen removal from aqueous solution by elecrosynthesized ferrate(VI) ion and electrocoagulation process, Chem. Eng. J. 262 (2015) 1218-1225.

[289] Y.A. Ouaissa, M. Chabani, A. Amrane, A. Bensmaili, Removal of tetracycline by electrocoagulation: kinetic and isotherm modeling through adsorption, J. Environ. Chem. Eng. 2 (2014) 177-184.

[290] E. Yüksel, I.A. Şengil, M. Özacar, The removal of sodium dodecyl sulfate in synthetic wastewater by peroxi-electrocoagulation method, Chem. Eng. J. 152 (2009) 347-353.

[291] W.L. Chou, C.T. Wang, C.W. Hsu, K.Y. Huang, T.C. Liu, Removal of total organic carbon from aqueous solution containing polyvinyl alcohol by electrocoagulation technology, Desalination 259 (2010) 103-110.

[292] K. Mansouri, K. Elsaid, A. Bedoui, N. Bensalah, A. Abdel-Wahab, Application of electrochemically dissolved iron in the removal of tannic acid from water, Chem. Eng. J. 172 (2011) 970-976.

[293] M. Taheri, M.R. Alavi Moghaddam, M. Arami, Optimization of Acid Black 172 decolorization by electrocoagulation using response surface methodology, J. Environ. Health Sci. Eng. 9 (2012) 23.

[294] S. Singh, V.C. Srivastava, I.D. Mall, Multistep optimization and residue disposa study for electrochemical treatment of textile wastewater using aluminum electrode, Int. J. Chem. React. Eng. 11 (2013) 31-46.

[295] S. Singh, V.C. Srivastava, I.D. Mall, Mechanism of dye degradation during elec trochemical treatment, J. Phys. Chem. C 117 (2013) 15229-15240.

[296] E. Mohora, S. Rončević, B. Dalmacija, J. Agbaba, M. Watson, E. Karlović, M. Dalmacija, Removal of natural organic matter and arsenic from water by electrocoagulation/flotation continuous flow reactor, J. Hazard. Mater. 235-236 (2012) 257-264.

[297] M. Vepsäläinen, M. Pulliainen, M. Sillanpää, Effect of electrochemical cell structure on natural organic matter (NOM) removal from surface water through electrocoagulation (EC), Sep. Purif. Technol. 99 (2012) 20-27.

[298] K.L. Dubrawski, M. Mohseni, In-situ identification of iron electrocoagulation speciation and application for natural organic matter (NOM) removal, Water Res. 47 (2013) 5371-5380.

[299] F. Ulu, S. Barišçi, M. Kobya, M. Sillanpää, An evaluation on different origins of natural organic matters using various anodes by electrocoagulation, Chemosphere 125 (2015) 108-114. 
[300] D. Valero, J.M. Ortiz, V. García, E. Expósito, V. Montiel, A. Aldaz, Electrocoagulation of wastewater from almond industry, Chemosphere 84 (2011) 1290-1295.

[301] M. Kobya, S. Delipinar, Treatment of the baker's yeast wastewater by electrocoagulation, J. Hazard. Mater. 154 (2008) 1133-1140.

[302] E. Gengec, M. Kobya, E. Demirbas, A. Akyol, K. Oktor, Optimization of baker's yeast wastewater using response surface methodology by electrocoagulation, Desalination 286 (2012) 200-209.

[303] G.J. Rincón, E.J. La Motta, Simultaneous removal of oil and grease, and heavy metals from artificial bilge water using electro-coagulation/flotation, J. Environ. Manag. 144 (2014) 42-50.

[304] O. Chavalparit, M. Ongwandee, Optimizing electrocoagulation process for the treatment of biodiesel wastewater using response surface methodology, J. Environ. Sci. 21 (2009) 1491-1496.

[305] J.A. Siles, M.C. Gutiérrez, M.A. Martín, A. Martín, Physical-chemical and biomethanization treatments of wastewater from biodiesel manufacturing, Bioresour. Technol. 102 (2011) 6348-6351.

[306] M. Panizza, G. Cerisola, Applicability of electrochemical methods to carwash wastewaters for reuse. Part 2: Electrocoagulation and anodic oxidation integrated process, J. Electroanal. Chem. 638 (2010) 236-240.

[307] C.L. Lai, S.H. Lin, Electrocoagulation of chemical mechanical polishing (CMP) wastewater from semiconductor fabrication, Chem. Eng. J. 95 (2003) 205-211.

[308] C.L. Lai, S.H. Lin, Treatment of chemical mechanical polishing wastewater by electrocoagulation: system performances and sludge settling characteristics, Chemosphere 54 (2004) 235-242.

[309] C.Y. Hu, S.L. Lo, C.M. Li, W.H. Kuan, Treating chemical mechanical polishing (CMP) wastewater by electro-coagulation-flotation process with surfactant, J. Hazard. Mater. A120 (2005) 15-20.

[310] N. Drouiche, N. Ghaffour, H. Lounici, M. Mameri, Electrocoagulation of chemical mechanical polishing wastewater, Desalination 214 (2007) 31-37.

[311] R.S. Bejankiwar, Electrochemical treatment of cigarette industry wastewater: feasibility study, Water Res. 36 (2002) 4386-4390.

[312] G.J. Millar, J. Lin, A. Arshad, S.J. Couperthwaite, Evaluation of electrocoagulation for the pre-treatment of coal seam water, J. Water Process Eng. 4 (2014) 166-178.

[313] I.A. Sengil, M. Özacar, Treatment of dairy wastewaters by electrocoagulation using mild steel electrodes, J. Hazard. Mater. B137 (2006) 1197-1205.

[314] S. Tchamango, C.P. Nanseu-Njiki, E. Ngameni, D. Hadjiev, A. Darchen, Treatment of dairy effluents by electrocoagulation using aluminium electrodes, Sci. Tota Environ. 408 (2010) 947-952.

[315] Y. Yavuz, E. Öcal, A.S. Koparal, Ü.B. Öğütveren, Treatment of dairy industry wastewater by EC and EF processes using hybrid Fe-Al plate electrodes, J. Chem. Technol. Biotechnol. 86 (2011) 964-969.

[316] N. Kannan, G. Karthikeyan, N. Tamilselvan, Compariosn of treatment potential of electrocoagulation of distillery effluent with and without activated Areca catechu nut carbon, J. Hazard. Mater. B137 (2006) 1803-1809.

[317] F. Kirzhner, Y. Zimmels, Y. Shraiber, Combined treatment of highly contaminated winery wastewater, Sep. Purif. Technol. 63 (2008) 38-44.

[318] C. Thakur, V.C. Srivastava, I.D. Mall, Electrochemical treatment of a distillery wastewater: parametric and residue disposal study, Chem. Eng. J. 148 (2009) $496-505$.

[319] B.M. Krishna, U.N. Murthy, B.M. Kumar, K.S. Lokesh, Electrochemical pretreatment of distillery wastewater using aluminum electrode, J. Appl. Electrochem. 40 (2010) 663-673.

[320] J.A. Davila, F. Machuca, N. Marrianga, Treatment of vinasses by electrocoagulation-electroflotation using the Taguchi method, Electrochim. Acta 56 (2011) $7433-7436$.

[321] V. Khandegar, A.K. Saroha, Electrochemical treatment of distillery spent wash using aluminum and iron electrodes, Chin. J. Chem. Eng. 20 (2012) 439-443.

[322] U. Kurt, M.T. Gonullu, F. Ilhan, K. Varinca, Treatment of domestic wastewater by electrocoagulation in a cell with Fe-Fe electrodes, Environ. Eng. Sci. 25 (2008) $153-161$.

[323] I. Arslan-Alaton, I. Kabdaşli, B. Vardar, O. Tünay, Electrocoagulation of simulated reactive dyebath effluent with aluminum and stainless steel electrodes, J. Hazard. Mater. 164 (2009) 1586-1594.

[324] L.J. Xu, B.W. Sheldon, D.K. Larick, R.E. Carawan, Recovery and utilization of useful by-products from egg processing wastewater by electrocoagulation, Pollut. Sci. 81 (2012) 785-792.

[325] C. Barrera-Díaz, G. Roa-Morales, L. Ávila-Córdoba, T. Pavón-Silva, B. Bilyeu, Electrochemical treatment applied to food-processing industrial wastewater, Ind. Eng. Chem. Res. 45 (2006) 34-38.

[326] N.L. Kruthika, S. Karthika, G.B. Raju, S. Prabhakar, Efficacy of electrocoagulation and electrooxidation for the purification of wastewater generated from gelatin production plant, J. Environ. Chem. Eng. 1 (2013) 183-188.

[327] R. Mahajan, V. Khandegar, A.K. Saroha, Treatment of hospital operation theatre effluent by electrocoagulation, Int. J. Chem. Environ. Eng. 4 (2013) 104-107.

[328] Y. Meas, J.A. Ramirez, M.A. Villalon, T.W. Chapman, Industrial wastewaters treated by electrocoagulation, Electrochim. Acta 55 (2010) 8165-8171.

[329] S. Zodi, O. Potier, F. Lapicque, J.P. Leclerc, Treatment of the industrial wastewaters by electrocoagulation: optimization of coupled electrochemical and sedimentation processes, Desalination 261 (2010) 186-190.

[330] X. Li, J. Song, J. Guo, Z. Wang, Q. Feng, Landfill leachate treatment using electrocoagulation, Procedia Environ Sci 10 (2011) 1159-1164.

[331] S. Top, E. Sekman, S. Hoşver, M.S. Bilgili, Characterization and electrocoagulative treatment of nanofiltration concentrate of a full-scale landfill leachate treatment plant, Desalination 268 (2011) 158-162.

[332] F. Bouhezila, M. Hariti, H. Lounici, N. Mameri, Treatment of the OUED SMAR town landfill leachate by an electrochemical reactor, Desalination 280 (2011) 347-353.

[333] M.O. Orkun, A. Kuleyin, Treatment performance evaluation of chemical oxygen demand from landfill leachate by electro-coagulation and electro-Fenton technique, Environ. Prog. Sustain. Energy 31 (2012) 59-67.

[334] C. Ricordel, H. Djelal, Treatment of landfill leachate with high proportion of refractory materials by electrocoagulation: system performances and sludge settling characteristics, J. Environ. Chem. Eng. 2 (2014) 1551-1557.

[335] J. Ge, J. Qu, P. Lei, H. Liu, New bipolar electrodcoagulation-electroflotation process for the treatment of laundry wastewater, Sep. Purif. Technol. 36 (2004) 33-39.

[336] M. Asselin, P. Drogui, S.K. Brar, H. Benmoussa, J.F. Blais, Organics removal in oily bilgewater by electrocoagulation process, J. Hazard. Mater. 151 (2008) 446-455.

[337] H. Inan, A. Dimoglo, H. Simsek, M. Karpuzcu, Olive oil mill wastewater treatment by means of electro-coagulation, Sep. Purif. Technol. 36 (2004) 23-31.

[338] F. Hanafi, O. Assobhei, M. Mountadar, Detoxification and discoloration of Moroccan olive mill wastewater by electrocoagulation, J. Hazard. Mater. 174 (2010) 807-812.

[339] T. Coskun, F. Ilhan, N.M. Demir, E. Debik, U. Kurt, Optimization of energy costs in the pretreatment of olive mill wastewaters by electrocoagulation, Environ. Technol. 33 (2012) 801-807.

[340] P. García-García, A. López-López, J.M. Moreno-Banquero, A. Garrido-Fernández, Treatment of wastewaters from the green table olive packaging industry using electro-coagulation, Chem. Eng. J. 170 (2011) 59-66.

[341] A. Akyol, Treatment of paint manufacturing wastewater by electrocoagulation, Desalination 285 (2012) 91-99.

[342] M.B. Agustin, W.P. Sengpracha, W. Phutdhawong, Electrocoagulation of palm oil mill effluent, Int. J. Environ. Res. Public Health 5 (2008) 177-180.

[343] M. Zaied, N. Bellakhal, Electrocoagulation treatment of black liquor from paper industry, J. Hazard. Mater. 163 (2009) 995-1000.

[344] R. Sridhar, V. Sivakumar, V.P. Immanuel, J.P. Maran, Treatment of pulp and paper industry bleaching effluent by electrocoagulant process, J. Hazard. Mater. 186 (2011) 1495-1502.

[345] M. Uğurlu, A. Gürses, Ç. Doğar, M. Yalçin, The removal of lignin and phenol from paper mill effluents by electrocoagulation, J. Environ. Manag. 87 (2008) 420-428.

[346] R. Katal, H. Pahlavanzadeh, Influence of different combinations of aluminum and iron electrode on electrocoagulation efficiency: application to the treatment of paper mill wastewater, Desalination 265 (2011) 199-205.

[347] A. Dimoglo, H.Y. Akbulut, F. Cihan, M. Karpuzcu, Petrochemical wastewate treatment by means of clean electrochemical technologies, Clean Techn. Environ. Policy 6 (2004) 288-295.

[348] I.B. Hariz, A. Halleb, N. Adhoum, L. Monser, Treatment of petroleum refinery sulfidic spent caustic wastes by electrocoagulation, Sep. Purif. Technol. 107 (2013) 150-157.

[349] M.H. El-Naas, S. Al-Zuhair, A. Al-Lobaney, S. Makhlouf, Assessment of electrocoagulation for the treatment of petroleum refinery wastewater, J. Environ. Manag. 91 (2009) 180-185.

[350] X. Zhao, B. Zhang, H. Liu, F. Chen, A. Li, J. Qu, Transformation characteristics of refractory pollutants in plugboard wastewater by an optimal electrocoagulation and electro-Fenton process, Chemosphere 87 (2012) 631-636.

[351] M. Vepsäläinen, H. Kivisaari, M. Pulliainen, A. Oikari, M. Sillanpää, Removal of toxic pollutants from pulp mill effluents by electrocoagulation, Sep. Purif. Technol. 81 (2011) 141-150.

[352] X. Chen, G. Chen, P.L. Yue, Separation of pollutants from restaurant wastewater by electrocoagulation, Sep. Purif. Technol. 19 (2000) 65-76.

[353] M. Kobya, H. Hiz, E. Senturk, M. Bayramoglu, Treatment of poultry slaughterhouse wastewaters by electrocoagulation, J. Hazard. Mater. B133 (2006) $172-176$.

[354] M. Bayramoglu, M. Kobya, M. Eyvaz, E. Senturk, Technical and economic analysis of electrocoagulation for the treatment of poultry slaughterhouse wastewater, Sep. Purif. Technol. 51 (2006) 404-408.

[355] M. Asselin, P. Drogui, H. Benmoussa, J.F. Blais, Effectiveness of electrocoagulation process in removing organic compounds from slaughterhouse wastewater using monopolar and bipolar electrolytic cells, Chemosphere 72 (2008) 1727-1733.

[356] S. Bayar, Y.Ş. Yildiz, A.E. Yilmaz, Ş. Irdemez, The effect of stirring speed and current density on removal efficiency of poultry slaughterhouse wastewater by electrocoagulation method, Desalination 280 (2011) 103-107.

[357] R. Lopez-Vizcaíno, C. Sáez, P. Cañizares, M.A. Rodrigo, Electrocoagulation of the effluents from surfactante-aided soil-remediation processes, Sep. Purif. Technol. 98 (2012) 88-93.

[358] R.R. Babu, N.S. Bhadrinarayana, K.M.M.S. Begum, N. Anantharaman, Treatment of tannery wastewater by electrocoagulation, J. Univ. Chem. Technol. Metall. 42 (2007) 201-206.

[359] J. Feng, Y. Sun, Z. Zheng, J. Zhang, S. Li, Y. Tian, Treatment of tannery wastewate by electrocoagulation, J. Environ. Sci. 19 (2007) 1409-1415.

[360] F.R. Espinoza-Quiñones, M.M.T. Fornari, A.N. Módenes, S.M. Palácio, F.G. da Silva Jr, N. Szymanski, A.D. Kroumov, D.E.G. Trigueros, Pollutant removal from tannery effluent by electrocoagulation, Chem. Eng. J. 151 (2009) 59-65.

[361] I.A. Şengil, S. Kulaç, M. Özacar, Treatment of tannery liming drum wastewater by electrocoagulation, J. Hazard. Mater. 167 (2009) 940-946.

[362] Y.A. Ouaissa, M. Chabani, A. Amrane, A. Bensmaili, Integration of electro coagulation and adsorption for the treatment of tannery wastewater - the case of an Algerian factory, Rouiba, Procedia Eng. 33 (2012) 98-101.

[363] O.T. Can, M. Kobya, E. Demirbas, M. Bayramoglu, Treatment of the textile wastewater by combined electrocoagulation, Chemosphere 62 (2006) 181-187.

[364] M. Bayramoglu, M. Eyvaz, M. Kobya, Treatment of the textile wastewater by 
electrocoagulation. Economical evaluation, Chem. Eng. J. 128 (2007) 155-161.

[365] S. Kara, Treatment of transport container washing wastewater by electrocoagulation, Environ. Prog. Sustain. Energy 32 (2013) 249-256.

[366] T.U. Un, A.S. Koparal, U.B. Ogutveren, Electrocoagulation of vegetable oil refinery wastewater using aluminum electrodes, J. Environ. Manag. 90 (2009) 428-433.

[367] C. Gong, Z. Zhang, H. Li, D. Li, B. Wu, Y. Sun, Y. Cheng, Electrocoagulation pretreatment of wet-spun acrylic fibers manufacturing wastewater to improve its biodegradability, J. Hazard. Mater. 274 (2014) 465-472.

[368] T.U. Un, E. Ozel, Electrocoagulation of yogurt industry wastewater and the production of ceramic pigments from the sludge, Sep. Purif. Technol. 120 (2013) 386-391.
[369] W. Den, C. Huang, Electrocoagulation for removal of silica nano-particles from chemical-mechanical-planarization wastewater, Colloids Surf. A Physicochem. Eng. Asp. 254 (2005) 81-89.

[370] D. Ghernaout, B. Ghernaout, A. Saiba, A. Boucherit, A. Kellilm, Removal of humic acids by continuous electromagnetic treatment followed by electrocoagulation in batch using aluminium electrodes, Desalination 239 (2009) 295-308.

[371] J. Zhu, F. Wu, X. Pan, J. Guo, D. Wen, Removal of antimony from antimony mine flotation wastewater by electrocoagulation with aluminium electrodes, J. Environ. Sci. 23 (2011) 1066-1071.

[372] Z.V.P. Murthy, S. Parmar, Removal of strontium by electrocoagulation using stainless steel and aluminum electrodes, Desalination 282 (2011) 63-67. 